\title{
NUEVAS ADICIONES AL CATÁLOGO DE LA AUTOBIOGRAFÍA ESPAÑOLA EN LOS SIGLOS XVIII Y XIX (SEGUNDA SERIE)
}

\section{Fernando DURÁN LÓPEZ}

\author{
Universidad de Cádiz
}

En 1997 publiqué una extensa catalogación del género autobiográfico en España durante los siglos XVIII y XIX y dos años más tarde vieron la luz una primera serie de correcciones y adiciones a esa lista ${ }^{1}$. Sobre esa base ya publicada ofrezco ahora al lector interesado una segunda serie de adiciones, que comprende 84 entradas diferentes, de las cuales 31 corresponden a autores ya recogidos con anterioridad y 53 a autores nuevos. Los que ya figuraban en la lista de 1997 se señalan con el número de orden de aquella edición entre corchetes y precedido de un asterisco, tras el número nuevo que les corresponde en la presente catalogación ${ }^{2}$. De esta forma, el número total de autores que se acumulan en esta lista de autobiógrafos españoles nacidos entre 1694 y 1875 asciende a 558. Sin duda, la nómina no está aún cerrada y podrá ser ampliada en futuras ampliaciones, pero de momento paso a presentar lo que ahora publico.

\footnotetext{
${ }^{1}$ Catálogo comentado de la autobiografía española (siglos XVIII y XIX). Madrid: Ollero \& Ramos, Editores, 1997._- «Adiciones al catálogo de la autobiografía española en los siglos XVIII y XIX». Boletín de la Unidad de Estudios Biográficos, 4 (1999), 73-98. Este trabajo de bibliografía crítica correspondía a un proyecto mayor de estudio del género, cuyos resultados formaron mi tesis doctoral, La autobiografía moderna en España: nacimiento y evolución (siglo XVIII y principios del XIX), leída en junio de 2001 bajo la dirección de Alberto González Troyano. La mayor parte de ella está en trámites de publicación, pero algunas secciones ya las he editado, al igual que algunos otros trabajos recientes sobre la autobiografía española: «La autobiografía juvenil de José Cadalso». Revista de Literatura, LXIV, 128 (2002), 437-473.- Tres autobiografías religiosas del siglo XVIII. Sor Gertrudis Pérez Muñoz, Fray Diego José de Cádiz, José Higueras. Cádiz: Servicio de Publicaciones de la Universidad de Cádiz, 2003.- «La autobiografía como fuente histórica: problemas teóricos y metodológicos». Memoria y civilización. Anuario de historia, 5 (2002), 153-187.— «Fuentes autobiográficas españolas para el estudio de la Guerra de la Independencia». En Congreso Internacional: Fuentes documentales para el estudio de la Guerra de la Independencia, Pamplona, 1-3 de febrero de 2001, Francisco Miranda Rubio (coord.), 47-120. Pamplona: Ediciones Eunate - Sociedad de Estudios Históricos de Navarra - Asociación para el Estudio de la Guerra de la Independencia, 2002. Otros varios trabajos similares se citan en los lugares oportunos de este artículo.

${ }^{2}$ Cuando el autor había sido incluido en la primera serie de adiciones se señala con dos asteriscos.
} 
De esos 31 autores repetidos, hay ocho cuyas entradas rehago ahora por entero de nueva planta, y por tanto sustituyen a las entradas antiguas: María Alonso Recio, Juan Calderón, Gallardo de Mendoza, Ramón Montsalvatge, Juan Lucas del Pozo, Francisco de Borja Téllez-Girón, José Villalobos y José de Villanueva y Vigil. En 1997 no había podido consultar sus obras y sólo las recogí por referencias indirectas, a veces no muy correctas; tras localizar ejemplares, amplío sustancialmente los datos. En otros 22 casos, me limito a incluir noticias editoriales nuevas de obras ya recogidas, por haberse publicado recientemente o bien porque en su momento las pasé por alto; estas entradas no sustituyen a las anteriores, sino que han de sumarse a ellas: son las de José Nicolás de Azara, José María Blanco White, Antonio de Capmany, Leandro Fernández de Moratín, Álvaro de Figueroa, José García de León Pizarro, Gertrudis Gómez de Avellaneda, Santiago González Mateo, Lope Antonio de la Guerra y Peña, Benito Hortelano, Gregorio Mayans, Ramón de Mesonero Romanos, Juan Gabriel del Moral, Emilia Pardo Bazán, Domingo Pérez Macías, Simón de Rojas Clemente, Pedro Romero, Martín Sarmiento, José Somoza, José de Viera y Clavijo, Joaquín Lorenzo Villanueva y José Zorrilla. El caso de Sinesio Delgado combina ambas circunstancias: se actualiza la noticia editorial de Mi teatro y se añade referencias a otras memorias distintas.

En lo que respecta a los autores que incluyo ahora por vez primera, hay dos que corresponden al vasto territorio de la autobiografía religiosa por obediencia, que sin duda aún tiene mucho más que dar de sí a poco que se exploren archivos y bibliotecas: las de Mariana Cuñat y Margarita del Espíritu Santo. Del grupo de autobiógrafos espirituales heterodoxos del XIX, también bastante nutrido, se incorpora la extensa y destacable obra de José Hernández-Ardieta.

Igualmente he incluido ocho nuevos manifiestos justificativos de tema políticomilitar, modalidad que, como ya advertía en mi Catálogo de 1997, supone un apartado tan nutrido como difícil de abarcar: los de Antonio Coris y el marqués de Campo Verde se sitúan en el contexto de la Guerra de la Independencia; el de Fermín Campillo y José María Puente en el Trienio; de la primera guerra carlista y sus luchas políticas contemporáneas son los Rafael de Arístegui, Juan Antonio de Llinás y Dionisio Valdés; por último, el de Máximo Navidad tiene como marco la guerra de Cuba en 1869.

Hay otros cuatro textos que se configuran como breves relaciones de servicios, de intenciones más o menos justificativas según los casos y los fines administrativos para los que se escribieron: son los de Sebastián Feringán (primera mitad del XVIII) y de 
Joaquín Jacinto Benayas, Juan Fernández Cañas y Esteban Fernández de León (los tres en el marco de la guerra de 1808 y acontecimientos posteriores).

De esa modalidad tan decimonónica que son las memorias de militares o políticos, es decir, relatos más o menos extensos y con finalidad no exclusivamente apologética, sino testimonial, se incorporan catorce nuevas referencias: la de Antonio de Alós, de la primera mitad del XVIII, es la más antigua hasta ahora registrada en España; sobre la Guerra de la Independencia giran las de José María de Alós (descendiente del anterior), Rafael Arango y Narciso Coll (en la dimensión venezolana de la crisis de 1808); centrado en el Trienio está el relato de Paulino de Lacalle y en la primera guerra carlista los de un anónimo sacerdote aragonés, José María Rendón y Carlos de Vargas; los escritos de Ignacio Monfort y Francisco Cavero apuntan como principal interés al episodio carlista de San Carlos de la Rápita. De otros acontecimientos levantan acta Dionisio Monedero (la guerra de África de 1860), Ángel Fernández de los Ríos (el Sexenio) y Deogracias González Hurtado (la guerra de Filipinas en 1898). Las memorias de Jerónimo Valdés abarcan toda la vida militar de éste durante la primera mitad del XIX.

Hay cinco piezas breves que corresponden a resúmenes autobiográficos. Cuatro de ellos son de tipo intelectual, según diferentes usos de escritura: el de Juan de Iriarte a mediados del XVIII es una vida literaria inacabada en latín; el del músico Fernando Sor se publicó, versionado y extractado en francés en una enciclopedia especializada; los filósofos católicos Gumersindo Laverde y Nicomedes Martín Mateos escribieron noticias personales abreviadas para información de otros eruditos amigos y correligionarios (Martín Mateos escribió para Laverde y Laverde para Menéndez Pelayo). Por fin, el raro caso de José de Rojas es una nota autobiográfica muy formulística y de carácter nobiliario concebida para exaltación de la casta colegial de la Universidad de Salamanca.

Al amplio y fluido campo de lo que ha venido denominándose autobiografía popular, es decir, textos de carácter personal emanados de las clases bajas habitualmente excluidas de la producción literaria escrita, incorporo ahora siete nuevos autores: Matías Calvo escribió su peripecia durante la francesada y Manuel Ayechu la 
suya de la tercera guerra carlista ${ }^{3}$. Las cinco entradas restantes corresponden a campesinos catalanes y proceden de la excelente monografía de Xavier Torres: son Francisco Baulida, Narciso Ciurana, Jaume Galobardes, Isabel Piferrer y Lluís M. Salvador ${ }^{4}$.

Los textos de Francisco Arderíus y Ramón Estrada son episodios sueltos de unas memorias más bien anecdóticas y dispersas. José Borrell, Adelardo Ortiz de Pinedo y Julio Saracíbar elaboraron unas memorias de tipo profesional o temático, dedicadas a acumular sus recuerdos y experiencias de un asunto concreto de sus vidas: la música, la caza deportiva y la actividad del Senado, respectivamente. Por fin, hay otros siete autores que se pueden incluir entre los que escriben autobiografías personales más o menos extensas, a fines del XIX y la primera mitad del XX, abarcando el conjunto de sus vidas y personalidades: Enrique Arias, Ángel María Barcia, Ruperto Chapí, Sinesio Delgado, Arturo Fernández Iglesias, Gervasio Fournier y Juan Moneva.

La disposición y el contenido de las entradas, así como los criterios seguidos para la selección de las obras recogidas, son idénticos a los del Catálogo de 1997 y no vale la pena repetirlos ahora en toda su extensión; sólo se ha modificado el sistema de cita bibliográfica a fin de ajustarlo a las normas de Signa, a cuyo director, el profesor José Romera Castillo, deseo agradecer el haber puesto a mi disposición la revista. Antes de concluir quisiera también expresar mi reconocimiento a algunos amigos y colegas por varias de las noticias ahora recogidas en estas adiciones, que generosamente me comunicaron en su día, o por haberme facilitado algunas publicaciones que me pusieron sobre la pista de otras. Gracias por ello muy en especial a Alberto Gil Novales, y también a Manuel Ravina Martín, Frédéric Prot, Mónica Bolufer Peruga, José María de Jaime Lorén y Ana María Freire.

\footnotetext{
${ }^{3}$ En ese apartado pueden incluirse también las otras autobiografías orales o indirectas que recogió de esa contienda Jaime del Burgo, dentro de las cuales está la de Ayechu (véase la entrada colectiva que abre la lista).

${ }^{4}$ Xavier Torres Sans. Els llibres de família de pagés (segles XVI-XVIII). Memòries de pagés, memòries de mas. Gerona: CCG Edicions - Associació d’història rural de les comarques gironinesInstitut de Llengua i Cultura Catalanes de la Universitat de Girona, 2000. En este libro se recogen muchos más autores de libros de familia, diarios, recuerdos familiares, y egodocumentos en general; sólo he incluido los que sin abuso pueden apropiarse al concepto de autobiografía que manejo (algunos otros podrían también tal vez valer, en función de futuras consultas). Sobre el libro de Torres, véase mi reseña en Cuadernos de Ilustración y Romanticismo, 9 (2001), 235-239.
} 


\section{AA.VV.; COMBATIENTES CARLISTAS}

—Jaime del Burgo. Veteranos de la causa (Relatos y memorias). San Sebastián: Editorial Española, 1939 (XI + 203 pp.). Prólogo de María Isabel Baleztena.

El objetivo de este libro escrito en plena exaltación franquista es rendir homenaje a los viejos combatientes de la tercera guerra carlista y recuperar su memoria histórica en Navarra. Es un curioso antecedente de los libros de entrevistas y autobiografías orales de protagonistas desconocidos de sucesos históricos que proliferaron en la segunda mitad del siglo XX con el auge de la historia social. Lo fue elaborando y escribiendo durante los años anteriores el historiador navarro Jaime del Burgo, que publicó algunos de los trabajos en la prensa, pero en 1936 el original se destruyó en un lance de la guerra civil. Del Burgo dice haberlo reescrito a partir de lo publicado y de sus notas primitivas. Los capítulos, de estilo muy novelado, reproducen conversaciones con los personajes, bien en forma de diálogo, bien alternando con largos tramos en estilo directo; todas atañen a episodios de 1872-1876. No se puede considerar una obra plenamente autobiográfica, ya que el mediador estructura el discurso y no es fiable su uso de las comillas (el lector sospecha que ha ajustado el contenido a sus propias expectativas literarias e ideológicas mucho más de lo que requeriría una mera corrección de estilo), pero vale la pena tomarla en cuenta. Los veteranos son Pedro Echávarri, Silvestra Larramendi (este capítulo se publicó en El Pensamiento Navarro, de Pamplona, el 10III-1933), Higinio Larumbe, Martín Azurmendi y José León Mugarza (esta biografía la reconstruye Jaime del Burgo con documentación y datos de sus parientes, no hay nada autobiográfico). Mención aparte merece el capítulo dedicado a Manuel Ayechu Urrutia, del que hago entrada separada (véase).

\section{2. [*14]. ALONSO RECIO, MARÍA}

(Alcalá de Henares, Madrid, 1695-1752. En el claustro Sor María de San Ignacio. Entró en la orden carmelita descalza en 1722 y permaneció en el mismo convento hasta su muerte, siendo priora.)

_[Relaciones de su vida espiritual a varios confesores.] 
En mi Catálogo de 1997 recogí la escueta alusión de Serrano y Sanz (BAE 270, nº 547) a estos escritos no conservados hoy día. amplio ahora las noticias con su fuente original, la breve biografía que de la monja hizo el P. Joaquín Navarro en $1752^{5}$. Navarro declara seguir para su obra los apuntes sobre la vida de Sor María dejados por su principal confesor, el P. Alejo de Ariza, fruto de su trato personal con ella. En cierto momento se indica que se le ordenó la escritura de una relación de su vida espiritual y se cuenta la lucha interior de la monja para someterse a ese mandato. En la parte final del folleto, Navarro afirma que la relación de sus favores en los primeros ocho años bajo la dirección del P. Ariza (1722-1730) ocupa un volumen de 307 folios; los siguientes diez años, bajo el P. Diego de Cuadros, por cartas, otro volumen de semejante tamaño. En las últimas páginas Navarro recurre a citas literales de esos extensos escritos, que sin duda respondían al género de la autobiografía religiosa por mandato.

\section{ALÓS Y MORA, JOSÉ MARÍA DE}

(Palma de Mallorca, 1765 - Madrid 1844. Militar. Cuarto marqués de Alós. Combatió en Gibraltar en 1779 y en el Rosellón en 1793. En 1808-1809 sirvió con Cuesta y Alburquerque en las principales acciones del centro y alcanzó el grado de general. Gobernador de Ceuta en 1810-1813, de Cádiz en 1813, en 1819-1820 ministro de la guerra, en 1824-1828 capitán general de Baleares. Absolutista.)

—Manuscrito del Excmo. Sr. D. José María de Alós y de Mora a sus hijos D. Luis, D. Antonio y D. José María de Alós y López de Haro. En [Daniel de Alós y Arregui]. Genealogía de la familia Alós. Madrid: Imprenta y Litografía del Depósito de la Guerra, 1887 (148pp.), apéndice 3, 127148.

—En José María de Alós y de Dou. Genealogía de la familia de Alós. Segunda edición. Barcelona: Tipografía de «La Hormiga de Oro», 1911 (426pp.), apéndice XVI, 384-400.

Como su padre y su abuelo (véase la entrada sobre Antonio de Alós y de Rius), este miembro de un antiguo linaje militar escribió una autobiografía para sus hijos, dentro de

\footnotetext{
${ }^{5}$ Carta del P. Doctor Joaquín Navarro de la Compañía de Jesús, Catedrático de Vísperas de la Universidad de Alcalá: a la Madre Ignacia Antonia de San Lucas, antes Superiora, y hoy actual Priora del Religiosísimo Convento de Carmelitas Descalzas, que llaman de la Imagen, de la filiación y obediencia del Serenísimo Señor Real Infante Cardenal, Arzobispo de Toledo. Sobre la vida, y virtudes de la Madre María de San Ignacio, que murió siendo Priora actual del mismo convento. s. l.: s. i., s. a. (7 hs. + 59 pp.). Con censura del Dr. Agustín Gutiérrez de Moya, fechada en Alcalá a 12-VIII-752. La carta de Navarro se fecha al final en Alcalá, 31-III-1752. Ejemplar en BN, VE 313-17.
} 
un sentido de solidaridad familiar y ética castrense. Se firma en Palma de Mallorca en 1I-1828 y se encabeza con un «Amados hijos míos». Comienza con una reflexión sobre los deberes filiales, la vanidad, el temor de Dios y la lealtad al Rey, para finalmente concluir que es un padre sexagenario y cargado de honores «el que os dirige la voz, para manifestaros cuánto vale el hombre en el Estado, si a su noble nacimiento, reúne el honor de las armas y el servicio de su espada» (129). Refiere su vida desde sus primeros pasos en la milicia con seis años, aunque el relato de verdad comienza con la guerra de 1793, antecedida de un patético preámbulo sobre la abominable revolución francesa; el acontecimiento más desarrollado es la Guerra de la Independencia. Lo que peor lleva es la restauración constitucional de 1820, que le ocasionó graves quebrantos y persecuciones. Finalmente les conmina a tomar ejemplo de él y del resto de sus antepasados, a servir a sus monarcas con lealtad ciega y a apartarse de las ideas disolventes del siglo: «Huid, como de una plaga asoladora y pestífera, de las sectas impías de masones conmíseros y demás sociedades reprobadas por la ley» (142), junto a una batería de consejos semejantes, como cumplir siempre con su palabra, guiarse por el honor, etc. Luego coloca, como sus mayores, una colección de máximas y consejos (143-148). La narración se ciñe a sus propios hechos, con particular atención a sus grados, ascensos y recompensas. Dialoga continuamente con sus hijos, únicos lectores que tiene en mente, para distribuir la materia o justificar el contenido. Entremezcla consideraciones morales y comentarios sobre los acontecimientos, siempre desde una ideología muy conservadora que abomina de los liberales. Sin seguir en esto el ejemplo de su abuelo, su estilo es enfático y con pretensiones de excelencia retórica, apenas cumplidas.

\section{ALÓS Y DE RIUS, ANTONIO DE}

(Barcelona 1693 - Barcelona 1780. Militar. Primer marqués de Alós. Peleó en la guerra de Sucesión y en las campañas de Italia por la casa de Borbón. Fue gobernador de plazas levantinas, así como Capitán General y Presidente de la Audiencia de Mallorca.)

—Carta, instrucciones y relación de servicios que el Excmo. Sr. D. Antonio Alós y Rius, marqués de Alós, Gentilhombre de Cámara del Rey de las Dos Sicilias, Teniente General de los Ejércitos 
de S. M. y Capitán General del Ejército y Reino de Mallorca escribió a sus hijos Don José... Don Ramón... y Don Joaquín... Palma: s. i., [1767 ó 1768] (152 pp.).

-Instrucción militar que el Exmo. Sr. D. Antonio de Alós y de Ríus, marqués de Alós, gentilhombre de cámara del Rey de las Dos Sicilias, teniente general de los Reales Ejércitos de S. M. C., capitán general del ejército y reino de Mallorca, y presidente de su real Audiencia, etc. escribió en dicha isla, y dirigió con carta de XIV. de diciembre de MDCCLXVII a sus tres hijos. Don José, entonces teniente coronel de dragones y capitán del regimiento de Almansa, y en el día marqués de Alós, caballero de la orden de Santiago, comendador en ella de Montiel y la Osa, gentilhombre de cámara de S. M. con ejercicio, y teniente general de los Reales Ejércitos, etc. Don Ramón, capitán entonces del mismo regimiento, y actualmente mariscal de campo de los Reales Ejércitos y caballero de dicha orden, etc. Y don Joaquín, capitán de infantería de Aragón, y actualmente coronel de infantería, gobernador militar y político de Valparaíso en la provincia de Chile y caballero de la referida orden, etc. Reimpreso con las licencias necesarias. Barcelona: Imprenta de Manuel Tejero, 1800 (4 hs. +122 pp.) ${ }^{7}$.

-Instrucción militar... En [Daniel de Alós y Arregui]. Genealogía de la familia Alós. Madrid: Imprenta y Litografía del Depósito de la Guerra, 1887 (148 pp.), apéndice 1, 71-118.

-Instrucción militar... En José María de Alós y de Dou. Genealogía de la familia de Alós. Segunda edición. Barcelona: Tipografía de «La Hormiga de Oro», 1911 (426pp.), apéndice VII, $300-331^{8}$.

Se abre con una carta a sus hijos, fechada en el Real Castillo de Palma, a 14-XII1767, donde indica que «cincuenta y siete años de experiencia marcial me han enseñado que en tan honrosa profesión una consumada teórica y la dilatada práctica son hermanas inseparables del valor»; son sus hijos quienes le piden que les instruya con esa experiencia: «apruebo vuestra solicitud. No me incumbe el oficio de historiador, pero satisfago bastantemente vuestro loable deseo, remitiéndoos la adjunta noticia, reducida a lo que he visto y en que he intervenido». El texto desarrolla los epígrafes «Guerra de España» (1-20), «Guerra particular de Cataluña. Años 1713 y 1714» (21-40), «Primera

\footnotetext{
${ }^{6}$ No he llegado a ver ejemplares de esta primera y rara edición, aunque se conservan algunos, al parecer, en las bibliotecas Universitaria de Barcelona, Municipal de Palma, Pública de Palma y Universitaria de Santiago. (Téngase en cuenta que algunos catálogos confunden esta referencia con la de la reedición de 1800.)

${ }^{7}$ Esta edición es más frecuente, la he consultado por uno de los varios ejemplares de la RAH (sg. 13-1910). Aparte del cambio en el título, hubo alguna actualización de datos en notas, pero el texto base parece ser idéntico al original.

${ }^{8}$ Las dos Genealogías... toman el texto completo de 1800. La primera, sin mención de autoría, es obra de uno de los descendientes de la familia, también militar, Daniel de Alós y Arregui (n. 1842), quien escribió la historia de su linaje en forma de diccionario biográfico desde la Edad Media. Años después, su sobrino José María de Alós y Dou, presbítero y genealogista de profesión, amplió sustancialmente la obra, acumulando varios trabajos manuscritos de diversos parientes, y dándole a todo mayor desarrollo y técnica genealógica.
} 
guerra de Sicilia. Año 1719» (41-59), «Guerra de Ceuta. Año 1721» (60), «Conquista de Orán» (61), «Introducción a la conquista de Nápoles y Sicilia. Años 1733 y 1734» (62-64), «Conquista de Nápoles y Sicilia» (65-72), «Segunda guerra de Sicilia» (73-74), «Pase del ejército español desde Nápoles a Lombardía» (75-78), «Guerra de Italia. Año 1741» (79-116). Finaliza con «Instrucciones» (116-122), es decir, consejos morales y prácticos: fe religiosa, lealtad y obediencia total al Rey, a los superiores, Espíritu de entrega, conducta recomendable para la vida militar...

Se trata de unas memorias militares bajo la coartada, habitual en la época, de un relato para educación de sus hijos, no como testimonio histórico ante la opinión pública o la posteridad. El primer capítulo comienza con su precoz incorporación a la milicia, a partir de allí sigue una narración lineal, ceñida a los hechos bélicos, con mucha información. Habla en plural, cuando se refiere colectivamente a su regimiento, y particulariza en singular cuanto le atañe en lo personal. Entremezcla con el relato alguna que otra reflexión didáctica, pero en general se atiene al relato objetivo de las campañas. Sólo en ocasiones incluye episodios que no presenció, disculpándose con diversos argumentos. El estilo está dominado por la presencia de los hijos, a los que interpela, adelantándose a sus dudas y mencionando conversaciones tenidas con ellos. Los destinatarios no son en este caso una convención, sino una presencia activa en cuanto a la forma y al contenido. Es obra de interés, sobre todo por lo precoz en el desarrollo de unas memorias militares sin sombra de elemento justificativo ni siquiera de vanagloria propia, pensadas dentro de la ética familiar y militar del Antiguo Régimen, muy distinta de la del XIX. Son quizá las primeras memorias de ese género escritas —y publicadas_en España ${ }^{9}$.

\section{ALVENTOS, MARQUÉS DE:}

Véase: ROJAS Y CONTRERAS, JOSÉ DE

9 El texto y el ejemplo del primer marqués de Alós se convirtió en un legado familiar. Su primogénito, José de Alós y Bru (1730-1800), dejó también un manuscrito de 1795 para sus hijos, en el que les encomendaba la obra de su padre. (Se edita también en las dos Genealogías...) Son reflexiones sobre su propia carrera militar y otra nueva serie de consejos morales, pero sin desarrollo narrativo. El cuarto marqués, José María de Alós y Mora hizo también su opúsculo autobiográfico (véase su entrada en este mismo artículo). 


\section{ANÓNIMO: SACERDOTE CARLISTA ARAGONÉS}

—[Memorias.] En Julio Martínez Santa-Olalla. «Memorias de un carlista confinado en Menorca (1835-1838)». Revista de Menorca (5 época, Mahón), XX, cuad. IV y V (abril y mayo 1925), 101-120 y 133-154.

El articulista dice que por azar llegó a sus manos las Memorias de un carlista, que edita con una presentación y unas notas finales. Las escribió un sacerdote aragonés confinado en Menorca tras unos disturbios en Zaragoza. El manuscrito comienza en la hoja 12 de un cuaderno numerado hasta la 66, faltan algunas y se añaden cuatro hojas sueltas que corresponden al fin de 1837 y a principios de 1838. Falta el comienzo. Aunque tal vez se basa en un diario y se explica lo que sucedió día a día, el relato se ofrece en forma retrospectiva, por lo que cabe considerarlo unas memorias parciales de la vida del autor. El tema son las vicisitudes personales sufridas como prisionero, contando los intentos de motín, los desplazamientos, los insultos y ataques del populacho. Escribe con tono humorístico y desenvuelto, que le hace fijarse en los detalles cotidianos: «en esta cárcel de San Martín, a pesar de nuestros trabajos procurábamos divertirnos, quitándonos por la mañana la camisa y matando los piojos que cada cual encontraba. Si alguno tenía fortuna de hallar uno grande lo guardaba para jugar, hasta que moría. El juego era, hacer un círculo y ponerlo en medio con otro y el que corría más y salía más pronto, aquél ganaba. [...] Llegó a ser tanta la abundancia que cada día había corridas» (103). No se preocupa por la política, sino por el testimonio humano, con anécdotas, diálogos, etc. Las secciones finales del texto añaden descripciones de tipo costumbrista o casi etnológico de costumbres menorquinas a las que asiste, como la matanza del cerdo, los carnavales...

\section{ARANGO Y NÚÑEZ DEL CASTILLO, RAFAEL}

(La Habana 1788 - La Habana 1850. De una familia de militares y empleados en Cuba, está en el ejército desde 1799. Teniente de artillería desde 1805, capturado por los ingleses, fue canjeado en La Coruña. En abril de 1808 se reúne en Madrid con su 
hermano José ${ }^{10}$ y se incorpora al Parque de Artillería, sublevado el 2 de Mayo. Daoiz murió en sus brazos. Luego estuvo en Bailén y en otras acciones. En 1821 se retiró a La Habana.)

—El Dos de Mayo de 1808. Manifestación de los acontecimientos del Parque de Artillería de Madrid en dicho día, escrita por el Coronel de Caballería Don Rafael de Arango, que entonces era Teniente y Ayudante interino del Real Cuerpo de Artillería y hoy se halla destinado en la isla de Cuba, su patria. Madrid: Imprenta de la Compañía Tipográfica, 1837 (26 pp.).

—Madrid: J. Villeti, 1853 (18 pp. a dos columnas).

—La Habana: Imprenta y encuadernación La Cubana, 1858.

De la primera y rara edición se conservan ejemplares en la Biblioteca del Palacio Real. Se encabeza: «El 2 de mayo de 1808. Manifestación de los acontecimientos del parque de artillería en dicho día». Empieza diciendo que es la heroica defensa del parque de artillería de Madrid su materia, «pero antes de empezar mi relación, es oportuno decir brevemente cuáles son mis títulos para escribir sobre esto; por qué no lo hice en otros tiempos, y qué motivos del día me han estimulado, hasta hacerme prescindir del embarazo de haber de hablar de mí mismo» (3). Resume sus incidencias biográficas y explica que las agitaciones de la guerra no le permitieron redactar un parte de los hechos, luego no quiso escribirlo para que no pareciese que buscaba recompensas por lo que había sido un deber patriótico; el motivo que le mueve ahora es que el Memorial histórico de la artillería española de Ramón de Salas no menciona a todos los oficiales que participaron en la defensa y contiene errores. «Y con estos fundamentos me ha parecido preciso detallar todo lo que sucedió a mi vista en aquel teatro de gloria y desventura» (5). En la p. 6 comienza el relato desde el 1 de mayo en adelante, siguiendo siempre sus propios pasos, en primera persona y con gran viveza. El afán del autor es puramente testimonial, sin elementos justificativos. El manifiesto termina en la p. 24 con una solemne despedida que evoca la inmortal memoria de Daoiz y Velarde. Sigue una «Nota» (24-26) sobre lo que hizo los días siguientes para salvar su vida y seguir la guerra hasta el final.

\footnotetext{
${ }^{10}$ Véase en mi Catálogo de 1997 la entrada correspondiente a José Arango.
} 


\section{ARDERÍUS, FRANCISCO}

(Marino, combatió en la última guerra de Cuba. Teniente de navío, coronel de inválidos en 1918, autor de varios libros sobre política hispanoamericana y hechos de guerra.)

—De mis recuerdos. Narraciones históricas. Madrid: Imp. Hispano-Alemana, 1914 (164 pp. + 2 hs.). Ilustraciones de Martínez Abades. Prólogo de Lorenzo de Miranda.

Tiene una dedicatoria al marqués de Comillas. Es un libro para niños, con narraciones de la vida militar: «He creído y creo hacer un bien, fijando en sus memorias infantiles, hechos históricos que, al par que enaltezcan nuestra conducta patriótica en pasados desastres, lleven a sus almas el interés del heroísmo y el amor a la Marina y su Patrona la Santa Virgen del Carmen» (7). Está escrito en el estilo vivaz y literario, un tanto novelizado con diálogos y descripciones, que predomina en muchas memorias de principios del XX. Consta de varios capítulos que agrupan un manojo de recuerdos, relatos y reflexiones de Arderíus sobre la vida militar y sobre la patria, la mayor parte referidos a la batalla naval de Santiago de Cuba en 1898; hay tres o cuatro que implican una narración autobiográfica, aunque no es una obra modélica en ese terreno, sino más bien un extremo del género. Entraría en esa categoría el segundo capítulo, «La primera comunión y un episodio histórico emocionante» (39-48), que cuenta la batalla de Santiago desde su peripecia personal; también el titulado «Vencedores y vencidos» (8796), sobre cómo fueron tratados los prisioneros españoles por los americanos, contando su periplo como cautivo desde la batalla a la repatriación. «En la vida militar. Algunos consejos» reflexiona sobre las causas de la derrota, que ilustra con un episodio personal con un centinela que se había dormido. «El juicio de Salomón» (145-156) son recuerdos suyos como guardiamarina en el buque escuela Nautilus. «Y... colorín colorao...» es el capítulo final, con una anécdota semejante a la anterior que le tuvo como protagonista en Marsella.

\section{ARIAS Y FERNÁNDEZ VIÑAS, ENRIQUE}

(Luarca, Asturias, 1856-1930. Huérfano desde los seis años, tras pasar penalidades, 
ejerció el oficio de zapatero. De formación autodidacta, se dedica a componer piezas teatrales, poéticas y prosísticas, así como a frecuentar los círculos políticos republicanos de Madrid, donde pasó parte de su vida.)

- Memorias de un novio viejo en sus bodas de oro. Madrid: Imprenta del Instituto Nacional de Sordomudos y de Ciegos, 1924 (238 pp.). Prólogo de Manuel Fernández Rico.

Esta autobiografía es un libro bastante extraño. No posee una estructura evidente, ni apenas epígrafes y el contenido es errático; el autor, además, habla en plural de modestia, lo que, en un escrito autobiográfico, resulta chocante. El texto comienza sin prólogo; en las primeras páginas relata una conversación con Galdós en 1914, en que él propone al gran novelista que: «si fuese usted más joven le entregaríamos un boceto de nuestra vida, en la seguridad que había de hallar usted materia suficiente para uno más de sus gloriosos episodios» (22). Eso parece tener que ver con su decisión de escribir este libro para documentar su pasión por la vida y por la búsqueda del progreso moral. El centro de su evocación son los avatares de su matrimonio, tras cincuenta años de vida en común. El relato empieza en 1862 con la muerte de su padre, que dejó a su familia en la miseria y le obligó a trabajar de zapatero. ...l solo, por su fuerza de voluntad y por deseos de ser algo más, se instruyó en la escritura y la lectura. A los diecisiete años se enamoró y en 1873 se casó. Otros nudos temáticos son sus ímprobas gestiones para eludir el servicio militar y su viaje a Madrid, llevado por su deseo de conocer a Castelar. Desarrolla sus impresiones de la política, las diversiones, la vida madrileña en general; cuenta su iniciación en la literatura, como poeta admirador de Campoamor, y en el teatro, con su ídolo en Echegaray. Se ocupa asimismo de un viaje por toda España y pasa después a una larga disquisición sobre el absentismo escolar, dentro del tono regeneracionista de que hace siempre gala. A partir de este momento las preocupaciones sociales, morales y políticas se apoderan del relato, desde posiciones izquierdistas. Finalmente explaya sus ideas sobre el matrimonio a través de diálogos ficticios entre varias parejas, lo que le ocupa otra buena porción de páginas. En la p. 151 termina el texto, cuyo último tercio se ocupa de estas materias ensayísticas y reflexivas. En la p. 153 hay un «Epílogo» con cinco episodios de su niñez y juventud, sobre viajes, anécdotas, o política. Hay luego varios poemas suyos. Arias escribe mal, casi siempre pretencioso y a menudo pretendidamente sublime, pero en realidad confuso y vacuo, sin 
dejar ver casi nunca un hilo de discurso coherente. Es obra típica de un cierto tipo de autores de esas décadas procedentes de la clase obrera, pero elevados por medio del esfuerzo y el afán de superación, a lo que se añade una gran pasión por la cultura.

\section{ARÍSTEGUI VÉLEZ, RAFAEL DE}

(Jerez de la Frontera, Cádiz, 1794 - Madrid 1863. Conde de Mirasol. En la Armada entre 1809-1827, combatió en la defensa de Veracruz; pasó al ejército de tierra e hizo una rápida carrera en la guerra carlista en el asedio de Bilbao y otras acciones. Fue capitán general de varias regiones y gobernador de Puerto Rico; senador desde 1845 y ministro entre 1851-1852. Sus últimos diez años fue director general de inválidos.)

—El teniente general conde de Mirasol a la Historia. s. l.: s. i., 1843 (118 pp. $)^{11}$.

En mayo de 1837 Arístegui era uno de los altos mandos del ejército que operaba en el Norte, cuando se produjeron graves reproches de corrupción contra la autoridad militar, culpada por los soldados de sus lamentables condiciones de vida; hubo motines, la tropa asesinó a varios generales y a Mirasol casi le ocurre lo mismo en Hernani. Esto motivó un escándalo, su abandono del mando y su retiro temporal a Francia. Su manifiesto justificativo por tales hechos se fecha en Bayona (11-X-1837) y consta de 92 largos párrafos numerados (3-82) y un apéndice documental con 35 piezas (83-118). Comienza explicando que «cuando en 23 de agosto de 1837 dirigí mi voz al público, forzado por las escenas que privaron a S. M. de tantos esclarecidos servidores, ofrecí hacerlo en breve con más extensión, acumulando los documentos que habían de servir para que los hombres imparciales formasen su juicio; y en 11 de octubre del propio año concluí mi tarea en Bayona; pero [...] [aconsejado por amigos] suspendí la publicación que hago ahora después de seis años, con la intención de que sirva de documento a la historia, y de que la explicación de hechos tan importantes, cuyas consecuencias han sido harto feroces y sangrientas, pueda ilustrar la opinión pública, para prevenir la repetición» (3). De aquí en adelante sigue una narración corrida en orden cronológico,

\footnotetext{
${ }^{11}$ Son incorrectas las noticias que dan algunas fuentes sobre una edición de 1837 en Santander (salvo que se trate de un esbozo inicial de su justificación, dado a conocer por otros medios) y otra de 1848. Jaime del Burgo, que sitúa erróneamente la edición santanderina en la Biblioteca General de Navarra, reproduce un largo fragmento del texto relativo a Aviraneta (Bibliografía del siglo XIX. Guerras carlistas, luchas políticas. Pamplona, 1978).
} 
ceñido siempre al rumbo de sus propias acciones. Reproduce documentos, polemiza con sus acusadores, etc., al estilo habitual de este género. El relato llega aproximadamente hasta agosto de 1837.

\section{AYECHU URRUTIA, MANUEL}

(N. en Meoz, Navarra, 1840. Carlista, entró en la guardia civil, en la que estuvo hasta que en 1872 se sumó al ejército de Don Carlos. Fue apresado y juzgado al finalizar la tercera guerra carlista, pero quedó libre.)

- Manuel Ayechu Urrutia. Hechos y padecimientos de su juventud. En Jaime del Burgo. Veteranos de la causa. (Relatos y memorias). San Sebastián: Editorial Española, 1939 (XI + 203 pp.), 59-127.

Jaime del Burgo recogió testimonios orales de carlistas sobre la guerra de 18721876 (véase la entrada $n^{\circ} 1$ de esta misma catalogación). La entrevista con Silvestra Larramendi fue publicada en El Pensamiento Navarro (10-III-1933) y en ella se mencionaba a Manuel Ayechu; Juan Elizalde, sobrino de éste la leyó y, emocionado, preguntó entre los herederos de su tío, que le entregaron sus memorias autógrafas. Elizalde publicó esta noticia en El Pensamiento Navarro (20-IV-1933) y luego se las entregó a Jaime del Burgo, que las valora así: «Es una magnífica exposición de sus penalidades y de sus alegrías durante los años azarosos de la guerra, que no me resigno a silenciar, pues se trata, además, de una autobiografía hecha sin alardes literarios, y sin otro propósito, por parte del autor, que la íntima y particular satisfacción de plasmar en un cuaderno, una vida agitada, llena de episodios heroicos, cual cumple a un caballero carlista, cruzado eterno de un Ideal que nunca muere» (57-58). El capítulo VI del libro reproduce el manuscrito, dividido en siete capítulos, aunque no se aclara si la división es del original ni el grado de intervención del editor. Ayechu escribe en estilo muy llano, casi telegráfico: cuenta su vida como una lista de sucesivos oficios y destinos militares, pero va intercalando noticias familiares y aspectos cotidianos; es muy preciso con las fechas y los datos, lo que tal vez sugiera la existencia de un diario o de una hoja de servicios. Hay una evidente base oral en muchos de los pasajes, ya que el autor trasluce escasa formación intelectual. Aunque el asunto central es la crónica de la guerra, en todo momento se trata de una autobiografía que sigue su trayectoria personal 
de manera circunstanciada, desde el más pequeño e íntimo detalle (su propensión a sufrir diviesos) asta lo más genérico de los sucesos del día. Termina cuando es hecho preso después de la guerra: «Y en este calabozo estamos todos esperando a que la sentencia venga aprobada de Vitoria» (127).

\section{1. [*42]. AZARA, JOSÉ NICOLÁS DE}

—Memorias del ilustrado aragonés José Nicolás de Azara, Gabriel Sánchez Espinosa (ed.). Zaragoza: Institución Fernando el Católico, Diputación de Zaragoza, 2000 (438pp.).

Se trata de una reedición de la tesis doctoral de Gabriel Sánchez Espinosa, publicada en Alemania en 1994. Respecto a la primera versión, ésta ofrece el texto de la segunda y la tercera de las tres memorias políticas de Azara publicadas en 1847, según el manuscrito original conservado en la BN de Madrid, pero al contrario que en 1994 en esta ocasión el texto se da modernizado y sin aparato de variantes. La introducción ha sido también abreviada ${ }^{12}$.

\section{BARCIA Y PAVÓN, ÁNGEL MARÍA DE}

(Córdoba 1841-1927. Sacerdote, pintor y archivero. Estudió arte en Madrid y Roma, participó en exposiciones, pero por oficio se dedicó al cuerpo de archiveros y bibliotecarios. Dirigió, organizó y catalogó la sección de Bellas Artes de la Biblioteca Nacional hasta su jubilación en 1911. Se distinguió también como conferenciante, crítico artístico y predicador.)

—José López de Toro. «Don Ángel Barcia. Fragmentos de su autobiografía inédita», Revista de Archivos, Bibliotecas y Museos, LXV (1958), 513-531.

-Recuerdos complutenses. Introducción, transcripción y notas de Julián Martín Abad. Texto, fotografías y acuarelas del Alcalá del siglo XIX. Alcalá de Henares: Brocar, asociación bibliófila y cultural, 1994 (63 pp., con láminas) ${ }^{13}$.

\footnotetext{
${ }^{12}$ Véase sobre esta edición mi reseña en Cuadernos dieciochistas, 2 (2001), 290-292.

${ }^{13}$ Consta de: introducción (9-12), texto de Barcia (15-36), notas de Martín Abad (39-46) y láminas (algunas en hojas sueltas en una carpetilla fuera de paginación).
} 
Ángel Barcia era un excelente escritor, además de sus otras cualidades profesionales, y acumuló diarios íntimos, cartas, apuntes y dibujos de su devenir cotidiano durante una dilatada vida. En su vejez aprovechó esos materiales para redactar una extensísima obra de recuerdos e impresiones, manuscrito de siete volúmenes bajo el título de Apuntes de mi camino estudiantil, archiveril, etc., etc., etc. 1843-1896 (BN, mss. 21265-71), al que incorporó mucho material gráfico: dibujos, acuarelas y fotografías $^{14}$. De ese escrito sólo se han publicado los dos fragmentos citados, correspondientes al primer tomo, ff. 1-27 (en el libro de 1994) ${ }^{15}$ y 28-44 (en el artículo de 1958).

Lo editado en 1994 se abre con el rótulo «Alcalá de Henares. Agosto de 1864 a Septiembre de 1867. Enero 1874 a Mayo de 1875» y sigue con una lírica descripción del palacio de los arzobispos de Toledo, donde principió la carrera del archivero. «Empecé mi vida oficinesca y me encontré en ella tan dislocado cuanto hombre puede estarlo en el mundo. Todo se me hacía extraño; todo era contrario a mis ideas y modo de ser. Legajos de papelotes de cosas triviales de las que en mi vida me había ocupado ni entendía; compañeros de oficina con los que me parecía imposible hacer liga; la cotidiana encerrona durante seis mortales horas; el apartamiento de todo cuanto olía a Arte y a vida romancesca; y la perspectiva de que aquello iba a durar siempre...» (18). Habla de sus alojamientos, de las personas con las que convivió, del personal del archivo, del tipo de documentos que manejaba... Al final copia algunas cartas cruzadas con colegas. El segundo texto se encabeza «Barcelona 27 de Septiembre 1867 a 12 de Julio de 1871» y se ocupa de sus cuatro años de archivero en la ciudad condal. Hace una descripción de la ciudad y sus gentes muy negativa: «Barcelona, populosa, ruidosa, áspera, extranjeriza, siempre me hubiera repelido; en el tiempo en que me tocó estar en ella, se me hizo intolerable» (525). Por lo demás, la selección de contenidos es idéntica

\footnotetext{
${ }^{14}$ La historia del manuscrito tiene zonas oscuras, según el relato de Martín Abad. López de Toro fue el primero en darlo a conocer parcialmente en 1958, y anunciaba una futura publicación, que no se produjo. En 1977 Enrique Pardo Canalís lo describió con más detalle y con una selección de pasajes en: «Don Ángel María de Barcia». Revista de Ideas Estéticas, 139 (1977), 253-276. Los tomos pertenecían a la BN, a la que los había donado Barcia, pero no se habían catalogado y su divulgación era reservada hasta pasados muchos años de la muerte del autor; al parecer, su custodia la habían asumido personalmente los bibliotecarios de la familia Paz: Antonio Paz Meliá, Julián Paz Espeso y Ramón Paz Remolar. Este último guardó el material hasta que lo devolvió a la Biblioteca en 1981, haciéndose constar entonces que faltaban algunos folios.

${ }^{15}$ Martín Abad añade también otros folios (f. 90 del ms. 21266 y el comienzo del ms. 21267) que se refieren a Alcalá de Henares.
} 
a la del pasaje anterior, aunque ahora su estancia coincidió con la Revolución de 1868, que relata con horror de monárquico, conservador y católico.

Barcia escribe con estilo colorista, nostálgico y buenhumorado, centrándose en sus impresiones personales y en las emociones recuperadas por el recuerdo, añadiendo también sabrosas descripciones de edificios y lugares. Sobresalen los retratos y semblanzas habilísimas de sus compañeros de trabajo: «Romeu, voluminoso, con gravísimo coram vobis, pronunciada fealdad decorativa, y en el ánimo la bondad peculiar de los grandes cetáceos, que se trasparentaba cómicamente a través de una ceremoniosa prosopopeya» (1958: 518). Sin duda, lo mejor, en general, es la brillantez del estilo, excelente visión literaria, emotiva y perspicaz, con que viste sus recuerdos de cosas y personas. Es obra que merecería una edición completa.

\section{BAULIDA MASCORT, FRANCISCO}

(1850 - después de 1887. Artesano en Cassá de la Selva, era hijo de una familia campesina del Bajo Ampurdán, huérfano desde los siete años.)

—Historia de Francisco Baulida Mascort, el Desgraciado, después de la muerte de su padre..., ms. conservado en archivo particular.

Se trata de una «autobiografía e historia familiar» en castellano, según Xavier Torres, redactada hacia 1880, de la que sólo cita este breve pasaje: «creci en la adad que yo me aquerdo me hasian a gardar en ayuda de la criada o minona las obellas y tosinos...».

Bibliogr.: Xavier TORRES SANS. Els llibres de família de pagés (segles XVIXVIII). Memòries de pagés, memòries de mas. Gerona: CCG Edicions - Associació d'història rural de les comarques gironines - Institut de Llengua i Cultura Catalanes de la Universitat de Girona, 2000, 30-31 y apéndice.

\section{BENAYAS, JOAQUÍN JACINTO}

(Hijo de un hacendado de Benavente. Entre 1808-1814, junto con su padre, fue varias veces preso, condenado a muerte y encarcelado por los franceses en Benavente, 
Zamora y Toro. En 1816 obtiene dos beneficios de la Catedral de Lérida. En 1820 es realista y conspira contra los liberales, contra los que se levanta en armas en 1823.)

—Documentos pertenecientes al capitán de caballería retirado D. Joaquín Jacinto Benayas, y servicios hechos personalmente a Su Majestad desde el año de 1808 hasta el de 1823 de su esclavitud. s. l.: s. i., [1823] (12 pp., edición privada).

No hay pie de imprenta en este opúsculo bellamente encuadernado, del que quedan ejemplares en la Biblioteca del Palacio Real (IV-1153) y en BN (2-24405). En la primera página figura un nuevo encabezamiento: Relación de méritos y servicios contraídos en la Guerra pasada, y en los tres años de esclavitud y conspiraciones contra el llamado sistema Constitucional por el Capitán graduado de Caballería, y retirado Don Joaquín Jacinto Benayas. Empieza así: «En el año de 1808, siendo hijo único, y uno de los principales hacendados de la villa de Benavente, le presentó su padre Don Francisco Javier Benayas con caballo y armas al Excmo. Señor Don Gregorio de la Cuesta, Capitán general de Castilla la Vieja, gustoso a que sacrificase su vida en defensa del Rey y de la Patria, como así consta por los documentos presentados...» (3). Se expresa en tercera persona, según es norma en esta clase de escritos oficiales, de redacción concisa y muy selectiva en el contenido. No obstante, expone sus méritos con cierto detalle y expresividad, desde que su madre fue sacada de la casa por los franceses y golpeada hasta descomponerle un brazo, hasta cualquier otro aspecto que avalore su patriotismo. Tiene incluso un cierto estilo patético en ciertos pasajes que le alejan de la frialdad burocrática: «...por último logran asesinar a su padre. Ya no existe este buen vasallo, ya acabó de hacer beneficios en defensa de su idolatrado Monarca, ya queda huérfano de padre y sin su amable compañía el Don Joaquín; su madre errante, sin casa ni domicilio alguno, enfermo, y aún no desmaya, siempre constante en aquellas primeras ideas que le hizo concebir el difunto su padre...» (6). Hasta la p. 8 cuenta lo relativo a la guerra y luego, sin transición, pasa a 1820, declarándose ferviente realista y enumerando sus servicios por la causa. Al fin está la usual indicación de que el impreso se ajusta a los documentos originales, lo que hace constar el empleado de rigor a 30-VII-1823. Es una muestra particularmente lograda de ese subgénero burocrático que es la relación de servicios, del que hay miles en los archivos, pero que sólo en pocas ocasiones vale la pena incluir en un estudio de la autobiografía. 


\section{5. [*65]. BLANCO WHITE, JOSÉ MARÍA}

—Escritos autobiográficos menores, Antonio Garnica Silva (ed. y trad.). Huelva: Universidad de Huelva («Arias Montano», 35), 1999 (156 pp.).

-The examination of Blanco by White, concerning his Religious notions and other subjects connected with them begun on Sunday, Dec. 20, 1818. En Ángel G. Loureiro (ed.), «The examination of Blanco by White». Revista de Estudios Hispánicos, 33 (1999), 3-40 (texto en 835).

En la entrada dedicada a Blanco de mi Catálogo se detallaban los sucesivos escritos del escritor exiliado en su singular ejercicio de autobiografía permanente, sin parangón en las letras hispanas. Un gran avance sobre los escritos menores lo ofrece el libro de Garnica, con una introducción en la que explica la gestación y repercusión en 1845 de The life of the Rev. Joseph Blanco White. El volumen traduce textos no recogidos en 1845; el más importante es la primera traducción castellana de la Examination of Blanco by White ${ }^{16}$, que coincide con la primera edición del original inglés por Ángel Loureiro (con introducción y notas). Hay otras cuatro piezas: «Carta sobre la Inquisición», t. III de El Español (1811), que en realidad apenas puede considerarse un texto autobiográfico; «Despedida del autor de las Variedades a los hispanoamericanos», de octubre de 1825; la carta primera de su Practical and internal evidence against Catholicism (1825); y el texto equivalente, en forma de diálogo, de la versión popular del anterior libro, The poor man's preservative against Popery (1825).

Cada uno tiene una presentación y todos están anotados ${ }^{17}$.

\section{BORRELL VIDAL, JOSÉ ${ }^{18}$}

—Sesenta años de música (1876-1936). Impresiones y comentarios de un viejo aficionado. Madrid: Editorial Dossat, s. a. [1945] (267 pp.). Prólogos de Conrado del Campo y José María de Soroa.

\footnotetext{
${ }^{16}$ Un fragmento de esta traducción se había publicado ya: Sevilla en la mirada del recuerdo (textos de José Blanco White), Antonio Garnica y Jesús Díaz García (eds.). Sevilla: Ayuntamiento de Sevilla («Biblioteca de temas sevillanos», 47), 1994 (191 pp.).

${ }^{17}$ Véase mi reseña en Cuadernos de Ilustración y Romanticismo, 8 (2000), 199-204.

${ }^{18}$ No he hallado datos biográficos de este melómano, pero según cuenta, tuvo que nacer hacia 1870 en Madrid, ya que dice haber asistido en 1876 a sus primeras óperas, con sólo seis o siete años.
} 
El libro está dedicado a la memoria de Félix Arteta, creador de la Sociedad Filarmónica, a la que Borrell estuvo ligado y en parte supone una queja de la decadencia musical de Madrid en comparación con las décadas anteriores. Tras un «Preludio» del autor (19-20) donde reclama la busca de la sencillez y la sinceridad y pide disculpas por el desorden de su obra, siguen catorce capítulos con una disposición a medias cronológica, a medias temática, a menudo puramente asociativa, en los que evoca sus experiencias personales desde niño como aficionado a la música. Reúne gran cantidad de noticias, a veces acumuladas sin más, pero casi siempre acompañadas de sus impresiones y juicios, sobre obras, autores, representaciones, orquestas, intérpretes... Empieza con «Los comienzos de mi afición», las primeras óperas a las que le llevaron sus padres. Siguen «Mi juventud musical», «Bayreuth», «Los últimos diez años del siglo XIX», «La Sociedad Filarmónica», «La Orquesta Sinfónica», «Los últimos veinte años del Teatro Real», «La Sociedad Wagneriana», «La Orquesta Filarmónica», «Impresiones sobre algunos músicos», «Soliloquios sobre diversos temas», «Las Orquestas extranjeras en Madrid», «Nuestra zarzuela y el género chico», «Virutas». En el prólogo se atribuye a Borrell la siguiente exacta descripción de su obra: «un extenso escrito, a modo de Memorias, en que recojo impresiones, recuerdos, anécdotas y juicios personales sobre lo mucho que, en los distintos aspectos de la música dramática y sinfónica he escuchado durante tantos años de asiduo concurrente a teatros líricos y salas de concierto» (8). Se trata, pues, de unas memorias sectoriales, al estilo de los recuerdos profesionales o locales que proliferan en los últimos decenios del XIX y primeros del XX, y como todos éstos, de interés bastante limitado.

\section{7. [*90]. CALDERÓN ESPADERO, JUAN}

(Villafranca de los Caballeros, Ciudad Real, 1791 - Londres 1854. Franciscano que se significó como liberal y emigró a Francia en 1823, donde se hizo protestante y propagandista de su nueva fe en Inglaterra y España. Escribió periódicos, obras filológicas, espirituales y de exégesis bíblica.)

—Don Juan Calderón. [Autobiografía]. s. l. [Madrid]: s. i., 1855 (63pp. $)^{19}$.

${ }^{19}$ Las doce primeras páginas van en numeración romana, correspondientes a las dos primeras secciones de las cuatro que hay (la autobiografía es la tercera). Hay un raro ejemplar de esta edición en el fondo Usoz, encuadernado con otra obra de Calderón, el Cervantes vindicado de 1854 (BN, u-8804). En 
—Don Juan Calderón. Sa vie écrite par lui-míme, suivi de courtes notices sur quatre chrétiens espagnols et sur l'évangelisation de l'Espagne. París: J. Bonhoure et Cie., éditeurs, 1880 (71 pp.). Traducción francesa de Joseph Nogaret ${ }^{20}$.

—De las tinieblas a la luz. Autobiografía. Barcelona: Imprenta y Litografía de J. Robreño Zanné, $1884^{21}$.

-Autobiografía, Ángel Romera Valero (edición crítica y estudio). Ciudad Real: Ayuntamiento de Alcázar de San Juan, Patronato Municipal de Cultura — Diputación Provincial de Ciudad Real, 1997 (300 pp.). Texto de Calderón en 199-276²2.

En 1828, por encargo de Pyt, pastor protestante de Bayona que le convirtió al evangelismo, Calderón escribió una Nota sobre los acontecimientos de mi vida, relativos a mi conversión a la pura religión del Evangelio. Tras la muerte de Pyt en 1848, recuperó el manuscrito y a instancias del cuáquero inglés Benjamin Barron Wiffen escribió una nueva versión ampliada del relato. Es la que editó Usoz y se fecha en Londres, 18-VI-1849. Wiffen quería más datos concretos, y que siguiese la narración hasta ese momento (la parte nueva ocupa sólo unas diez páginas de la edición de 1997 y es meramente informativa), para darle uso dentro de sus proyectos de historia y estudio de los protestantes españoles, compartidos con Usoz. El texto de Calderón aún resultaba incompleto para esto, por no tener suficiente contenido biográfico y fuerza polémica, por lo que el editor lo rodeó en 1855 de otros elementos hasta completar cuatro secciones: un artículo biográfico hostil publicado en el periódico católico La Esperanza, extractos de cartas cruzadas por Calderón, Usoz y Wiffen, una bibliografía preparada

la portada de esta edición, que fue preparada por Usoz, sólo figura el nombre de Calderón, mientras que el término autobiografía se incluye en la página final al enumerar las obras del autor.

${ }^{20}$ Ejemplar en BN de París (Oo. 891). No es una mera traducción, sino una profunda reescritura del texto, que puede seguirse a través de la edición crítica de Romera, quien anota las modificaciones. Nogaret omite los textos de Usoz, dejando sólo el relato autobiográfico, pero ya en su prefacio (Bayona, 24-V-1880) dice que lo va a resumir y que añadirá «quelques épisodes communiqués par sa femme, et dont son fils [...] a autorisé la publication» (8). En efecto, incorpora numerosos pasajes narrativos, procedentes de transmisión oral familiar, al tiempo que poda buena parte de los excursos hímnicos propios del género espiritual y suaviza muchas de las ideas religiosas. El resultado final es un relato más lineal y narrativo.

${ }^{21}$ Esta rarísima reedición sigue el texto de 1855 y, según Romera, quien sigue a Fernández Campos (1991), hay un ejemplar en los sótanos del Instituto de Bachillerato «El Porvenir» de Madrid. Ángel Romera, por otra parte, también recoge una temprana noticia editorial en M. Alamo («Juan Calderón». Dictionnaire d'histoire et de géographie ecclésiastiques. París: Librairie Letouzey et Ané, 1949, XI, cols. 365-366): «según él, la Autobiografía fue editada en Londres en 1847 y 1850, pero no la he encontrado en los catálogos, y es probable que sea una de las numerosas erratas que contiene el artículo» (1997: 163164).

${ }^{22}$ La mayor parte de los datos contenidos en esta ficha proceden de la excelente y documentada edición de Romera, que debiera servir para poner de nuevo en circulación en las letras españolas a Juan Calderón. Incluye un extenso estudio biográfico y una completa bibliografía crítica y comentada, tanto primaria como secundaria. 
por Usoz... En esas misivas se ve cómo Wiffen y Usoz quisieron ampliar el material con más datos. El desencadenante de la edición fue, sin embargo, el tendencioso texto de $L a$ Esperanza (2-VII-1850), ante el que Usoz pretendía defender a su correligionario en un contexto de polémica entre católicos y protestantes.

Es un ejemplo modélico de autobiografía espiritual protestante: gira en torno a la conversión, estableciendo un itinerario del pecado a la redención, entendiendo por pecado el error religioso (el papismo) y el descreimiento (el ateísmo al que el papismo conduce), mientras que la redención viene a través de la Gracia. El relato tiene un fin edificante, ilustrar a los cristianos del poder redentor y la bondad de Cristo, y la posición del narrador es la de un pecador agradecido a la Providencia, que proporciona el orden narrativo a la biografía. El análisis de la evolución de su conciencia absorbe todo el interés, dejando en penumbras los acontecimientos y datos concretos, sólo apuntados en sus líneas generales. Lo que más desarrolla es su periplo desde la juventud hasta su crisis de 1824, que concluye con su conversión. El relato tiene, así, una firme y sostenida lógica interna, proporcionada por un finísimo y muy racional estudio de sus ideas espirituales y filosóficas, con admirable ritmo y progresión. Todo se adereza con frecuentes pasajes hímnicos y de acción de gracias, también en la tradición del género.

Bibliogr.: Marcelino MENÉNDEZ PELAYO. Historia de los heterodoxos españoles, libro VIII, cap. II, sección III / Gabino FERNÁNDEZ CAMPOS. «En el segundo centenario de Juan Calderón, filólogo, cervantista, traductor y periodista manchego». Palabra viva, 20 (nov.-dic. 1991) / Juan Bautista Vilar Ramírez. Intolerancia y libertad en la España contemporánea. Los orígenes del protestantismo español actual. Madrid: Ediciones Istmo, 1994 / Juan Bautista VILAR RAMÍREZ. «El filólogo, helenista y reformador religioso Juan Calderón, en la emigración liberal española de 1823-1833». En Antiguo Régimen y liberalismo. Homenaje a Miguel Artola. 3. Política y cultura, Pablo Fernández Albadalejo y Margarita Ortega López (eds.). Madrid: Ediciones de la Universidad Autónoma de Madrid - Alianza Editorial, 1995, 619-626.

\section{CALLE, PAULINO DE LA}

Véase: LACALLE, PAULINO DE 


\section{CALVO MURILLO, MATÍAS}

(Leciñena, Zaragoza, 1792 - entre 1852/1868. En 1808 estudiaba en la Universidad de Zaragoza. Combatió en el primer sitio de Zaragoza y en otras acciones en Aragón hasta 1809, en que huyó al monte. En 1811 se sumó a las guerrillas de Mina. No secundó el pronunciamiento liberal de su general en 1814, pero tuvo que dejar el ejército. El resto de su vida fue maestro y empleado municipal en Leciñena.)

—Noticias, y todo cuanto ha ocurrido durante la vida de Matías Calvo, que nació en 24 de febrero del año 1792, es decir, de aquellas cosas más nobles que han venido a la imaginación al estamparlo en este libro, para que así sus hijos, como demás que les sucedan a éstos lo tengan por si para alguna cosa les pudiera convenir. En Juan José Marcén Letosa. El manuscrito de Matías Calvo. Memorias de un monegrino durante la Guerra de la Independencia. Zaragoza: Mira Editores, 2000 (209 pp.), 174-209.

Matías Calvo escribió en su vejez este manuscrito de 18 páginas, contando los episodios cruciales de su vida. Su moderno editor lo considera inconcluso y sitúa su composición hacia 1852, aunque el testimonio textual sólo permite asegurar que es posterior a 1840. Escrito en Leciñena y sin divisiones internas, abarca 1792-1816. El autor había dejado fechas en blanco para completar, pero el final tiene solemnidad de cierre y sobreviene al concluir la etapa memorable de su vida, la de la guerra, de forma que es posible que sí esté terminado. El original permanece en poder de los descendientes de Calvo, y había sido empleado ya en trabajos de historia local. El libro de Juan José Marcén incluye: una introducción sobre el autor y su entorno geográfico e histórico (19-33); un minucioso comentario de las memorias (35-150), casi siempre orientado hacia prolijas aclaraciones de historia local y a lo largo del cual se reproduce el texto por trozos, en una versión alterada, o «adaptación libre» (37), para hacerla más fluida y actual; unos anexos con documentación adicional (151-163); una reproducción fotográfica y transcripción literal línea a línea del autógrafo en páginas confrontadas $(165-209)^{23}$.

Calvo escribe para sus herederos un relato sintético, ceñido a su aventura personal, que gira en torno a hechos de la guerra en Aragón, basándose en las impresiones dejadas en su memoria, sólo completadas con algunos datos fruto de la documentación

\footnotetext{
${ }^{23}$ Véase mi reseña de esta edición en Cuadernos de Ilustración y Romanticismo, 9 (2001), 201-202.
} 
posterior. El relato familiar y de infancia es brevísimo, ya que prefiere centrarse en sus años de combatiente, en concreto en las acciones ocurridas en el entorno de Leciñena. Muy consciente de su propia personalidad y de los cambios introducidos en ella por los avatares de su época, el relato deja sospechar una base oral de continua repetición durante años. El estilo es algo apresurado y a menudo incorrecto, lleno de fórmulas coloquiales, pero no exento de fuerza y viveza en sus momentos culminantes. Calvo gusta del detalle patético de los desastres y peligros de la guerra, aunque siempre está refrenado por el extremo deseo de concisión. Todo esto se relaciona con rasgos habituales de la autobiografía "popular», en la órbita de los ego-documentos: la escritura para el entorno familiar y local, el estilo llano y casi oral, la limitación de los hechos relatados y la humilde ausencia de pretensiones.

Bibliogr.: Juan José MARCÉN LETOSA. «El manuscrito de Matías Calvo: una visión particular de la Guerra de la Independencia». En La Guerra de la Independencia. Estudios, José Antonio Armillas Vicente (coord.). Zaragoza - Madrid: Institución Fernando el Católico - Ministerio de Educación, Cultura y Deporte, 2002, t. II.

\section{CAMPILLO DE ESTEBAN, FERMÍN}

(Activo en el servicio público entre 1795-1840, aproximadamente. Liberal exaltado, combatió en la Guerra de la Independencia y fue secretario de la Sociedad Patriótica de Murcia desde 1820, así como capitán de la milicia nacional. En 1823 fue represaliado sin poder obtener su rehabilitación luego.)

—Exposición de D. Fermín Campillo de Esteban, infanzón, condecorado con la cruz de las primitivas juntas superiores provinciales, y con las del segundo y tercer ejércitos en la Guerra de la Independencia, capitán de granaderos del primer batallón de la guardia nacional de Murcia, administrador general cesante de salitres y pólvoras, y (en calidad de por ahora) oficial primero de rentas de la misma provincia, juez de hecho y secretario por S. M. de la junta de enajenación de edificios y efectos de los conventos suprimidos. Murcia: Imprenta de D. Sebastián Hernández, 1835.

—Reimpreso en Barcelona: Viuda e Hijos de D. Antonio Brusi, 1840 (27 pp.) ${ }^{24}$.

\footnotetext{
${ }^{24}$ De la primera edición no quedan noticias, salvo las contenidas en la portada de la segunda, que es la que copio del ejemplar que se encuentra en BN, VC 2699/36.
} 
Ésta es una curiosísima muestra de manifiesto autojustificativo en verso. El manifiesto en sí, encabezado por el epígrafe «Señora» (la reina), ocupa la pieza $\mathrm{n}^{\circ} 1$ del opúsculo (3-17), y está en endecasílabos blancos, que comienzan: «En más de nueve lustros de carrera, / de distinguidos hechos y servicios, / ya en la sangrienta lid con el acero, / ya con la pluma en casos repetidos, / ya mejorando ramos importantes / que el gobierno a mi cargo poner quiso / de salitres, de pólvoras y azufres, / columnas de un estado regitivo; / nunca pensé, Señora, en otra cosa / más que en ser útil al Estado mismo, / descuidando mi suerte...» (3). Declara sus sacrificios por la causa nacional desde 1808, atribuyéndose méritos sin recompensa; luego desarrolla su carrera durante el Trienio en que ocupó cargos provinciales, siempre rodeado de oscuras malquerencias. En la p. 6 relata un motín antiliberal ocurrido en Alcázar de San Juan en 1823, en el que fue malherido, motivo inmediato de su quebranto, para luego seguir con las persecuciones subsiguientes y con la desatención de sus derechos tras la muerte de Fernando VII, que es lo que motiva la escritura. No falta la usual remisión a documentos: «Pues todo es evidente, todo consta / en documentos justificativos / presentados por mi mano propia / (para su curso a vuestros pies invictos) / al Director de rentas provinciales / el mes de marzo de este año mismo: / cuyo expediente en la sección se halla / del negociado general, unido / a la solicitud en que imploraba / salir ya del estado depresivo / a que un tiempo fatal me redujera» (15). Es verso prosaico, pero verso, que sólo modifica la estructura de un manifiesto justificativo en lo que impone la concisión poética y las exigencias y libertades de la métrica. Concluye pidiendo que se dé curso favorable a su expediente. Firma en Murcia, 17-XII-1835. Luego vienen, al menos en esta reedición otras piezas que continúan con su peripecia de suplicante, gestiones nuevamente realizadas en 1836, 1837 y 1839, recordando otra vez, ya en prosa, sus servicios y sus derechos.

Bibliogr.: Ángel ROMERA VALERO. «El trienio constitucional en Alcázar de San Juan. Una descripción inédita de un motín absolutista desconocido el 2 de mayo de 1823». Estudios sobre literatura e historia. Ciudad Real; 1993, 93-103 / Juan Calderón. Autobiografía, Ángel Romera Valero (ed.). Ciudad Real: Ayuntamiento de Alcázar de San Juan, Patronato Municipal de Cultura - Diputación Provincial de Ciudad Real, 1997, 70-74, 232, etc. 


\section{CAMPO VERDE, MARQUÉS DE}

Véase: GONZÁLEZ TORRES DE NAVARRA, LUIS

\section{0. [*96]. CAPMANY SURÍS Y DE MONTPALAU, ANTONIO DE}

—Relación sucinta... En Françoise Étienvre. Rhétorique et patrie dans l'Espagne des Lumiéres. L'oeuvre linguistique d'Antonio de Capmany (1742-1813). París: Honoré Champion ...éditeur, 2001 (510 pp.), apéndice I-A, 309-315.

En la monografía de Étienvre se incluye la primera edición moderna de la breve autobiografía literaria de Antonio de Capmany, a partir del texto íntegro de la primera edición, según el ejemplar de la British Library (1602/8), sin incluir el catálogo de los escritos del catalán que en ocasiones ha acompañado las ediciones anteriores. Se añaden notas al texto, principalmente léxicas y bio-bibliográficas, y le antecede un breve comentario con información básica ${ }^{25}$.

\section{CAVERO Y ÁLVAREZ DE TOLEDO, FRANCISCO}

(Zaragoza 1838-1905. General carlista. Tuvo destacado papel en la incursión montemolinista de San Carlos de la Rápita en 1860, como ayudante del general Ortega. Fue condenado a muerte, pero se le indultó. Tomó parte en la tercera guerra carlista. Vuelto a Zaragoza tras el exilio en Francia, fundó el diario El Intransigente).

- Copia literal de la narración de lo ocurrido en San Carlos de la Rápita, escrita por el Excelentísimo Señor Don Francisco Cavero y Álvarez de Toledo, teniente general de los Ejércitos de Carlos VII, cuyo original de puño y letra del indicado, conserva en su poder su nieto Don Francisco Cavero y Sorogoyen. En Jaime del Burgo. Fuentes para la historia de España. Bibliografía del siglo XIX. Guerras carlistas, luchas políticas. Segunda edición revisada y puesta al día con las publicaciones que han visto la luz hasta el año 1975 inclusive. Pamplona, 1978 (XXXII + 1072 pp.), 202b-204a.

${ }^{25}$ Con posterioridad al Catálogo de 1997 ofrecí una actualización de los datos sobre la Relación sucinta y un amplio estudio del texto dentro de mi tesis doctoral, leída en junio de 2001: La autobiografía moderna en España: nacimiento y evolución (siglo XVIII y principios del XIX). 
Se reproduce íntegro el documento, cuyo único epígrafe es un escueto Apuntes verídicos. Cavero escribe con familiaridad, dirigiéndose a un amigo que no identifica; se ciñe brevemente a lo que él vio o hizo. Hay una reflexión inicial sobre la solicitud de su amigo de «fechas y detalles de los acontecimientos de San Carlos de la Rápita»; no le parece fácil ni pudoroso el encargo, pero no quiere que queden en el olvido hechos que casi sólo él conoce y que abonan la grandeza de la Causa carlista. «Hecho este exordio de justificación a la petulancia que tal vez alguno pueda encontrar en mi narración, empiezo como los novelistas. Hallábame en Alcalá de Henares, siendo Alférez...» El relato comienza cuando Cavero es reclamado por Ortega para tomar parte en la conspiración de 1860 y termina con el fusilamiento de ese general. La mayor parte de la crónica alude a los preparativos del desembarco en La Rápita, después de él la historia se cierra con precipitación. El dato de mayor interés, los nombres de los grandes personajes que estaban comprometidos en el complot y que lo traicionaron, se lo reserva sin más explicaciones, aunque Del Burgo informa que Ortega, estando en capilla antes de su fusilamiento, le hizo jurar que jamás diría esos nombres. Se despide así: «Ahora que he escrito estos apuntes, comprenderás lo difícil que era para mí el darlos. Todavía recuerdo muchos detalles que harían más novelesca la historia, pero no digo más por hoy».

\section{CHAPÍ LORENTE, RUPERTO}

(Villena, Alicante, 1851 - Madrid 1909. Compositor musical, de éxito sobre todo en la zarzuela. Hijo de un barbero, en 1867 va a Madrid a estudiar en el Conservatorio; pasa penurias hasta que gana una pensión en la Academia de Bellas Artes de Roma desde 1874, que le permitió también vivir en Milán y París y estrenar numerosas obras que cimentaron su fama. En sus últimos años destacó como defensor de los derechos de autor.)

-Apuntes sobre mis primeros veinticinco años. En Memorias y escritos, Luis G. Iberni (ed.). Madrid: ICCMU («Música hispana. Textos. Serie A», 6), 1995 (167 pp.), 33-101. Prólogos de Salvador Mullos Menor y Alfredo Rojas; abundantes ilustraciones ${ }^{26}$.

${ }^{26}$ El resto del volumen son artículos publicados en prensa por Chapí sobre música. Sólo esa parte citada tiene interés como escrito autobiográfico. 
Estos Apuntes de juventud se escribieron en 1876 en Milán y debieron realizarse a instancias del crítico Peña y Goñi, comisario de los pensionados de música por la Academia de San Fernando, a quien se dirige en algún pasaje. El manuscrito ha sido facilitado a los editores por la bisnieta de Chapí, pero apenas se dan datos sobre él. Es una autobiografía completa del periodo señalado, hasta el momento de la escritura. Principia: «Yo no sé cómo y cuándo empezó en mi familia la afición a la música, pero ya mis abuelos la venían heredando y la transmitían a sus hijos» (35); y sigue un completo relato genealógico y semblanza de su padre... La vocación musical es el eje de la rememoración, aunque también evoca de modo extenso e íntimo su vida personal, su niñez y penalidades. Una vez superados sus primeros años de infancia, sólo se refiere a su carrera de músico: cómo componía, sus gustos, su aprendizaje, las obras que fue conociendo, las que fue haciendo, los detalles que definen la vida de un artista. Está redactado con gran sencillez, sin apenas énfasis, que sigue el orden cronológico y se hace más demorado según avanza en el tiempo. Al alcanzar sus veinticinco años, el relato se detiene y hace el autor una recapitulación del estado y el curso de su vida, con las incertidumbres y miedos propios de quien aún no ha asentado su vida laboral. Es obra valiosa por su tono personal e introspectivo.

\section{CIURANA BERENGUER, NARCISO ${ }^{27}$}

(Franciac, Gerona, 1871 - Maçanet de la Selva, Gerona, 1924. Masovero e hijo de masoveros, vivió con sus padres en masías de varias localidades catalanas, hasta que en 1896 se instaló por su cuenta en Maçanet. Estaba en camino de convertirse en propietario de la finca que cultivaba cuando murió.)

—Tribulacions d'un masover fadristern. Narcís Ciurana, de MaÁanet de la Selva, i el seu llibre de comptes i memòries, 1886-1912, Narcís Figueras y Joaquim M. Puigvert (eds.). Santa Coloma de Farners: Taller d’Història de Maçanet de la Selva - Centre d’Estudis Selvatans («Estudis i textos», 5), 1998 (112 pp.).

\footnotetext{
${ }^{27}$ Tanto en la edición de su obra como en el libro de Xavier Torres ya citado, se le nombra siempre como Narcís, pero él mismo, que escribe en castellano, se denomina Narciso en todo momento, así que me atengo a su propio uso.
} 
El manuscrito de Ciurana corresponde a un periodo muy temprano de su vida y consta de varios cuadernos escolares, algunos copiados con posterioridad, en posesión del Taller d'Història de Maçanet, aunque los editores no dan una descripción. El texto editado (61-112) conserva los rasgos esenciales de su pésima ortografía. El joven escribía en un castellano cuajado de rasgos catalanes, fruto de una escolarización muy precaria; muestra, con todo, que la sustitución lingüística, incluso en un ámbito íntimo y en una tradición centenaria en la sociedad catalana como la de los libros de familia, estaba sumamente avanzada. El volumen incluye dos elementos típicos del género: un libro de cuentas donde anota los gastos que hace su padre en vestirlo entre 1886-1896, mientras vivió bajo su autoridad; y un libro de memorias en que apunta de modo asistemático toda suerte de sucesos personales, familiares, climatológicos..., entre 18861912. De hecho, sólo las primeras páginas pueden considerarse una autobiografía, que empieza: «Esplicación de la vida de un niño hobediente y de toda la bondad. / Capítulo primero. / Yo mismo escribió estas letras empiezando a escribirlas en la edad de 15 años, cumpliéndolos al día 26 de Abril de 1886» (63). Hasta la p. 67 recapitula su corta vida, que es la parte que me interesa. Señala su nacimiento «en este desgraciado mundo; así Dios me hubiese quitado la vida antes de llegar» (63), quejándose de sus muchas aflicciones y trabajos. Se ocupa de cuando sus padres lo envían a la escuela, de los cambios de residencia y trabajo de la familia, todo en un tono quejumbroso y obsesionado por el dinero, en un estilo pobre, infantil y repetitivo. El asunto que más desarrolla es su elección de oficio frustrada por las imposiciones de su padre, así como los problemas entre los hermanos a causa del servicio militar. Por lo demás, el contenido es disperso y poco productivo. A partir del capítulo segundo (68) empieza a anotar los gastos y ocurrencias principales desde 1886 en adelante, y la obra se transforma en un libro de sucesos familiares. El rasgo psicológico que más destaca es su resentimiento hacia su padre y su hermano mayor, el hereu: se siente explotado por una familia cicatera, lo que da a su escrito un sentido pesimista y resignado de tintes religiosos.

\section{COLL Y PRAT, NARCISO}

(Cornellá de Ter, Gerona, 1754 - Madrid 1822. En 1808 fue designado arzobispo de Caracas, adonde llegó en 1810 en medio de la revolución. Padeció seis años de 
sangrientas guerras y cambios políticos. Era un realista moderado, que contemporizó con las autoridades independentistas y fue acusado ante el gobierno: en 1816 regresó a España a rendir cuentas. Fue rehabilitado en 1821 y nombrado obispo de Palencia poco antes de morir.)

—Memoriales sobre la independencia de Venezuela, Manuel Pérez Vila (ed.). Caracas: Biblioteca de la Academia Nacional de la Historia, Sesquicentenario de la Independencia, 1960 (405 pp.).

La actuación de Coll en Caracas, por su moderación política y piedad humana ante la guerra, le hizo sospechoso a ambos bandos. Escribió varias justificaciones, de las cuales tres se recogen en el libro de 1960. 1. Memoria a la Regencia de 1812 (43-81), escrita en 25-VIII-1812, tras el triunfo de Monteverde, que abre un periodo de dominio realista en Venezuela ${ }^{28}$. Expone «la conducta pública y privada con que me he conducido desde el día 24 de mayo de 1810, en que salí del Puerto de Cádiz para este Arzobispado hasta el día presente». La forma es puramente narrativa y con bastante pormenor, a modo de memorias testimoniales. La estrategia de autodefensa forma parte de ese plan narrativo, en el que protesta su odio a los sublevados y a «todas las ideas infernales subterráneas, antirreligiosas, antisociales y anti-hispanas» (54). Explica los vaivenes de la crisis, particularizando siempre su conducta de cada momento, sin atender a ningún otro tema personal, y a lo pastoral sólo en la medida en que se relaciona con lo político. 2. Exposición al gobierno de 1818 (83-386). Es la obra magna de Coll, que tenía pretensión de publicarla. Fechada en Sevilla a 23-VI-1818, recoge y amplía la relación de 1812 y otra hoy desconocida de 1814. Así pues, toda la obra de Coll es una reelaboración en distintos formatos y fechas de la misma materia, de la que esta pieza es la versión más desarrollada ${ }^{29}$. Se divide en siete secciones cronológicas

${ }^{28}$ El manuscrito original en el Archivo de Indias, Real Audiencia de Caracas, leg. 953. Ya había sido publicado antes por Héctor García Chuecos, Historia documental de Venezuela, Caracas, 1957, 228253.

${ }^{29}$ El título completo es Exposición que al Rey Nuestro Señor en su Real y Supremo Consejo de las Indias, hace el Arzobispo de Caracas, adelantando sus cartas de 25 de agosto de 1812 y 5 de julio de 1814, dirigida por el Ministerio de Gracia y Justicia, sobre lo que le ha ocurrido en el Gobierno de su Diócesis desde 15 de julio de 1810 en que llegó al puerto de La Guaira, hasta 8 de diciembre de 1816 en que, cumpliendo la Real Orden de 14 de marzo del mismo, se embarcó en el propio puerto para esta Península. 1818. Comprendía un volumen de 176 hs. en folio, con tomos de documentos adjuntos; el original estuvo en el Consejo de Indias y luego en el ministerio de Gobernación de Ultramar. Pérez Vila no tiene noticias de su paradero, sino que edita una copia contemporánea, propiedad de un historiador venezolano: IV + 182 ff. numerados, $21 \smile 30$ cm., encuadernado, escrito de la mano del secretario de Coll, Tomás Quintero, que copia las notas documentales de la exposición sólo hasta la mitad del texto; no incluye los documentos anexos. 
según los sucesos venezolanos. Este cuerpo central supone unas completas memorias justificativas. Es el mismo relato de 1812, aunque continuado hasta 1814, más desarrollado y trabajado, con un estilo más literario y hartos más detalles que la otra vez. Al terminar el hilo narrativo, hay una sección cuyos epígrafes «hacen la enarración del origen, fundamentos, progresos, y estado actual de la actuación económica e instructiva que motiva esta memoria expositiva, examinan aquéllos, analizan en la parte correspondiente los Documentos que a la actuación se han agregado, y anulan cargos determinados» (88). Es la argumentación doctrinal y jurídica de su defensa frente a los cargos recibidos, compleja y densa, con cita de autoridades teológicas, canónicas... Termina con una representación dirigida al Rey implorando se le haga justicia. 3. Informe al Papa de 1822 (387-403). Es un documento subsidiario del de 1818, respuesta en tercera persona a un cuestionario del nuncio sobre el estado de su diócesis $^{30}$. Lamenta no haber podido imprimir la exposición de 1818, como hubiera sido su deseo, así pues resume «lo más principal y perentorio de que habló entonces, no pudiendo añadir cosa alguna con posterioridad» (390). A partir de ahí repite muy resumidamente la misma historia que ya había escrito.

\section{CORIS, ANTONIO}

(Religioso oratoriano, tomó parte muy activa en la resistencia de 1808 contra los franceses y en las luchas habidas en Cataluña hasta mediados de 1811 entre el autoritario jefe militar marqués de Campo Verde, del que era partidario, y los individuos de la Junta regional, el canónigo Avellá entre ellos.)

-Manifiesto que ofrece al juicio del público el P. Antonio Coris, presbítero del Oratorio de San Felipe Neri, de su conducta durante la guerra actual, y el mismo que podrá servir de contestación al escrito publicado por el Canónigo D. Pedro José Avellá y Navarro, supuesto Juez comisario del Breve Apostólico en Cataluña. Palma: Imprenta de Antonio Brusi, 1811 (46 pp.).

Coris fue encarcelado por sus enemigos bajo el cargo de conspiración; Campo Verde, a su vez, había destituido y encarcelado a Avellá y a otros de su grupo. Hubo un cruce de folletos entre Campo Verde (véase su entrada en este mismo trabajo) y el

${ }^{30}$ Lo había editado el jesuita Pedro Leturia, La emancipación hispanoamericana en los informes episcopales a Pío VII, Buenos Aires, 1935, 68-82. 
general Sarsfield, y otro, el que ahora interesa, entre Avellá y Coris ${ }^{31}$. La defensa de Coris consta de un texto sin subdivisión alguna, que se inicia con una breve presentación indignada (3-4). «El vulgo preocupado con un falso principio cae fácilmente en la tendida red, y el hombre de honor después de repetidos e incesantes servicios se ve abatido, despreciado, y aun ultrajado por aquellos mismos, cuya felicidad le ha costado infinitos desvelos. ...sta es, a corta diferencia mi historia desde que nuestros enemigos invadieron la provincia, hasta la época actual» (3). Pese a sus sacrificios patrióticos, se ha visto calumniado como «jefe de revolución, hombre sanguinario, capitán de descamisados y otros injustos dicterios» (4) y como algunos han creído los cargos, ha de publicar la defensa de su honor. A continuación comienza el relato: «Apenas vi en el aciago día 13 de Febrero de 1808, que nuestros opresores invadían con mentidos pretextos la capital del principado, ya no me quedó duda en el injusto fin a que se dirigían...» (4). Se lamenta de la indolencia de las autoridades, mientras que él asumió la necesidad de movilizarse contra los franceses: expone sus actividades conspiratorias, viajes bajo disfraz, planes militares, su papel en la defensa de Tarragona... En medio de esto, surgen conflictos político-militares intestinos, en los que Avellá fue preso; allí nació la rivalidad que explayan estos papeles. No obstante esta dimensión de apología, el autor prefiere mantenerse en un plano narrativo: «Como mi intento no es otro que el de manifestar mi conducta [...], omito entrar en el pormenor de las infundadas y odiosas calumnias con que [...] [Avellá] se cree autorizado para ultrajarme» (30). Tras esos pesares, se retiró a un segundo plano, pero sigue narrando otros episodios y termina con varias páginas de alegato final por su conducta y en contra de Avellá. Se firma en Arenys de Mar, a 20-XII-1811. Al final hay una «Advertencia» (44) en que explica por qué califica a su rival de «supuesto» juez del breve, en función de razones canónicas. Sigue una «Nota» con nuevas consideraciones por un escrito que acaba de ver, El mayor despotismo, de Ramón María Sala, cuñado de Avellá (45-46). En el texto cita con frecuencia los testigos que abonarán sus aserciones, y desarrolla en notas a pie de página los documentos que las atestiguan. En suma, un ejemplo más de memorias justificativas.

\footnotetext{
${ }^{31}$ Empezó Avellá con su Manifiesto que presenta al juicio y censura de la Nación Española D. Pedro José Avellá y Navarro, canónigo de la Santa Iglesia de Barcelona e individuo de la Junta Superior de Guerra. Palma de Mallorca: Oficina de Antonio Brusi, 1811 (40pp.). El folleto de Coris es réplica de éste pero a su vez Avellá continuó la batalla en otros dos opúsculos: Adición primera al manifiesto que presentó al juicio y censura de la Nación Española... Palma de Mallorca: Oficina de Antonio Brusi, 1812 (15 pp.); y Adición segunda al manifiesto que presentó al juicio y censura de la Nación Española... Palma de Mallorca: Oficina de Antonio Brusi, 1812 (24 pp.).
} 


\section{CUÑAT Y SERRA, MARIANA}

(N. en 1750. Casada a los diecisiete años, a los veintinueve se convirtió a la vida devota.)

—Relación de varios hechos de mi vida, Biblioteca General e Histórica de la Universidad de Valencia, ms. 762, 178 fols. escritos, redactado a principios del XIX según referencias internas.

Esta autobiografía espiritual se incluye dentro de un volumen que incorpora también coplas a la Virgen. Según la descripción de Marcelino Gutiérrez del Caño, son «216 hojas útiles, excepto la 1ª, 123 a 207 y tres últimas, a 33 líneas.—Papel 0,215 alto ` 0,144 ancho; caja de escritura 0,195`0,127. - Letras s. XVIII. / Protestación. — P. en 61. - Texto. Coplas que terminan: / Estas coplas de la Virgen / soñando se compusieron / y porque la Virgen ablava / mis manos las escribieron» ${ }^{32}$.

\section{7. [*127]. DELGADO, SINESIO ${ }^{33}$}

27.1.

-Mi teatro. En ABC (Madrid), 1, 19-VI, 4, 10, 17, 24, 31-VII, 6, 14, 21, 27-VIII, 4, 11, 18, 25-IX, 2, 9, 16-X, 2, 8, 14, 20, 27-XI, 4, 11, 18, 21, 26, 29-XII-1905.

—Mi teatro. Madrid: Imprenta de los hijos de M. G. Hernández, 1905 (279 pp.).

- Mi teatro. Madrid: Edición Homenaje de la Sociedad General de Autores de España en el Centenario del Nacimiento de Sinesio Delgado, 1960 (245 pp.). Trabajos sobre Delgado de Melchor Fernández Almagro, Alberto Delgado, Francisco Serrano Anguita; ilustraciones de Ramón Cilla.

- Mi teatro. Cómo nació la Sociedad de Autores. Reedición facsímil de la edición de 1905. Prólogo de Eduardo Bautista. Estudio biográfico de María Luz González Peña. Madrid: Sociedad General de Autores y Editores - Fundación Autor, 1999 (89 + 279 pp. + 5 hs.).

32 Marcelino Gutiérrez del Caño. Catálogo de los manuscritos existentes en la Biblioteca Universitaria de Valencia. Valencia: Antonio López y Cía., 1913 (3 vols.). Es el ms. 739 de esa catalogación. He tenido noticia de esta autobiografía por Mónica Bolufer Peruga, de la Universidad de Valencia; agradezco también a Beatriz Ferrús Antón, de la misma universidad, haberme hecho algunas consultas al respecto.

${ }^{33}$ En mi Catálogo de 1997 recogí las dos ediciones en libro de Mi teatro, de 1905 y 1960 . Ahora añado la primera publicación en prensa y una reciente reedición; actualizo, pues, la parte bibliográfica sin repetir el resto de la entrada. A continuación incorporo noticia completa de otra obra autobiográfica distinta. 
27.2.

—Fernando Delgado Cebrián. «Memorias de Sinesio Delgado». Villa de Madrid, 97-98 (1988), 60-73; 101 (1989), 45-63; 105-106 (1991), 103-119.

En esta revista madrileña se empezaron a publicar por un descendiente de Sinesio Delgado otras memorias manuscritas del escritor que no han visto la luz por entero, según mis noticias. Si Mi teatro se centraba en su trabajo dramático y en la fundación de la Sociedad de Autores, esta otra obra evoca el conjunto de su vida literaria. Delgado Cebrián: «El manuscrito de sus Memorias llevaba por título Cuarenta años en Madrid, luego tachó la primera parte y lo intituló Medio siglo en Madrid (Memorias de un escritor público de tercera fila). Le acompaña una cuartilla, doblada por la mitad, en la que se consignan los capítulos en los que pensaba dividir su obra. Van numerados del 1 al 91 y los antecede un prólogo sin numerar. A los 17 primeros precede un aspa que indica que da por definitivamente escrito el capítulo, lo mismo ocurre con los numerados con las cifras 19, 22, 24, 28, 32, 34, 36, 46, 49, 50, 57, 58, 66 y 72 . No hay más escritos, aunque yo he encontrado en un copiador de cartas, escrito a lápiz, el que sería el número 21, que he añadido, aunque él no lo diera por válido. Busqué entre sus papeles con la esperanza de encontrar alguno más, pero sin éxito» (62). Lo publicado abarca el prólogo, donde explica su nacimiento y dice que con sesenta años que tiene lo que puede hacer es morirse o «ponerse a escribir sus memorias íntimas, si en un rasgo de vanidad cree que pueden ser interesantes para las generaciones venideras» (63); y los diez primeros capítulos, que comienzan con su llegada a Madrid para colaborar en Madrid cómico y siguen con sus relaciones con otros escritores, como Ricardo de la Vega, Ramón Chíes, el semanario satírico La Viña, su trato con Alfonso XIII... Escribe en su habitual estilo ameno, lleno de diálogos, anécdotas y bromas, una narración plena de detalles y muy literariamente elaborada que constituyen unas auténticas memorias de escritor.

\section{ESTRADA Y CATOIRA, RAMÓN}

(La Habana 1852 - Madrid 1927. Marino y escritor. Mandó diversos buques de la Armada y llegó a vicealmirante en 1914; jefe de la comisión hidrográfica, director general de personal, consejero del Tribunal Supremo de Guerra y Marina. Era 
especialista en navegación, radiotelegrafía y cartografía náutica, sobre lo que escribió manuales.)

— «Recuerdos de tiempo viejo». Revista general de marina, 93 (octubre de 1923), 447-467. [Viaje de la fragata blindada Arapiles.]

— «Recuerdos de tiempo viejo». Revista general de marina, 94 (marzo de 1924), 309-344.

[Continuación del viaje en la fragata blindada Arapiles.]

— «Recuerdos de tiempo viejo». Revista general de marina, 95 (noviembre de 1924), 593-618. [La

Revolución del sesenta y ocho, la Gloriosa y la fragata de guerra Zaragoza.]

— «Recuerdos de tiempo viejo. Viaje del transporte «Legazpi» a los islotes de la Salud en busca del crucero «Filipinas”». Revista general de marina, 98 (mayo de 1926), 637-651.

— «Recuerdos de tiempo viejo. Los ciclones antillanos». Revista general de marina, 100 (febrero de 1927), 177-181.

— «En el crucero Extremadura. Recuerdos de tiempo viejo». Revista general de marina, 100 (junio de 1927), 849-855.

— «Recuerdos de tiempo viejo. El cincuentenario de la Revista». Revista general de marina, 101 (septiembre de 1927), 341-344 ${ }^{34}$.

Estrada publicó su primer artículo tras leer en el $A B C$ uno de los que formaban parte de las Memorias de un gacetillero de Francos Rodríguez, en el que se hacía alusión a Juan de Dios Rada Delgado: «Esto evocó en el que suscribe un recuerdo gratísimo de la primera juventud; de guardia marina, el año 1871, en que, formando parte de la dotación de la fragata Arapiles, recorrió los puertos del Mediterráneo oriental, llevando a bordo una comisión presidida por el Sr. de la Rada». Dedica varias páginas a narrar ese viaje, a comentar quiénes eran los tripulantes y quiénes los comisionados, glosando también el libro que dedicó Rada a tal evento. El eco de este primer artículo le animó a ir dando a luz otros varios, siempre en un tono ligero parecido, dedicados monográficamente a algún aspecto de su biografía naval, sin Espíritu sistemático. El segundo artículo cuenta un episodio de la rivalidad entre España y Estados Unidos por Cuba; en la tercera entrega explica su participación (involuntaria) en el alzamiento de la Armada en Cádiz en 1868 y, desde una visión muy conservadora, se hace una crítica de la Revolución; la cuarta desarrolla un episodio de rescate de un barco encallado en el Caribe, fracaso de la moderna construcción naval española; el

\footnotetext{
${ }^{34}$ De todos estos artículos hubo edición separada, siempre por la Imprenta del Ministerio de Marina, algunos de los cuales pueden consultarse en la BN. Varios llevan láminas y dibujos del contralmirante Felipe de Arnáiz.
} 
quinto artículo se ocupa de sus experiencias con los huracanes antillanos; el sexto es su mando del buque Extremadura y las misiones que en él realizó; el último, de encargo y más breve de lo habitual, son sus recuerdos de la Revista general de marina.

Son memorias dispersas y que huyen de la subjetividad. En la segunda entrega asegura procurar «que figure lo menos posible mi persona, [...] por no caer en el defecto de que generalmente adolecen las crónicas o memorias, defecto consistente en que la Historia parece girar en torno del narrador o enlazarse estrechamente con él. Sin embargo, a veces no será posible prescindir de referirme a lo que yo mismo vi, para aclarar o dar mayor realce al episodio [...]: perdónenme los lectores». Todo tiene un estilo blando, amable y elogioso —a veces rayano en la ñoñería-, falto de toda penetración o intensidad. A menudo afirma consultar apuntes, diarios u otra clase de documentación.

\section{FERINGÁN Y CORTÉS, SEBASTIÁN}

(Báguena, Teruel, 1700 - Cartagena, Murcia, 1762. Ingeniero militar. En 1717 pasó a Barcelona con un hermano militar, en 1718 ya es ingeniero en las obras del puerto; en 1726 participa en el sitio de Gibraltar y desde 1728 hasta su retiro en 1762 estuvo en Cartagena al cargo de las obras portuarias, de la construcción del Arsenal y otras muchas tareas.)

-Patria, edad, origen, estado, salud, empleos y en ellos servicios continuados [...] desde $1^{\circ} \mathrm{de}$ noviembre de 1718 hasta 19 de junio de 1754 del coronel D. Sebastián Feringán Cortés... En Pedro A. Berenguer y Ballester. Documentos y noticias para la biografía del general de ingenieros D. Sebastián Feringán y Cortés, reunidos por Pedro A. Berenguer y Ballester, capitán de infantería. Madrid: Imprenta del «Memorial de Ingenieros», 1896 (133 pp.), 7-35.

El original de este documento fue hallado en el Archivo de Simancas por Berenguer, quien sostiene «que puede reputarse cual verdadera autobiografía, tan ingenua, tan llena de curiosos pormenores acerca de su vida y trabajos, que, sin ser un escrito literario, se lee con suma complacencia y deja en el ánimo la grata impresión de la confidencia hecha sin reservas, por un hombre sencillo que siente su conciencia tranquila y se halla satisfecho de haber llenado dignamente su misión en todas ocasiones» (5-6). Esta visión es demasiado optimista, ya que no es sino una típica 
relación de servicios, si bien más desarrollada y personalizada de lo usual. Feringán atiende una real orden de 1754 reclamando noticia individual de los ingenieros militares. Los primeros y extensos párrafos reconstruyen la genealogía, calidades y honores de su familia. A partir de aquí sigue con sus estudios, que explica, sin limitarse a mencionarlos; expone sus motivaciones, las inclinaciones de su genio, etc., lo que le singulariza de una mera relación administrativa. Entra luego en el detalle de sus servicios como ingeniero: como considera que sería prolijo enumerarlos por lo menudo, se limita desde la p. 17 hasta el final a hacer «un resumen cronológico», dejando clara su cualificación profesional. Termina despidiéndose de la «sincera confesión que en estas catorce fojas dejo hecha. Cartagena 19 de junio de 1754» (35). Este opúsculo es muestra de la deriva autobiográfica a que conducen las relaciones de servicios, otro de los canales por los que se institucionaliza la reflexión sobre uno mismo.

Bibliogr.: José María de JAIME LORÉN y José de JAIME GÓMEZ. «Sebastián Feringán y Cortés (Báguena, 1700-1762). Arquitecto e ingeniero militar, constructor del Arsenal de Cartagena entre otras importantísimas obras». Xiloca. Revista del Centro de Estudios del Jiloca (Calamocha), 15 (diciembre 1995), 207-231.

\section{FERNÁNDEZ CAÑAS, JUAN}

(M. en Almuñécar, Granada, 1815. Era alcalde de Otívar durante la Guerra de la Independencia, y fue un durísimo guerrillero contra los franceses en las Alpujarras a partir de 1810. Se retiró a Almuñécar después de la guerra.)

-Relación de las acciones dadas a los franceses por mí, el coronel D. Juan Fernández (a) el alcalde de la villa de Otívar, desde el 25 de mayo de 1810 hasta hoy día de la fecha.

Este manuscrito de Fernández Cañas, probablemente dictado a un amigo, quedó en poder de sus descendientes. Lo mencionaron Alarcón en La Alpujarra y Lafuente Alcántara en Historia de Granada; luego Gómez de Arteche se hizo con una copia, al parecer fragmentaria; lo denomina «diario de operaciones» y es su principal fuente para reconstruir en resumen, paráfrasis y citas la peripecia del guerrillero. En 1893 Eduardo Ligero Fernández, dueño del documento, lo regaló a Natalio Rivas, a la sazón presidente de la diputación de Granada: eran dos cuadernos, uno con el relato y el otro con 
documentos autentificados. Rivas hizo gestiones para publicar el texto en 1897 ante Cánovas, a quien pidió un prólogo y le hizo cesión del primer cuaderno. Tras la muerte del político no pudo recuperar el manuscrito, aunque guardaba copia. Sólo en su discurso de 1940 pudo Rivas dar a conocer la obra; desde la p. 21 vacía su contenido, que comienza con la invasión del reino de Granada a principios de 1810: «Aquí principiaron a hervir en mi pecho los más amargos sentimientos y a conocer los efectos del verdadero patriotismo» (cita en Rivas, 25-26). Se reproducen largos fragmentos del relato, centrado en la vida militar del autor, con aire de justificación de servicios para obtener recompensa. Los pasajes muestran un estilo minucioso pero de poco vuelo, que cree impresionar con el registro de cifras y datos sin apenas elaborar. Oscila entre autobiografía popular y relación de servicios, más que memorias militares. A partir de la p. 34, Rivas copia cartas cruzadas entre el alcalde y los franceses, y añade algunos papeles del legajo de certificaciones.

Bibliogr.: José GÓMEZ DE ARTECHE. Nieblas de la historia patria. Segunda serie. El marqués de Torrecuso - Un proyecto estupendo - El alcalde de Otívar. Madrid: Imprenta a cargo de Víctor Saiz, 1876, 157-228 / José Gómez de Arteche. Nieblas de la historia patria. Segunda edición corregida, aumentada y con ilustraciones. Barcelona: Establecimiento tipográfico de Fidel Giró, 1888, 104-150 / Natalio Rivas Santiago. El alcalde de Otívar, héroe en la Guerra de la Independencia.

Discurso... en su recepción pública... el día 29 de junio de 1940. Madrid: Real Academia de la Historia, [1940] (73 pp.).

\section{FERNÁNDEZ IGLESIAS, ARTURO}

(Cáceres 1869 - d. de 1942. Armero, propietario de una famosa armería «Arturo», en la madrileña calle de Hortaleza, desde 1898. Sobresalió también como impulsor del tiro deportivo a través de clubes, asociaciones y concursos; fue coleccionista de arte y de armas antiguas.)

— «Arturo.» Recuerdos de mi vida. Madrid: Luis Cárcamo, editor, 1982 (819pp.). Con abundantes fotografías. 
Una nota del editor especifica que, por deseo de los familiares, promotores de la publicación, se ha respetado la integridad del texto y su estilo. Esta autobiografía se escribió «durante los años de la Guerra Civil en Diego de León35 —mientras bombardean Madrid y con mis hijos en el frente. El Epílogo en mi casa de Hortaleza entre Junio y Agosto de 1942, todo ello con ayuda de mi memoria y de Antonia, mis apuntes, archivo de Canto Blanco, libros de mi biblioteca, y los periódicos y revistas de la época» (818). Se abre con dos prologuillos a los lectores, en los que pide disculpas por su falta de arte literario y dice que su motivación es «reflejar sobre el papel mi vida con el sano propósito de que mis hijos y nietos conozcan y se empapen bien, de las luchas que en esta vida he sostenido» (5), aunque también piensa en un lector anónimo, a quien le pide que si no le gusta no lo lea, pero que no lo tire, porque es la obra de un trabajador manual. Otro móvil para escribir es ocupar el tiempo libre con esa diversión ahora que no puede trabajar, pues no soporta la ociosidad.

Una primera parte (9-93) se dedica a su nacimiento e infancia en Extremadura, familia, escuela, primeros recuerdos de cacerías, su vocación de armero, y sobre todo su crucial decisión de irse a Madrid en 1888. La segunda parte (95-801) cuenta sus impresiones de Madrid y sus esfuerzos por abrirse paso como armero, pero también sus visitas al teatro, mítines de Pi y Margall, amistades, cacerías a las que era asiduo y que le ponen en relación con intelectuales, aristócratas y políticos. Gran parte del texto se lo llevan las vicisitudes de su noviazgo. Desde que inicia su propio negocio (463 y ss.) la temática insiste más en lo profesional y en su participación en las primeras sociedades españolas de tiro deportivo... En cierto momento expresa sus dudas sobre si está siendo demasiado prolijo, con lo que decide «reseñar lo más saliente de mi vida con la mayor brevedad, y del medio ambiente en que he vivido. [...] Dejaré de escribir de mis seres más queridos, que sólo a los míos pudiera interesar, para no pasar por el trance doloroso del recuerdo del día que se fueron para siempre...» (528-529). A partir de aquí se ocupa también del coleccionismo, de sus competiciones deportivas...: en suma, de una temática más externa. Sus padecimientos en la guerra llenan la última sección propiamente autobiográfica (639-658): asaltos a su armería, detenciones, movilización de sus hijos, miedos y bombardeos. No muestra partidismo político, aunque sus ideas parecen cercanas a un republicanismo burgués nada revolucionario. Con eso termina el relato de su vida, pero el libro sigue: «para que esta narración sea más completa, ahora os voy a contar lo que sucedió en Madrid, en España y en el mundo, durante estos años» 
(658), dando paso a unas memorias retrospectivas de lo ocurrido entre 1900 y 1936, en epígrafes encabezados por series de años (658-801) y consagrados a la vida política, cultura, espectáculos (teatro, toros, cine) y deportes. Un melancólico «Epílogo» (803817) da cuenta de lo acaecido desde el final de la guerra hasta 1941, con amargura por el revanchismo de los vencedores.

El largo relato se divide en epígrafes de extensión desigual y temática variada. Prepondera un orden cronológico, aunque mediatizado por el desorden de una escritura que no parece haberse corregido ni planificado. Fernández se expresa en tono cercano y ternurista. Frase corta, párrafo corto y estilo coloquial, en diálogo con los lectores, aunque en ocasiones también pretende mostrar sus opiniones sobre el mundo de manera más elaborada y con lenguaje más culto. Abundan los diálogos y las anécdotas. Apenas hay vida íntima, pero sí mucha privada, rica en detalles, aunque tal acumulación de pequeñeces resulta excesiva. El sentimentalismo es superficial y tópico, sin honduras humanas ni cualidades de estilo que le rediman del exceso de familiaridad.

\section{FERNÁNDEZ DE LEÓN, ESTEBAN}

(Esparragosa de Lares, Badajoz, 1748 - Madrid, 1819. político y hacendista. Hacia 1763 se instaló en Venezuela, donde hizo carrera en la administración de rentas, culminada desde 1791 como intendente de Caracas. En 1802 regresó a España. En 1808 se sumó a la sublevación; fue nombrado en 1810 para la primera Regencia, aunque tuvo que dimitir a los tres días. Fue luego uno de los responsables de la orden de libre comercio de mayo de 1810, que le costó un proceso judicial.)

—Relación de los servicios y méritos de D. Esteban Fernández de León y de su conducta en la anterior revolución contra Napoleón y a quien se debió ésta. Publicada parcialmente en: Nicolás Pérez Jiménez. «Los extremeños de tierra de Serena en la guerra de la Independencia». Revista de Extremadura (Cáceres), tomo X (1908), no 105, 106, 107, 108 y 111, pp. 128-132, 155-163, 211218, 245-252 y 444-450.

Este documento, fechado el 31-VIII-1814 en Madrid, fue publicado en varias entregas sin describirlo y sin indicar su procedencia. No obstante, Juan Andreo ${ }^{35}$

\footnotetext{
35 Juan Andreo García. La intendencia de Venezuela: Don Esteban Fernández de León, intendente de Caracas, 1791-1803. Murcia: Universidad de Murcia, 1991, 15 y 73-80 passim.
} 
localizó el original en AHN, Estado, leg. 878, y explica que se trata de un escrito destinado a su justificación política ante Fernando VII, para que se le restituyesen sueldo y rango tras haberse suprimido los que concedieron los gobiernos liberales; Fernández de León pretendía probar sus méritos patrióticos y sus sacrificios de dinero, para lo cual en el legajo se acompañan estadillos financieros, listas de gastos para la guerra, etc. Andreo, fuera de esto, tampoco describe por extenso el manuscrito, con lo que es preciso aún manejar lo editado en Revista de Extremadura con pasión regionalista por Pérez Jiménez.

La primera entrega es una introducción general a la Guerra de la Independencia y a su incidencia extremeña. La segunda trata de Fernández de León, cuya figura desea el editor sacar del olvido. «De la Relación autobiográfica inédita [...] entresacamos los apuntamientos biográficos [...] y nuevos datos para la historia de la guerra» (158). A partir de aquí resume, extracta y discute el contenido. Por sus citas literales, resulta un completo relato de sus pasos en la guerra; no se equivoca Andreo en atribuirle una finalidad autoapologética, pero es algo más que una relación administrativa, pues está bastante circunstanciada y posee muchos elementos testimoniales. Uno de los primeros fragmentos extensos que reproduce Pérez Jiménez es donde el autobiógrafo se atribuye la iniciativa del bando del alcalde de Móstoles comunicando al reino lo ocurrido el 2 de mayo (Pérez Jiménez cree que este hecho desconocido fue uno de los motivos centrales del documento, al señalar en el título la revolución... y a quien se debió ésta). La tercera entrega se ocupa de sus operaciones para organizar las guerrillas en Extremadura durante 1808. Sigue habiendo largas citas literales que ofrecen un carácter inequívoco de memorias testimoniales, más aún que apologéticas. La cuarta entrega versa sobre su efímera Regencia, ataca a Miguel de Lardizábal y explica las razones verdaderas de ese conflicto (su apoyo al libre comercio americano). El quinto artículo concluye la biografía de Fernández de León hasta su muerte y defiende su propia versión del conflicto por la orden sobre comercio de Indias ${ }^{36}$.

\footnotetext{
${ }^{36}$ Andreo también da esta noticia: en 1813-1824 «...Don Esteban va a terminar sus «Memorias», que según el profesor Briceño [Mario Briceño Iragorri. Casa León y su tiempo (aventuras de un anti-héroe). Caracas: 1947, 195], venía escribiendo desde 1813 y en las que narra a su modo los acontecimientos caraqueños en los que tuvo parte Casa León [el marqués de Casa León, su hermano Antonio]; no hemos tenido más noticias sobre estas memorias, ni hemos podido averiguar su existencia, posiblemente sea una confusión con el escrito que realiza ahora Don Esteban y que venimos citando» (80).
} 


\section{3. [*154]. FERNÁNDEZ DE MORATÍN, LEANDRO}

—Fragmento de la vida de Moratín, escrito por él mismo. En Leandro Fernández de Moratín. La comedia nueva. Comedia en dos actos estrenada en el Teatro del Príncipe. Madrid, 7 de febrero, 1792. Edición con introducción, notas y documentos de John Dowling. Madrid: Editorial Castalia, $1970,19-22$.

Ésta es la única edición moderna de la autobiografía fragmentaria de Moratín, que se me pasó en el Catálogo de 1997, obra de John Dowling, quien la presenta como «el encantador fragmento de una autobiografía que se publicó ya en las Obras póstumas de Moratín donde ha quedado desconocida para muchos lectores» (17). Lo edita, al parecer, considerando el manuscrito original de la $\mathrm{BN}^{37}$.

\section{FERNÁNDEZ DE LOS RÍOS, ÁNGEL}

(Madrid 1821 - París 1880. político, periodista y escritor progresista. Ocupó numerosos cargos en esos ámbitos, fue director de varios periódicos y fundador del Semanario Pintoresco Español. Fue embajador en Lisboa durante el Sexenio.)

—Mi misión en Portugal. Anales de ayer para enseñanza de mañana. París - Lisboa: E. Belhatte Bertrand, s. a. [h. 1877] (XVI + 725 pp.) $)^{38}$.

Fernández de los Ríos fue enviado a Lisboa con la dura tarea de negociar la corona española para el rey de Portugal. Abre su testimonio con un prólogo «A la opinión peninsular» (V-XVI), en que desarrolla su idea de la representación de los embajadores: el de un rey sólo se debe a éste pero el de una nación soberana ha de dar cuenta ante el pueblo, de ahí que escriba este libro. Intentó publicarlo con los documentos oficiales desde el primer momento, pero la Restauración borbónica le ocasionó destierros y

${ }^{37}$ Este precioso amago de autobiografía no había despertado el interés crítico, pero recientemente le he dedicado un estudio extenso en mi citada tesis doctoral y se ha publicado también un artículo sobre él: José María Rodríguez García. «Las autobiografías de Jovellanos y Moratín (con un apunte sobre Swift)». Iberoromania (Tubinga, Alemania), 55 (2002), 60-79.

${ }^{38}$ En Portugal hubo réplica a este libro: Luís Augusto Palmeirim. Portugal e os seus detractores: reflexies a proposito do livro de Sr. Fernández de los Ríos intitulado «Mi misión». Lisboa: Typ. da Bibl. Universal de Lucas \& Filho, 1877 (XII + 354 pp.). también: A uni,o iberica, e a candidatura d'el-rei D. Fernando. Resposta ao livro do sr. Fernández de los Ríos, Mi mission en Portugal. Por Antonio Rodrigues Sampaio, Eduardo Coelho, Luciano Cordeiro e Pinheiro Chagas. Lisboa: Off. Typ. de J. A. de Mattos, [h. 1877] (199 pp.). 
detenciones. Exiliado en París, acopió todos sus materiales, incluidos diarios personales, y escribió apresuradamente este extenso libro, que ya antes de aparecer causó revuelo en la prensa portuguesa. La primera parte: «Política peninsular» (1-240) tiene capítulos por épocas (1140-1640, 1640-1800, un balance de todo lo anterior, 1808-1869 y un nuevo balance); es una erudita recapitulación de las relaciones hispanoportuguesas desde la fundación del reino de Portugal hasta 1868. La segunda parte es la memorialística: «Mi misión en Portugal. 1869-1874» (241-670), detalladísimo relato de su embajada en Portugal y de todos los diversos asuntos de los que se ocupó.

Tiene una compleja división que no vale la pena especificar, pero que sigue criterios cronológicos y temáticos. Comienza con esta frase: «La noche del 13 de enero de 1869 fui llamado con toda urgencia por el Sr. Zorrilla» (241), tras la que fluye un hilo cronológico de narración — siempre acompañada de comentarios y discusiones polémicas- que se interrumpe para insertar centenares de documentos, a veces sólo con breves pasajes de transición. La tercera y última parte es «Cuestiones de hoy y de mañana» (671-725), y se dedica a narrar los últimos sucesos que coronan todo el periodo. «Mi destierro de España», «Mi destierro de Portugal», y reflexiones sobre la actualidad política. El meollo del libro consiste en defenderse de la acusación de iberista a ultranza que han vertido contra él tanto en Portugal como en España aunque escrita en caliente, combina el propósito apologético, el documental y el histórico, como en muchas otras memorias políticas de la segunda mitad del XIX.

\section{5. [*158]. FIGUEROA Y TORRES, ÁLVARO DE}

—Notas de una vida. Madrid: Marcial Pons, 1999 (XXXIX + 552 pp.).

Edición nueva en un solo tomo de las memorias del conde de Romanones.

\section{FOURNIER GONZÁLEZ, GERVASIO}

(N. en Burgos 1842. Miembro de una familia de litógrafos, de joven trasladó su negocio a Valladolid. Al mismo tiempo, desarrolló de modo autodidacta estudios en historia y geografía del mundo antiguo, sobre lo cual publicó controvertidas teorías. Fue socio y colaborador de varias academias y universidades.) 
—Su autobiografía, acompañada de un extenso apéndice bibliográfico de sus obras y de muchas cartas de académicos, catedráticos, publicistas y amantes del saber de España y del extranjero. Valladolid: Tipolitografía de E. Castañeda, 1917 (CCX + 291 pp.).

$\mathrm{Al}$ menos existe este libro en la biblioteca pública de Burgos, que no he visto; en la biblioteca del Palacio Real de Madrid se conserva un curioso ejemplar incompleto, con fecha de 1916, de solo XVI + 176 pp.; al final de cada bloque se encuadernan unas hojas escritas a mano, se supone que por el mismo Fournier: «falta imprimir la continuación, que hará 8 ó 10 pliegos» (tras la paginación romana) y «falta imprimir el resto del apéndice, que subirá a 20 pliegos o más, por las numerosas cartas que tengo del tomo publicado por el Estado» (tras la paginación arábiga). De esta versión mutilada poco puede decirse: tiene una dedicatoria a su esposa y un prólogo al lector, ambos fechados en 19-X-1916. Su propósito es reivindicar su aportación a la ciencia histórica, que considera injustamente postergada: en este libro agrupa los avales que acreditan su altura intelectual, como reseñas, cartas y elogios (forman el extenso apéndice en numeración árabe); precede a esto una autobiografía, que en el ejemplar incompleto comprende sólo parte del capítulo I: «Origen de mis aficiones artísticas y geográficohistóricas, obras publicadas y juicios emitidos por una gran parte de la mentalidad española que figuran en el Apéndice», en el que explica su nacimiento, ensalza el legado moral recibido de sus padres y cuenta los sucesivos oficios y estudios que fue desempeñando y cómo fue formando sus ideas históricas. Pretende, pues, configurarse como autobiografía intelectual.

\section{7. [*170]. GALLARDO DE MENDOZA ${ }^{39}$}

(Almería 1788 - ¿París? 1860. Militar. En 1808 se alistó en las tropas patriotas; estuvo en Bailén y operó hasta 1811 en Cataluña y Aragón. Hecho prisionero, aceptó incorporarse al ejército de Napoleón, pero sin combatir contra españoles. Desde 1812 hizo la campaña de Rusia y se batió en Alemania. Luego se quedó en el ejército francés y adquirió la ciudadanía. En 1823 entró en España con los Cien mil hijos de San Luis.)

${ }^{39}$ He podido consultar, gracias a la amabilidad del profesor Alberto Gil Novales, un ejemplar del texto íntegro de las memorias de Gallardo de Mendoza, que me permite superar la pobre y en parte incorrecta noticia que incluí en mi Catálogo de 1997. Sigue faltando el nombre propio del personaje, que no es citado en momento alguno de la obra, única fuente de las notas que aquí principio. 
- Mémoires du major Gallardo de Mendoza. Trascritti di sull'autografo dal sig. Am. Chenu, genero dell'autore, e comunicati dal prof. R. Peyre. En Miscellanea Napoleonica a cura di Alberto Lumbroso. Serie III-IV. Roma: Modes e Mendel Editori, 1898, 343-450.

Estas memorias se escribieron en francés y para franceses. La presentación de Lumbroso - que también firma las notas en italiano al texto- dedica corto espacio a la obra de Gallardo, facilitada para esta colección de inéditos sobre las guerras napoleónicas por el yerno del militar español, Amedée Chenu, quien transcribió el manuscrito y lo cedió a su familiar, el historiador Roger Peyre, para que añadiese un breve prólogo en francés (345-347). Es un texto corrido en orden cronológico, aunque el editor ha colocado entre corchetes los años y fechas que se suceden. Comienza con el nacimiento y concluye en 1816, cuando obtiene un destino militar en provincias y la nacionalidad francesa: «Ici je termine, avec l’Epopée Impériale, la première partie de ma vie militaire» (443). No obstante, hay luego otro trozo, presentado como «Appendix», que atañe a la revolución de 1830 y que carece de preámbulo alguno. Esto hace sospechar que lo publicado formase parte de una obra mayor sobre la vida militar de Gallardo, de la que no se consideraron históricamente valiosas las otras partes. Pero es pura conjetura.

En el escrito hay dos bloques: su servicio de armas en el ejército español entre 1808-1811 (348-380, sumado al breve preliminar sobre 1788-1808); y sus campañas bajo Napoleón en Alemania, Polonia, Rusia y Francia entre 1811-1816 (380-449). El brevísimo relato genealógico, de infancia y de estudios, junto a otros rasgos del contenido, hace ver en el autor una vocación autobiográfica por encima del testimonialismo histórico; aunque proporciona bastante información sobre los episodios militares, los narra desde su limitada atalaya personal, seguramente empleando un diario de campaña u otra documentación. Tiene la típica mentalidad del autobiógrafo moderno que contempla con nostalgia y perplejidad el devenir de sus años mozos desde una ancianidad serena y sumido en una intensa conciencia del tiempo y del yo. El estilo narrativo es directo y sin adornos, con una visión muy panorámica, ribetes humorísticos y huyendo de idealizar el pasado bélico. Su sentido crítico le impide adoptar una visión nacionalista y glorificadora: insiste en las penalidades, se queja de los errores de los mandos..., hambre, fatiga y nada de gloria es lo que rebosa su memoria, pero no con amargura, sino con añoranza de la juventud. Un detalle muy característico que le aparta de sus coetáneos memorialistas españoles y le aproxima a una mentalidad francesa, es el 
gusto por los contenidos galantes. El autor recobra el recuerdo emocionante de unos años de aventura, vigor físico, giros increíbles de su destino, pero también marcados por el gozo carnal, al que atiende una y otra vez con cierta sorna picarona.

\section{GALOBARDES, JAUME}

(Santa Coloma de Gramanet, Barcelona, 1766 - Santa Coloma, 1863. Campesino, viticultor y tratante de vinos.)

—El llibre de Jaume Galobardes (1776-1863). Crònica del seu temps, Ramón Sagués i Baixeras (ed.). Santa Coloma: Museu Torre Balldovina, Ajuntament de Santa Coloma de Gramenet, 1992 (223 pp.). Prólogo de Carles Viñas i Serra ${ }^{40}$.

Fuera del ámbito local y familiar, Jaume Galobardes no ocupó ninguna posición social reseñable: fue uno de los muchos campesinos catalanes con la suficiente instrucción, hábito lector y curiosidad hacia el mundo a su alrededor —era una cultura superficial, de lecturas religiosas, prensa diaria y tradición oral—, como para inducirle a escribir una de esas extensas piezas que conocemos como libros de familia en el ámbito de la autobiografía «popular». Su grueso manuscrito se preservó en manos de sus descendientes hasta que en 1990 fue cedido al Museo Torre Balldovina para su restauración y edición: de ese trabajo es fruto el excelente libro de 1992 (31-148, el texto) ${ }^{41}$. En cierto momento empieza a escribir también su hijo Joan, que luego lo continúa. Es un volumen redactado a lo largo de muchos años; guardaba huecos para ampliaciones, pero a menudo tiene que escribir al margen o reenviar a un lugar posterior por falta de espacio. El autor, por tanto, distinguía las diferentes partes y contenidos de su libro de apuntes, según sus varias funciones. Incluye largos bloques de oraciones y textos religiosos, omitidos de la edición de 1992, en la cual los editores han reordenado las secciones que en el autógrafo figuran ligadas con reenvíos: una crónica de sucesos

\footnotetext{
${ }^{40}$ Es un libro de gran formato, con reproducciones copiosas y a todo color de numerosas páginas del manuscrito, además de fotografías.

${ }^{41}$ El manuscrito era, sin embargo, conocido desde que lo estudió el historiador local de Santa Coloma, Joan Vilaseca i Segalés, en el folleto Llibre de Jaume Galobardes de Santa Coloma de Gramanet (1817-1863). Santa Coloma de Gramanet, 1973 (previamente publicado en el Butlletí de la Secció d'Estudis del Centre Excursionista Puig Castellar en la misma ciudad, segunda época, números 27 y 9-12; abarca unas 65 páginas que, al parecer, transcriben fragmentos del texto con algunos comentarios que se incluyen como apéndice en el libro de 1992, 203-215).
} 
en Santa Coloma y en toda Cataluña, casi siempre crímenes, en secuencias sueltas (3142, en su mayoría de los años 1850); una gran reconstrucción histórica desde 1790 en adelante, con énfasis en la Guerra de la Independencia y las carlistas en el ámbito catalán (42-79, parece escribirse en 1842 y en 1854, con actualizaciones); anotaciones con motivo de sus cumpleaños, enumeraciones de los ayuntamientos de Santa Coloma y asuntillos locales; cuentas de la casa, tablas de gastos, datos de cosechas, incidencias y metereológicas (esta parte llega hasta el 1862); una nueva recapitulación histórica, escrita a los 86 años, más resumida que la anterior (88-90); datos sobre los avances del ferrocarril y otras asombrosas señales del progreso de los tiempos (90-92); y otros muchos fragmentos mixtos, de contenido menos clasificable.

La sección que me interesa comienza en el folio 521 del manuscrito: «Notícia de mon llinatge, és que en el principi de la centúria de 1700 s’aposenta un tal Jaume Galobardes en aquest poble de Sta. Coloma de Gramenet, i aquest tal fou casat amb Maria Sardł» (98). Igual que anota cuanto de interés pasa en sus tierras y casa, lo que ocurría en su entorno vecinal y regional, y recapitula la historia política de su tiempo, el anciano Galobardes dedica una evocación retrospectiva a su propia vida. Empieza con una detallada crónica de los pasos, matrimonios, nacimientos y mejoras de su familia desde ese primer antepasado conocido (98-101). Esa parte se escribió en 1817, con actualizaciones en 1819 (en otros lugares las adiciones son más tardías: 1837...); esta temprana fecha puede hacer sospechar que el núcleo inicial de su libro fuese precisamente esta historia familiar. El relato es secamente informativo; no obstante, al llegar a su nacimiento, indica: «En quant jo, Jaume Galobardes, per línia recta hereu i el major dels Galobardes d'aquest poble de Sta. Coloma de Gramenet, tota la meva vida l'he passada amb tribulació i grans malalties que he tingut» (101), aunque desarrolla poco esa desdichada condición que se atribuye. Cuenta la enfermedad y muerte del padre con gran sentimiento, quizá como uno de los ejes reconocibles de su vida, que solemniza con resignación cristiana. «Trobant-me jo quan morí mon pare d'edat de 38 anys, què puc esperar d'aquesta vida? ...s tribulacions, malalties, xacres, avorrit i altres miserias, a cas envellir a una edat regular. I en això demano a Déu que dirigeixi tots els meus pensaments a major honra i glòria seva i a bé de ma ánima i també paraules i obres» (105). A partir de aquí pasa a hablar de su matrimonio, que le lleva otro buen trozo muy circunstanciado de texto, así como de un asalto que sufrió con grave peligro de muerte. Otro tema recurrente son las enfermedades. Este relato concluye con su boda 
y nacimientos de sus primeros hijos, lo que le lleva hasta 1820 (110). Desde aquí sólo hay actualizaciones más o menos breves y formulísticas, fechadas siempre «hoy» (y días concretos de 1823 a 1829), hasta los años 50.

\section{9. [*178]. GARCÍA DE LEÓN Y PIZARRO, JOSÉ}

—Memorias, Álvaro Alonso-Castrillo (ed.). Madrid: Centro de Estudios Políticos y Constitucionales («Clásicos del pensamiento político y constitucional español»), 1998 (XVII + 773 pp.).

Nueva reedición de estas importantes Memorias, que reproduce la anterior de 1953.

\section{0. [*192; **14]. GÓMEZ DE AVELLANEDA, GERTRUDIS}

—Diario de amor, Bernardo Callejas (ed.). La Habana: Editorial Letras Cubanas («Colección Saeta», 156), 1993. Segunda edición de un volumen publicado en la misma editorial en 1981, en otra colección.

—Sab and Autobiography, Nina M. Scott (ed. y trad.). Austin: University of Texas Press («The Texas Pan American Series»), 1993 (XXVII + 157 pp.).

-Autobiografía y epistolarios de amor. Edición, introducción y notas de Alexander Roselló Selimov. Newark: Juan de la Cuesta Hispanic Monographs, 1999 (IX + 288 pp.). Prólogo de Russell P. Sebold («Un Espíritu romántico desdoblado en dos tiempos», 1-6). Reedición corregida en $2001^{42}$.

-En Meri Torras. Soy como consiga que imaginéis. La construcción de la subjetividad en las autobiografías epistolares de Gertrudis Gómez de Avellaneda y Sor Juana Inés de la Cruz. Cádiz: Publicaciones de la Universidad de Cádiz («Textos y estudios de mujeres. Serie 2», 6), 2003, 145170.

Más ediciones de la autobiografía amorosa y una traducción al inglés, no tenidas en cuenta antes y que han de incorporarse a la ya larga lista de publicaciones de una pieza que no deja de mostrarse como una de las más productivas, sugerentes y fascinadoras de la autobiografía decimonónica hispánica.

\footnotetext{
${ }^{42}$ Se edita el texto una vez más en unión con varios epistolarios amorosos, precedido de un extenso estudio en que aporta una nueva interpretación de estas cartas. Véase mi reseña de esta edición en Cuadernos de Ilustración y Romanticismo, 9 (2001), 241-244.
} 


\section{GONZÁLEZ HURTADO, DEOGRACIAS}

(Hinojal, Cáceres, 1874 - Santiago del Campo, Cáceres, 1936. Hijo de un herrero, con estudios primarios, en 1894 fue llamado a filas. Como sargento se presentó voluntario en 1896 para combatir en Filipinas. Al final de la guerra, fue hecho prisionero por los filipinos, en cuyo poder permanece hasta su vuelta en 1900 a España. Regenta un comercio en Santiago del Campo el resto de su vida.)

- La pérdida de Filipinas narrada por un soldado extremeño (1896-1899). Memorias del sargento Deogracias González Hurtado, Julián Chaves Palacios (ed.). Mérida: Editora Regional de Extremadura, 1998 (206 pp.) $)^{43}$.

El texto autobiográfico posee tres partes: servicio bélico en Filipinas como cazador, etapa como prisionero de guerra y, mucho más breve, su repatriación a España. No se ofrece ninguna noticia sobre cuándo se escribió, aunque las dos primeras partes forman un único documento corrido, mientras que la tercera procede de un documento diferente y es sólo un guión para una redacción futura, que no se sabe que llegara a hacerse. En general el autor muestra una expresión correcta, aunque siempre en el plano de la narración directa de lo vivido, lo que le aproxima a la autobiografía «popular». Toda su vida tuvo afición a escribir, y seguramente fue lector de periódicos, con conciencia del valor de la cultura, fuese cual fuese su acceso real a ella. En su relato cuenta que en Filipinas le «veían escribir alguna carta o notas particulares que solía apuntar» (168). El relato es asimismo muy proporcionado en días y horas, lo que suele ser síntoma de un diario previo. Su estilo vivaz desvela una personalidad observadora, pero que no quiere impresionar ni por la altura literaria, que no posee, ni por sus opiniones, que brillan también por su ausencia. Las memorias comienzan sin ningún tipo de preámbulo con su designación para ir a Extremo Oriente, punto de partida de un ininterrumpido relato lineal de la experiencia bélica. No interpreta apenas los hechos que narra, ni tampoco insiste en sus impresiones sobre el país, la política o la guerra: es una pura y fría

\footnotetext{
${ }^{43}$ El volumen, de gran calidad tipográfica, incluye notas del editor y abundante material fotográfico sobre el autor, Filipinas y la guerra. Consta de una introducción histórica de Chaves Palacios acerca del memorialista y del conflicto hispano-filipino (15-75), texto de las memorias (77-183) y apéndices documentales (185-206). Los apéndices proceden de los papeles conservados por los herederos del autor junto con el manuscrito de las memorias: hoja de servicios, listas de compañeros de armas en Filipinas, poemas, etc. Chaves Palacios añade un resumen biográfico de la vida de González Hurtado desde 1900 hasta su muerte.
} 
narración, que no penetra en la realidad filipina o en la naturaleza del conflicto. Su principal valor es justo esa naturalidad realista con que cuenta los detalles cotidianos de la vida castrense, sin idealizarla ni criticarla, y sin traslucir tendencia ideológica alguna, mezclando con la misma facilidad y falta de énfasis las enfermedades, los tedios y las borracheras, junto a una visión feroz de los combates: «Tras ese suceso se procedió al fusilamiento de todo el que se libró de las llamas. Una vez terminado, se establecieron avanzadas, o mejor dicho, recintos, sosteniendo un fuego constante los trece días que allí estuvimos, siendo bastantes las bajas que nos causaron» (100). Sólo en la segunda parte, cuando era prisionero y la guerra estaba perdida, se trasluce una imagen algo más compleja y con algún tinte crítico y regeneracionista, pero sin perder su conciencia colonial y despreciativa respecto a los filipinos (los «indios»).

\section{2. [*197]. GONZÁLEZ MATEO, SANTIAGO}

—Vida trágica de D. Santiago González Mateo, Job del siglo XVIII y XIX (1809), Javier Pérez Escohotado (ed.). Logroño: Instituto de Estudios Riojanos («Filología», 13), 2001 (152 pp.).

Se ha producido la primera publicación en libro de la extraordinaria Vida trágica del beneficiado de Laguardia. Se realiza a partir de la edición de 1917 de Galo Sánchez, sin contar con el manuscrito original, aunque sí incorpora notas y un interesante estudio $\operatorname{preliminar}^{44}$.

\section{GONZÁLEZ TORRES DE NAVARRA, LUIS}

(Marqués de Campo Verde, conde de Santa Gadea. Fue uno de los destacados jefes militares de la Guerra de la Independencia, al mando supremo de Cataluña durante la primera mitad de 1811, en un momento de duros combates en la región y con una controvertida actuación política y militar. Fue destituido).

\footnotetext{
${ }^{44}$ González Mateo es uno de los autores a los que más espacio dediqué en mi citada tesis doctoral de 2001; aparte de un estudio e interpretación muy extenso, con una reconstrucción de la biografía del autor, incluí también una edición del texto a partir del manuscrito original, con numerosas notas. En amplios apéndices se vacían los numerosos materiales de archivo que están disponibles sobre el beneficiado y su hermano Judas Tadeo, en particular expedientes inquisitoriales. Es mi intención publicar en breve todo ese material, del que una pequeña parte, en lo referido al hermano, la he publicado en este artículo: «La Ilustración boca a boca: el profesor Ramón de Salas y su discípulo Judas Tadeo González Mateo». Trienio. Ilustración y liberalismo, 41 (2003), 25-53.
} 
—Exposición de la conducta que ha observado el Mariscal de Campo de los Reales Ejércitos marqués de Campoverde, Conde de Santa Gadea, en la época que obtuvo el mando de Jefe interino del Ejército y Provincia de Cataluña, y noticias exactas de lo ocurrido en el sitio de Tarragona. Alicante: Nicolás Carratalá menor y hermano, 1811 (84 pp.).

Es un apretado manifiesto justificativo al estilo habitual. Empieza con esta «Nota»: «Como el objeto que me propongo en la publicación de este papel no es el de patentizar mis servicios, sólo hablaré de las ocurrencias del Principado en el tiempo que obtuve interinamente el mando» (2). Tras la exposición (3-26) hay un apéndice con 32 documentos (27-84). La narración cubre desde que asume el mando, entre 6-I y 9-VII1811; es un relato rápido y denso, muy abreviado y persistentemente autolaudatorio, pero sin excesivo espacio para discusiones y comentarios. Se ocupa de los hechos bélicos y de sus relaciones con la junta catalana y las otras autoridades civiles y militares; más de la mitad se consagra en exclusiva a las incidencias del sitio de Tarragona, uno de los hechos de guerra más polémicos y desgraciados de su mandato ${ }^{45}$.

\section{4. [*206]. GUERRA Y PE-A, LOPE ANTONIO DE LA}

—Memorias. Tenerife en la segunda mitad del siglo XVIII. Estudio y notas Enrique Romeu Palazuelos. Las Palmas de Gran Canaria: Ediciones del Cabildo Insular de Gran Canaria («Colección Ínsulas de la Fortuna» 7), 2002 (783 pp.).

Segunda edición, refundida en un solo volumen, del texto que dio a luz en 19511959 Simón Benítez. Se añaden nuevo prólogo y notas a los de la edición original.

\section{HERNÁNDEZ-ARDIETA, JOSÉ ${ }^{46}$}

(Torre Pacheco, Murcia, 1838-1912. Sacerdote y licenciado en física y química, desarrolló pronto dudas y luego ideas librepensadoras y anticlericales. En 1873 la

\footnotetext{
${ }^{45}$ Véase en este mismo trabajo la entrada sobre Antonio Coris, uno de sus firmes partidarios. Hubo varias réplicas al general: Dos palabritas al marqués Campoverde. Carta de un español contestando a su exposición publicada en Alicante. Palma de Mallorca: Imprenta de Brusi, 1811 (27pp.). Representación del coronel de los Reales Ejércitos y Gobernador militar y político interino del corregimiento de Gerona Juan Clarós a S. A. el Consejo de Regencia sobre la Exposición que contra él hizo el marqués de Campoverde. Vic: Oficina de Juan Dorca, 1812 (84 pp.). El despotismo confundido por sí mismo. Respuesta a la representación que contra el mariscal de campo don Francisco Milans inserta en su exposición el general marqués de Campoverde. Vic: 1812 (46pp.).

${ }^{46}$ Para su localización conviene saber que solía firmar a veces como H. Ardieta o con seudónimos.
} 
revolución cantonal de Cartagena, que apoyó, le desvincula del catolicismo. Escapa a Argelia y Portugal, donde se casa. Entre 1873-1884 tomó parte en una fracasada colonia utópica en los Andes bolivianos. Regresa a Murcia y funda el periódico El libre pensamiento, que provoca su excomunión. En 1904 abjuró de sus ideas y retornó al seno de la Iglesia en Barcelona.)

-Conflictos entre la razón y el dogma o memorias íntimas de un librepensador. Por H. Ardieta. Barcelona: La Enciclopedia Democrática, Casa Editorial de Román Gil, 1894-1895 (2 vols.: XXVII + 787 / 800 pp.).

José Hernández-Ardieta fue autor, traductor y adaptador de varios libros de propaganda ideológica, higienismo, medicina y teología, además de activo periodista en la prensa progresista y anticlerical. Su inquietud espiritual y su peripecia le vinculan a otros reformistas religiosos de la España del XIX: un carácter no poco atrabiliario y mesiánico, pero con una meritoria tendencia al autoanálisis y a la búsqueda de la verdad siguiendo el dictado de una conciencia libre. Como casi todos ellos, también dejó testimonio autobiográfico de su periplo moral, aunque les superó en la magnitud literaria de su esfuerzo, dos voluminosísimos tomos, tan densos en el contenido como verbosos en la forma.

Sus Conflictos están dedicados a sus hijos. El prólogo (VII-XIX) desentraña la eterna «lucha entre la razón humana y las imposiciones de los dogmas religiosos» y de las «castas sacerdotales [...], asociaciones de hombres astutos, dominadores y ambiciosos, que poniéndose bajo la salvaguardia de misteriosos poderes sobrenaturales, han tratado, en nombre del cielo, de hacerse dueños de la tierra» (VII). Denuncia el poder de la Iglesia, y en particular de los jesuitas, y anuncia que el fin de la teocracia se aproxima: «La idea es superior al oro y a la plata; la razón humana es más poderosa que las empresas mercantiles [...]. Venceremos nosotros, los pobres, los perseguidos, los insultados. [...] El presente libro es demostración práctica de esta teoría. El que lea sus páginas aprenderá el camino que sigue la razón humana para emanciparse de los absurdos religiosos» (XVIII-XIX). Siguen unas «Declaraciones previas » (XXI-XXVII) que funcionan como pacto autobiográfico, en el que argumenta que con la vejez sentía necesidad de reposar y de transmitir sus recuerdos a amigos y familiares, así como de convertirlos en una enseñanza pública. 
El relato consta de setenta extensos capítulos, siempre prolijos, circunstanciados y llenos de diálogos y descripciones. Su peor defecto es la continua digresión doctrinal sobre cualquier cuestión filosófica, religiosa, científica, social, política, etc. que se cruce. Eso hincha el libro con ideas recurrentes argumentadas y ejemplificadas hasta la saciedad. Por lo demás, el hilo narrativo sigue un orden más o menos cronológico, aunque sin gran rigor, entreverado con esas disquisiciones ensayísticas. En conjunto da razón de su infancia y juventud, sus relaciones con políticos y periodistas, sus propias labores en ese terreno, las conspiraciones antes de la Revolución, todo mezclado con la historia colectiva y muchísima historia privada. El primer tomo abarca aproximadamente de 1868 a 1873. El eje es la crisis religiosa que le conduce al abandono del sacerdocio para casarse por lo civil, así como a convertirse en un político radical durante el Sexenio; los últimos capítulos cubren su estancia lisboeta y los preparativos para acudir a Sudamérica. El segundo tomo se consagra monográficamente a la utópica colonia Progreso en el mismo estilo de sermón laico. Concluye con un «Epílogo» (775-794), en que muestra el retroceso acontecido en España desde su marcha. Pese a todo, asegura que el triunfo del librepensamiento y la razón frente a la teocracia y al dogma están cerca. La nota más característica del libro es su intenso tono subjetivo, ya que habla siempre más de sus ideas y sus sentimientos que de sus hechos; todo el relato está enfocado a mostrar su evolución interior, sus dudas, convicciones, esperanzas, amores y emociones. En ese sentido, y en la línea de los autobiógrafos espirituales españoles del XIX, es una autobiografía íntima que merecería una lectura y estudio pausados ${ }^{47}$.

Bibliogr.: Juan GARCÍA ABELLÁN. «El librepensador don José Hernández Ardieta. Episodio de su excomunión», Murgetana, 48 (1977), 29-66 / José Luis Molina Martínez. Anticlericalismo y literatura en el siglo XIX. Murcia: Universidad de Murcia, 1998, 207-210.

47 Varias fuentes mencionan un libro, que no he podido ver, pero de cuyas descripciones se desprende una posible dimensión autobiográfica: Historia de una excomunión. Episodio de la lucha contemporánea entre el librepensamiento y el clericalismo por J. H. Ardieta. Murcia: Tip. de Rafael Albadalejo, 1886 (77 pp.). Al parecer, contiene una narración de su entrevista con el obispo de Murcia, previa a su excomunión, que ya había publicado en El libre pensamiento, junto con una serie de veinte cartas al mismo prelado replicándole en términos teológicos, canónicos, filosóficos, etc. Por último, se menciona también esta otra obra, cuyo título sugiere idéntica posibilidad: El excomulgado o la boda de un presbítero. Madrid: Juan Muñoz Sánchez, s. a. [1886?]; forma parte de la Biblioteca del Renacimiento Literario, avanzada colección consagrada a anticlericales, librepensadores y naturalistas radicales. 


\section{6. [*224]. HORTELANO VALVO, BENITO}

—Memorias de Benito Hortelano (parte argentina). 1849-1860. Buenos Aires: EUDEBA [Editorial Universitaria de Buenos Aires] («Biblioteca de divulgación. Colección Siglo y Medio», 121), 1973 (191 pp.).

Edición parcial del libro de memorias publicado en Madrid el año 1936.

\section{IRIARTE, JUAN DE}

(Puerto de la Cruz, Tenerife, 1702 - Madrid 1771. Humanista, gramático y bibliotecario de la Real Biblioteca en Madrid. Miembro de una influyente familia de escritores y políticos canarios afincados en la corte, se educó en París.)

-[Autobiografía latina inacabada, comenzada en 20 de enero de 1762], manuscrito autógrafo en pp. 155-170 de un volumen misceláneo titulado Noticia de la vida y literatura de D. Juan de Iriarte, $y$ documentos y cartas relativos a su persona y empleos y estudios... (571 pp., 17 ‘ 22’5 cm., varios papeles de diferente tamaño cosidos juntos y encuadernados en cartón, serie Cartas de la familia Iriarte, vol. II), Biblioteca Bartolomé March Servera (Palma de Mallorca), sign. B99-A$10(2)^{48}$.

El relato está en borrador, con letra maltratada, y comienza así (Salas): «Natus itaque sum in insula olim Niuaria, nunca Tenerife. Fortunatarum post Canariam illarum caput, praecipua, in Portu Orotauensi alias Crucis anno uidelicet MDCCII die Decembris 15». Es una narración de corte intelectualista, centrada en sus estudios de infancia, pero requeriría una edición íntegra y directa para poder emitir un comentario fundado $^{49}$. Este embrión autobiográfico fue el material del que se sirvió su sobrino Bernardo para biografiar a su pariente y protector en su Noticia de la vida y literatura

${ }^{48}$ Cuando esta biblioteca estuvo en Madrid, tenía la signatura 14-1-4(III); antes perteneció a otro fondo de papeles de Thomas Philips, sign. 10790. La biblioteca March contiene un lote de manuscritos de la familia Iriarte, incluyendo apuntes, correspondencia, etc., algunos volúmenes tienen títulos facticios parecidos al que me interesa, que conviene no confundir. Hay referencias confusas, con encabezamientos diferentes, en Aguilar Piñal, Millares Carlo y otras fuentes generales o particulares, pero hoy por hoy la más completa y actualizada es la de Salas (311-313).

49 Tengo previsto publicar próximamente un estudio, edición y traducción del manuscrito autobiográfico, junto con María del Carmen Ramos Santana. 
de D. Juan de Iriarte. s. l.: s. i., s. a. (29 pp.) ${ }^{50}$. Así lo explica: «Entre los muchos escritos y apuntaciones eruditas que ha dejado D. Juan de Iriarte [...] son rarísimos los documentos relativos a su persona que existen; pero se ha encontrado uno que pudiera suplir el defecto de todos, si como es un mero fragmento, le hubiese llevado a debida perfección, o continuándole en parte. Redúcese éste a un principio de su propia vida en latín [...] en que, con interrupciones, se lee difícilmente algo tocante a sus niñeces y primeros estudios, dejándonos el sentimiento de que no se hubiese extendido, a lo menos, a informar de todos los que cursó en Francia, y que fueron basa de su profunda erudición. Recogiendo las posibles noticias y recapacitando las especies sueltas que su desprendimiento de sí propio y su modestia le permitieron comunicar a los sujetos de su más íntimo trato y confianza, se intentará dar una idea de los estudios, empleos, trabajos literarios y cúmulo de prendas que le adornaban, adaptando oportunamente cuanto se deduce de dicho fragmento» (2). Entre las pp. 3-6, en efecto, maneja el material autobiográfico, traduciendo entre comillas varios pasajes y copiando a la letra en nota el original latino. Las biografías de Juan de Iriarte que publicaron Sempere y Guarinos, Viera y Clavijo, etc., dependen estrechamente de esta de Bernardo de Iriarte.

Bibliogr.: Agustín MILLARES CARLO y Manuel HERNÁNDEZ SUÁREZ. Bio-bibliografía de escritores canarios (siglos XVI, XVII y XVIII). Las Palmas: El Museo Canario - CSIC - Cabildo Insular de Gran Canaria, 1975-1992 (6 vols., $2^{\text {a }}$ ed. ampliada del libro original de Millares) / Gregorio de Andrés. «El bibliotecario D. Juan de Iriarte». En Homenaje a Luis Morales Oliver. Madrid: FUE, 1986, 587-606 / Francisco Salas Salgado. Humanistas canarios de los siglos XVI-XIX. La Laguna: Universidad de La Laguna, $1999^{51}$.

\section{LACALLE, PAULINO DE}

(N. en Galapagar, Madrid, 1792. Dentista y cirujano liberal. En 1820 fue de la

\footnotetext{
${ }^{50}$ Este opúsculo, que aparece sin firma ni pie de imprenta, es de 1771, ya que en realidad se trata de una tirada aparte de un libro mayor, donde figura con paginación independiente: Gramática latina, escrita con nuevo método y nuevas observaciones, en verso castellano con su explicación en prosa. Madrid: Imprenta de Pedro Marín, 1771 (2 hs. + 29 pp. + VIII pp. + 560 pp.). Esta edición póstuma de la obra de Juan de Iriarte fue preparada por sus sobrinos, quienes también insertaron la Noticia de Bernardo, al parecer con alguna modificación, en el tomo I de las Obras sueltas de D. Juan de Iriarte, publicadas en obsequio de la literatura, a expensas de varios caballeros amantes del ingenio y del mérito. Madrid: Francisco Manuel de Mena, 1774 (2 vols.).

${ }^{51}$ Sobre Juan de Iriarte véase el $\mathrm{n}^{\mathrm{o}} 55$ (t. II, 140-346), con amplísima bibliografía primaria y secundaria; Salas tiene otros varios trabajos parciales sobre la obra humanística de Juan de Iriarte.
} 
milicia liberal y como tal en 1823 siguió al gobierno a Sevilla y Cádiz; regresó luego a Madrid, donde sufrió represalias: se le quiso implicar en el asesinato del cura Vinuesa. Estuvo varios meses preso y eludió la pena de muerte por una misteriosa fuga que le condujo a Inglaterra.)

— «Interesante narración de la injusta causa seguida en Madrid contra Don Paulino de Lacalle y del modo admirable en que fue arrancado de la prisión y puesto en salvo del suplicio afrentoso a que estaba condenado por la arbitrariedad de aquel gobierno. Escríbela él mismo en obsequio de sus libertadores en Londres a 27 de febrero de 1825». El Español Constitucional, o Miscelánea de política, ciencias y artes, literatura, etc. (Londres), 37 (marzo de 1825), 396-419, dentro de la «Sección tercera. Variedades».

Lacalle divulgó su aventura en la más agresiva de las publicaciones de los emigrados liberales de Londres. Justifica la escritura -dice- para tributar homenaje a quienes le ayudaron a huir y para hacer ver al mundo el heroísmo que aún fermenta en la abatida España. «Permítaseme un rasgo preliminar al acontecimiento que hace el asunto de esta narración. Deseando evitarme la aplicación del... gemino bellum trojanum orditur ab ovo, nada diré de mi vida anterior que no sea brevísimo y necesario» (397), y dedica un párrafo a explicar su nacimiento, estudios y costumbres hasta 1823 en que la política fue «origen de mis desgracias» (397); a continuación narra muy sucintamente sus actividades políticas como voluntario nacional en 1820-1823. Tras estos preliminares principia el relato vívido y muy circunstanciado de sus padecimientos como represaliado político. Su tono es indignado con sus perseguidores, a quienes nombra y denigra, pero huye del estilo patético y prefiere una redacción directa, en un formato que puede calificarse de periodístico. Insiste particularmente en el relato, muy novelesco y lleno de peripecias inverosímiles, de su fuga con la ayuda imprevista de una extraña sociedad secreta, que ocupa más de la mitad del total y es, obviamente, su razón de ser. Concluye anunciando su instalación como dentista en Londres, para no ser una carga a los benéficos ingleses, y para ello inserta un aviso publicitario con sus diferentes servicios profesionales ${ }^{52}$.

\footnotetext{
${ }^{52}$ Vicente Lloréns cree que es una narración «atractiva [...]. Es lástima que el autor no sacara mayor partido de las novelescas circunstancias de su huida, después de condenado a muerte por un delito que no había cometido, el mismo día señalado para la ejecución. Aun así hay momentos en que creemos estar leyendo alguna obra de Baroja. Lacalle no era por lo visto muy novelero, pero la joven y hermosa dama que preparó la evasión, en la cual el protagonista desempeñó un papel pasivo, sí que debió serlo»
} 


\section{LAVERDE RUIZ, GUMERSINDO}

(Estrada, Cantabria, 1835 - Santiago de Compostela, La Coruña, 1890. Catedrático en Lugo, Valladolid y Santiago; filósofo católico que participó en la polémica antikrausista. Su producción es escasa y dispersa, en parte por una enfermedad degenerativa que le aquejó los últimos treinta años de su vida.)

— «Autobiografía». En José María de Cossío (ed.), Gumersindo Laverde Ruiz. Antología de escritores y artistas montañeses XXIV. Santander:

Imprenta y Encuadernación de la Librería Moderna, 1951 (LXIX + 171 pp.), XI-XVII.

—En carta de Laverde a Menéndez Pelayo de 24-IV-1876: Epistolario de Laverde Ruiz y Menéndez Pelayo, 1874-1890, Ignacio Aguilera (ed.).

Santander: Diputación Provincial de Santander, 1967 (1 tomo en 2 vols.), 390-394. Prólogo de Sergio Fernández Larráin.

—Carta 10 de: Marcelino Menéndez Pelayo. Epistolario. Vol. 2, abril 1876 - diciembre 1877, Manuel Revuelta Sañudo (ed.). Madrid: Fundación Universitaria Española, 1982.

—En Menéndez Pelayo digital. Obras completas. Epistolario. Bibliografía. Madrid: Caja Cantabria - Fundación Histórica Tavera - Ayuntamiento de Santander — Digibis Publicaciones Digitales, 1999 (1 cederrón).

En la antología poética preparada por Cossío se recuperó un breve resumen autobiográfico: «conservamos su relato, hecho por el propio sujeto de ella con la misma sencillez de su estilo social. Se le envió a Menéndez Pelayo en ocasión de planear el gran montañés un estudio sobre la obra del poeta de Estrada, sin duda para la serie que proyectó sobre escritores de la Montaña. He aquí transcritos tales apuntes biográficos» $(\mathrm{XI})^{53}$. El texto consta de diez párrafos numerados, una nota a uno de ellos y una

(Liberales y románticos. Una emigración española en Inglaterra (1823-1834). Valencia: Editorial Castalia, 1979, 300).

${ }^{53}$ En realidad, estas notas se adjuntaron a una carta de Laverde a Menéndez Pelayo(Valladolid, 24IV-1876): «Le envío asimismo apuntes biográficos míos asaz minuciosos para que entresaque los datos que mejor le cuadren y no tenga que molestarme buscándolos cuando le llegue el caso de escribir mi necrología. ¿Tendrá algo de presentimiento esta prisa que ahora me doy a mandárselos?». La contestación (Santander, 27-IV-1876) dice: «Curiosísimas son las noticias biográficas que vd. de sí propio me comunica, y antes de mucho he de aprovecharlas no en su necrología (quos Deus avertat) sino en el estudio que he de dedicarle en mi galería montañesa. Viva vd. largos años para consuelo de sus amigos y gloria de las letras, y cuide de alejar de sí esos negros pensamientos y cavilaciones. [...] Para complemento de las noticias biográficas de vd. desearía un catálogo de los artículos, poesías, \& \& que dio a luz en periódicos y revistas no asturianos». La siguiente carta de Laverde (Valladolid, 30-IV-1876) adjunta una lista de diecisiete artículos suyos. Parece, pues, que no hubo una petición expresa de Menéndez Pelayo; ahora bien, en carta de 27-II-1876, Laverde le había sugerido hacer una colección de poetas montañeses antiguos y modernos, «tomando lo mejor de cada uno y añadiendo breves notas y 
posdata, todo formando un resumen puramente informativo. Los dos primeros párrafos dicen así: « $1^{\circ}$ Mis padres, don Toribio Laverde y Gil-Sanz, natural de San Vicente de la Barquera, abogado, y doña Asunción Ruiz de Lamadrid y Puertas, natural de Lavarces. $2^{\circ}$ Nací el 5 de abril de 1835 en Estrada, a tres kilómetros de San Vicente, donde mi padre era administrador del Conde de la Vega de Sella, actual cabeza de la ilustre familia de los Duque de Estrada (apellido)» (XI-XII). Los siguientes dan cuenta de sus estudios, progresos y tentativas literarias, cargos y destinos desempeñados, con algún que otro comentario suelto, casi siempre reducido a un adjetivo valorativo. Antes de la fecha y firma (Valladolid, 23-IV-1876), indica: «Y sigo afligido de los nervios» (XVII). La posdata añade un dato olvidado, cierta mención honorífica por una oda presentada a un concurso.

\section{LLINÁS Y DE ORTIZ-REPISO, JUAN ANTONIO DE}

(Militar. Estuvo con el ejército de La Romana en la Guerra de la Independencia, que hizo en el bando patriota. De ideas liberales, fue teniente coronel en 1815; en 1820 comandante de batallones de la milicia nacional voluntaria en Barcelona. Exiliado en 1823. En enero de 1836, tuvo un conflicto con el general Mina, que le expulsó de Barcelona.)

-Manifiesto del teniente coronel D. Juan Antonio de Llinás y de Ortiz-Repiso, capitán que fue del Real cuerpo de artillería y amnistiado en el día, con el fin de desvanecer las dudas que se hayan podido concebir relativas a sus hechos políticos o militares, a que puede haber dado lugar su destierro de Barcelona, siendo primer comandante del batallón de artillería de su guardia nacional, y lo que de él se dijo en la sesión del 12 de abril de este año en el estamento de señores procuradores. Valencia: Imprenta de López, 1836 (IV + 53).

La paginación romana corresponde a un prologuillo «A mis amigos», en que hace el habitual exordio sobre los agravios padecidos y su obligación de responder: «¡cómo vindicar mi conducta, cuando no se marca un hecho contra mi modo de obrar, sin recurrir a antecedentes invariables, los cuales convenzan de la falsedad que embeben las imputaciones que gratuitamente se me dirigen!» (I). En efecto, su justificación va a ser

sucintas biografías». En la lista que le apunta se incluye a sí mismo, de modo que probablemente le facilitó los datos con esa idea. 
de su persona en conjunto, no sólo de los hechos que se le imputan. El resto del prologuillo resume las acusaciones que se le imputaron. El relato en sí comienza trazando brevemente su trayectoria militar y política desde 1808: «Rompiendo las trabas y rasgando el velo con que mi nacimiento, la viciada educación española del siglo pasado, que me alcanzó aún, la superstición religiosa, el oropel del imperio militar, y mi propio interés me ofuscaran antes de poder desplegar mi razón, fui liberal por convencimiento desde mi juventud, afirmándome en las sanas doctrinas en el año 1807» (2). Resume a continuación sus sacrificios y servicios en favor de la libertad hasta 1836, sin ahorrar ponderación alguna. La segunda parte (21-40), que se fecha en Valencia, 21VI-1836, contiene la narración del conflicto con Mina, que se hace mucho más pormenorizada, casi en días y horas, y mucho más indignada, sin olvidar nunca el vector apologético que le motiva. Al final se sitúa el obligado apéndice documental con varias piezas $(41-53)^{54}$.

\title{
MARGARITA DEL ESPÍRITU SANTO
}

Véase: VALLE JIMÉNEZ, ¿MARGARITA? DEL

\author{
MARÍA DE SAN IGNACIO, SOR \\ Véase: ALONSO RECIO, MARÍA
}

\section{MARTÍN MATEOS, NICOMEDES}

(Béjar, Salamanca, 1806-1890. Filósofo neocatólico, cuya obra principal es El espiritualismo. Estudió derecho en la Universidad de Salamanca y de 1833 a 1843 ejerce como juez en localidades de Castilla y León; luego se retiró en Béjar, ocupado en la docencia y en empleos burocráticos, consagrándose al cultivo privado de la filosofía.)

\footnotetext{
${ }^{54}$ Sus quejas quedaron sin satisfacción, por lo que el grafómano Llinás martirizó las prensas con nuevas súplicas y protestas, casi siempre en el mismo pequeñísimo formato $\left(16^{\circ}\right)$ que el Manifiesto. Ninguna de estas referencias, algunas de las cuales no he podido confirmar, parece aportar nada nuevo desde el punto de vista autobiográfico: Confinamiento de Llinás, exposición a S. M. y ampliación con documentos. Alicante: E. Martínez, 1837. Última exposición que eleva a S. M. el Teniente Coronel Don Juan Antonio de Llinás. Alicante: Imprenta de Don N. Carratalá, 1837 (10pp.). Exposición que eleva al augusto congreso de Señores Diputados el teniente coronel Don Juan Antonio de Llinás... Alicante: Imp. de D. N. Carratalá, 1838 (18 pp.). Exposición que eleva al augusto Senado el teniente coronel D. Juan Antonio de Llinás. Alicante: Imprenta de D. N. Carratalá, 1838 (20 pp.). Extracto de la sesión del Senado del día 11 de mayo de 1838 y Exposiciones que eleva a las Cortes el teniente coronel D. Juan Antonio de Llinás. Alicante: Imprenta de D. N. Carratalá, 1838 (71 pp.). Tres exposiciones del ciudadano Llinás a las Cortes constituyentes. Valencia: Oficina de López, 183.
} 
— [Nota autobiográfica]. En Joaquín Egozcue Alonso. «Cartas de Martín Mateos a Laverde Ruiz y autobiografía de Martín Mateos (1864-1870)». Cuadernos salmantinos de filosofía, XXI (1994), 285-322 (texto en 310-318).

El manuscrito pertenece a un fondo documental de Gumersindo Laverde en la Biblioteca Menéndez Pelayo (Santander), sign. Laverde D 55, sobre 9: «Pequeño legajo de cuartillas ya descoloridas, con una escritura difícil» (301). Va unido a diez cartas de Martín Mateos a Laverde; los apuntes autobiográficos figuran tras la enviada en 24-IV1870 y su encabezamiento («D. Nicomedes Martín Mateos») es de mano de Laverde, quien sin duda se los solicitó para alguna publicación — de ahí que se redacten en tercera persona-, aunque quedaron a medio preparar. Laverde añadió también al final una breve nota con las principales publicaciones a las que el autor no se había referido. Según Egozcue, «la versión autobiográfica nos permite ver a un personaje con hondas raíces en su tierra de Béjar, de temperamento introvertido, proclive a hondos pensamientos, que tras haber pasado en su primera juventud por unos momentos de desvarío religioso y humano, acaba encontrando en los primeros aires que respiró entre los suyos, la atmósfera en que afianzarse» (294), y «...ofrece la fuente de inspiración de Mateos, el pensamiento neocartesiano de Bordas Demoulin, en el que ve la posibilidad de una síntesis entre razón y fe cristiana» (297). Se trata, en efecto, de una autobiografía intelectual: trata de la evolución y progresos de sus ideas, de los autores que fue estudiando y desechando, y de cómo finalmente desarrolló una filosofía católica, moderna y alejada del escolasticismo, basada en Platón y en Descartes, a la que denomina espiritualismo. Ese tránsito de su pensamiento, esbozado apenas en un estilo muy expresivo, nada propio de un resumen autobiográfico impersonal, da el hilo narrativo de estas páginas, aunque también hay una estructura autobiográfica más clásica sobre los hechos principales de su vida, mucho menos desarrollada.

\section{2. [*284]. MAYANS Y SISCAR, GREGORIO}

—Gregorio Mayans y Siscar Digital. Obras completas. Epistolario. Bibliografía. Madrid: Biblioteca Valenciana - Fundación Hernando de Larramendi - Fundación Histórica Tavera («Biblioteca Virtual Menéndez Pelayo de Polígrafos españoles», 2 / «Polígrafos Valencianos», 1), 2002 (1 cederrón). Software de DIGIBIS. 
Se reproduce, junto con el resto de obras y correspondencia de Mayans, la edición y traducción de Antonio Mestre de 1974 de la Maiansii Vita. El cederrón incluye también a texto completo las tesis doctorales, monografías y congresos dedicados al escritor de Oliva en las últimas décadas ${ }^{55}$. Aparte de esta importante novedad bibliográfica, Benavent Montoliu ha aportado otro dato muy significativo acerca de la suerte editorial de la autobiografía encubierta de Mayans, publicada por Juan Cristóbal Strodtmann en Wolfenbttel en 1756, que merece ser añadido a los ya conocidos, pues no lo he visto en ninguna otra fuente: «esta segunda biografía de Mayans [por Strodtmann] aparece nuevamente en la revista Neues Gelehrtes Europa (1758) 8. Th., pp. 849-976» ${ }^{56}$.

\section{3. [*293]. MESONERO ROMANOS, RAMÓN DE}

—Memorias de un setentón. Barcelona: Círculo de Lectores («Biblioteca universal. Maestros modernos hispánicos»), 1997 (441pp.). Prólogo de Manuel Vázquez Montalbán.

Nueva edición de este clásico del género ${ }^{57}$.

\section{MIRASOL, CONDE DE}

Véase: ARÍSTEGUI VÉLEZ, RAFAEL DE

\section{MONEDERO ORDÓÑEZ, DIONISIO}

(N. en Melgar de Fernamental, Burgos, 1842. Combatió como voluntario en la Guerra de África de 1860, por la que fue condecorado. De regreso a Burgos, ejerció como funcionario de hacienda y oficial del Real Patronato del Hospital de Burgos. Autor de numerosos poemas y libros de tema patriótico y nacionalista.)

\footnotetext{
${ }^{55}$ Estas Obras completas también se pueden consultar, desde la primavera de 2003, en línea a través de Internet, dentro de la Biblioteca Valenciana Digital: http://bv2.gva.es. Por otra parte, he dedicado un estudio muy extenso a esta autobiografía en mi citada tesis doctoral.

56 Jorge Fernando Benavent Montoliu. «Los colaboradores de Mayans en sus relaciones con la Ilustración alemana». En Antonio Mestre Sanchís (coord.). Actas del Congreso Internacional sobre Gregorio Mayans. Valencia-Oliva, 6 al 8 de mayo de 1999. Valencia: Publicaciones del Ayuntamiento de Oliva, 1999, 489-525, cita en 509 n.

${ }^{57}$ Véase también: Fernando Durán López. «Las Memorias de un setentón de Mesonero Romanos en el marco de la autobiografía española decimonónica». Anales de literatura española (Universidad de Alicante), 14 (2000-2001), 41-84. Serie monográfica, 4: Memorias y autobiografías, edición de María de los Ángeles Ayala Aracil.
} 
—Episodios militares del ejército de África. Burgos: Imprenta de Sucesor de Arnaiz, 1892 (XIV + 285 pp.).

—Burgos: Imprenta y Librería del Centro Católico, 1893 (XVI + 17-325 pp., + 1 foto del autor). Prólogo de Ángel Stor ${ }^{58}$.

Desde la dedicatoria «A la Sociedad de Veteranos de la Guerra de África» se advierte la propaganda colonialista que informa todo el libro: el gobierno ha de ser consciente del abandono del tratado de Vad-Ras y para ello da a luz «estas pequeñas memorias encaminadas a refrescar la del pueblo español a fin de que os ayude y veáis realizado vuestro deseo, de que sea pronto un hecho consumado el cumplimiento del Tratado con la erección del monumento que os proponéis». El «Prólogo» (IX-XIV) afirma que el conocimiento de la historia heroica de la patria provoca en los lectores, en el pueblo sencillo, emulación y amor al peligro y a la gloria. La colonización del norte de África está en la agenda política europea y desea movilizar la opinión pública en favor de los derechos de España, antes que franceses e ingleses los hagan inútiles. Siguen dieciséis capítulos con sus memorias de la campaña de 1860. El primero es «Entusiasmo del pueblo español»: «...cuando en 1859, el grito mágico de «guerra al moro» resonó por todos los ámbitos de la Península, abandonando los estudios [...], fijé toda mi atención en los hechos que realizaban nuestras tropas en las fragosidades de Sierra Bullones» (5). El cap. II cuenta su embarque en Santander. Desde la llegada a Marruecos se expresa en presente, como si escribiera un diario, aunque sin especificar fechas; no queda claro si es un recurso de estilo o si reelabora un texto preexistente. El centro del relato lo ocupa la batalla de Vad Ras, que narra globalmente y no sólo en su participación. El cap. XVI, ya regresado a España, es una digresión sobre la historia y los méritos de la ciudad de Burgos. Termina criticando la desatención a heridos y veteranos, el caciquismo y la corrupción. Un «Epílogo» (257-276) cuenta su suerte personal tras la guerra, sordo por una herida, condecorado y luego empleado en la hacienda pública ${ }^{59}$; evoca sus relaciones con su admirado jefe en África, José Salcedo, añadiendo un himno poético que le dedicó (266-270); insiste por fin en el

${ }^{58}$ Palau indica de esta segunda edición, que no he visto, que «la fecha del pie de imprenta no es exacta pues los informes emitidos llevan la de 1894». Se localizan ejemplares en varias bibliotecas públicas españolas, como las de Burgos, Cáceres, León, Toledo, Valencia...

59 «En mis treinta y un años de empleado he presenciado cosas tan extrañas para la generalidad de mis lectores, que bien merecían ser publicadas en un segundo libro; mas aunque le tengo escrito con el título de Escenas burocráticas, he suspendido su publicación ahora por causas ajenas a mi voluntad» (260). ...l mismo califica esto de segunda época de su vida, de la que traza ahora un apretado resumen. No tengo noticias de que este otro libro autobiográfico se llegase a publicar o se conserve. 
incumplimiento del tratado por los moros en un nuevo alegato por una política africana agresiva de España. La «Conclusión» (277-278) reitera la decadencia nacional y baja politiquilla que impide a España ocupar su lugar en el Magreb. Un exaltado «Apéndice» (279-285), añadido tras la impresión del resto, da cuenta de nuevos peligros para las pretensiones españolas ${ }^{60}$.

Monedero escribe con un estilo muy retórico, muy decimonónico, con exaltación y desmesura calificativa, reiterando los padecimientos, emociones e impresiones de cada cosa y cada momento, pero sin auténtica penetración moral ni intelectual. Su despreciativa superioridad sobre moros y judíos es verdaderamente colonial. A menudo inserta información más o menos libresca sobre los lugares que transita, y abundan las digresiones sobre el patriotismo y otros asuntos, que cortan las secuencias narrativas. También propende a arranques líricos que denotan la pluma de un poeta (no muy bueno), diálogos, coloristas y largas descripciones, semblanzas de personajes... Este libro, al parecer, fue premiado por el gobierno.

\section{MONEVA Y PUYOL, JUAN}

(N. en Venta de Pollos, Valladolid, 1871, por azar. Zaragozano y de ideas muy religiosas, fue catedrático de derecho canónico en la Universidad de Zaragoza durante muchos años, autor de numerosas obras de tema aragonés, sobre derecho, educación cristiana, gramática, traducciones, etc.)

—Memorias. Zaragoza: s. i., 1952 (534 pp.). Prólogo de J. Valenzuela La Rosa.

Hay una nota inicial: «Han querido los editores conservar en este libro la ortografía personal — tan lógica, tan suya — de Don Juan Moneva y Puyol. Tras madura reflexión se han abstenido de toda nota que pudiera actualizar la obra. La ofrecen así tal y como la escribió Don Juan, tal y como, por su muerte, ha de quedar para siempre: fiel reflejo, hasta en sus minucias, de una personalidad fuerte hasta en sus detalles». El prólogo es

\footnotetext{
${ }^{60}$ Esta muestra bastará para definir las ideas de todo el libro: «Las naciones de Europa deben tener presente que Marruecos pertenece a España; que si un cataclismo de la naturaleza le separó en una de sus terribles manifestaciones creando el estrecho, hoy la ciencia le enlaza de nuevo, y la civilización nos llama allí para acabar cuanto antes con la barbarie que vegeta descaradamente a las mismas puertas de las civilizadas naciones. Noble España; no olvides que en el hermoso suelo que ocupan los fanáticos sectarios del islamismo, se encuentra tu porvenir. Cumple, pues, y lo antes posible, el testamento de la Gran Reina Isabel la Católica» (285).
} 
una sentida y amable evocación de la personalidad del autor. No hay preliminares: el primer capítulo comienza con la filiación de su padre. Son cuarenta extensos capítulos, divididos en epígrafes, que mezclan la materia más personal con capítulos dedicados a biografiar a personajes zaragozanos, o referidos a instituciones y sucesos de la ciudad, enlazadas directa o indirectamente con él. Así se configura una extraña estructura, en que en secuencias más o menos cortas se va pasando de un tema a otro, a veces de modo muy sincopado, dentro de un orden cronológico general, pero con tendencia a la acumulación temática. El primer capítulo trata todo lo relativo a su familia, infancia, matrimonio, etc. En 1878 murió el rector de la Universidad, Jerónimo Borao, y sus padres lo llevaron a ver la capilla ardiente y demás actos; le causó gran impresión y el capítulo II evoca ese episodio. Así va todo, cada capítulo se ocupa de una materia propia o ajena, mejor o peor traída a su historia personal. El conjunto resulta algo disperso y errático, siempre con un estilo ligero.

\section{MONFORT, IGNACIO}

(N. en Manresa, Barcelona, 1798. Carlista, estuvo ligado al servicio del conde de Montemolín en su desembarco en San Carlos de la Rápita.)

—De Franc-Masón a Fraile.

-Los liberales de antaño.

—Diario de la guerra de los Siete Años.

- Memorias de un realista.

-San Carlos de la Rápita.

Tanto estos manuscritos como su autor fueron dados a conocer por un escritor carlista, José Soler y Roig, que firmaba bajo el seudónimo de Carlos Constante, en dos libros titulados Episodios tradicionalistas, concebidos como ardiente propaganda carlista y denigración del liberalismo, quizá evocando el modelo galdosiano ${ }^{61}$. En el primero, se refiere el encuentro casual del autor con un anciano, Monfort, que le relata

61 Episodios tradicionalistas. Montealegre. Narración verídica e histórica de los crímenes y asesinatos cometidos al grito de libertad en Manresa en 1822 y en Montealegre en 1869. Barcelona: La Propaganda Catalana, 1883 (290 pp.). Episodios tradicionalistas. San Carlos de la Rápita (o el conde de Montemolín). Barcelona: La Propaganda Catalana, 1884 (288 pp.). El autor anunciaba un nuevo volumen que se iba a titular Los liberales de antaño. 
varios sangrientos sucesos de las luchas contra los liberales, que le dejaron impresionado y que, como testimonio oral, configuran el contenido del libro. En su lecho de muerte, Monfort le habría entregado los manuscritos citados, que contenían sus otros recuerdos. El último de ellos conforma el segundo Episodio, cuyo afán es reivindicar al conde de Montemolín, mostrar la traición y villanía de los políticos liberales que le traicionaron y sugerir que su muerte fue un envenenamiento. Contiene un extenso relato en forma de extraña paráfrasis, donde a menudo no se sabe quién habla y donde se mezcla la primera persona de Monfort y la tercera persona de Carlos Constante. De vez en cuando, se introduce algún inciso del tipo «continúan diciendo los manuscritos de Ignacio» (38); también se insertan documentos ${ }^{62}$. La materia consiste en la historia de Montemolín; sólo en la p. 72 empieza a contar los hechos que Monfort protagonizó como agente del conde, secuencias puramente novelescas, con abundantes detalles y diálogos, en sobrecargado estilo decimonónico. No he podido confirmar la existencia de este personaje, pero el proceder de Soler y Roig recuerda el recurso ficticio del manuscrito encontrado; si la historia es cierta, estaríamos ante unas memorias político-militares, testimonio de los sucesos del episodio montemolinista filtrado a través de la pluma de un publicista profesional.

\section{7. [*304]. MON[T]SALVATGE Y NOGUÉ, RAMÓN}

(N. en Olot, Gerona, 1815. Capuchino exclaustrado en 1835, combatió al lado de los carlistas hasta el fin de la guerra. Después de la paz de Vergara emigró a Francia, donde en 1841 se hizo protestante y predicó sus ideas entre los emigrados y luego en España. Más tarde pasa a Estados Unidos, tras lo cual se le pierde la pista.)

-The life of Ramon Monsalvatge, a converted Spanish monk, of the order of the Capuchins. With an introduction by Robert Baird. Nueva York: J. F. Trow \& Co., 1845 (170 pp.).

-The life of Ramon Monsalvatge, a converted spanish monk of the order of capuchins. With an introduction, by the Rev. Robert Baird, D. D. Londres: The Religious Tract Society, 1846 (XXXII +112 pp. $)^{63}$.

${ }^{62}$ El extenso capítulo VI es una traducción de un relato francés de un tal Caseneuve, que lo había entregado a Monfort.

${ }^{63}$ Hay un ejemplar de esta rara edición en la colección Usoz (BN, u-5840). 
De este libro Menéndez Pelayo indica que, aunque Usoz lo consideró ficticio, la obra «...está llena de circunstancias tan precisas y algunas tan exactas, que mueven a creer que la novela, si novela es realmente, se bordó sobre un fondo verdadero» ${ }^{64}$. Según la introducción de Baird, se trata de la traducción al inglés de un texto escrito originalmente en francés por Montsalvatge a requerimientos de su grupo religioso evangélico una vez llegó a Estados Unidos: «many persons who heard from his own lips an account of his life, his conversion to true religion, and his subsequents labours in behalf of his countrymen, expressed a desire to see something from his pen, in order that there might be some permanent memorials of the wonderful display of Divine grace which had brought him out of the dreadful darkness and delusions of the papacy into the glorious light of the truth» (V). ...se es el enfoque que preside esta empresa editorial, el de la «evangelización» de la Europa «papista», para lo cual Baird pide el esfuerzo y oraciones de los lectores. Se trata, por tanto, de un clásico relato religioso de conversión con fines proselitistas, al estilo de muchos otros desde el siglo XVI. Consta de doce capítulos y empieza: «In the following pages I shall attempt to give a brief sketch of my history, dwelling especially on the latter years, during which I have had the happiness to be called by our Lord to the knowledge of his truth, and the practice of a Christian life» (1). La conversión se produce en el capítulo IV, en el año 1841: el resto del libro, mucho más circunstanciado, es su experiencia como protestante y como propagandista de su nueva fe, el auténtico centro de interés. Se dirige siempre a extranjeros, por lo que ofrece datos básicos sobre lugares y aspectos de la vida española. También escribe desde la perspectiva que le da su conversión, que le hace reinterpretar con severidad su infancia, su educación y su vida religiosa anterior, dando una siniestra descripción de las penitencias de los capuchinos, que ahora le parecen bárbaras además de supersticiosas. Ese enfoque se coordina a través de una narración lineal, muy coherente en lo ideológico, y directa en cuanto al estilo, que sólo se complica con excursos hímnicos y citas bíblicas.

\footnotetext{
${ }^{64}$ Marcelino Menéndez y Pelayo. Historia de los heterodoxos españoles. Madrid: Editorial Católica (BAC), 1978, vol. 2, lib. VIII, cap. II, 898.
} 


\section{8. [*307]. MORAL VILLALOBOS, JUAN GABRIEL DEL}

—Las memorias de un alpujarreño: Don Juan Gabriel del Moral Villalobos. Entre Fondón y Berja (1796-1826), Valeriano Sánchez Ramos (ed.). Almería: Arráez Editores, 1999 (140pp.). Reproduce también el prólogo de Pedro Aguado Bleye.

Aparece la primera edición en libro de las memorias de Juan Gabriel del Moral (1751-1827), que habían sido publicadas en 1908-1910 por Pedro Aguado Bleye en una revista. Esta reedición se orienta hacia la historia alpujarreña, aunque no por ello deja de ser un buen trabajo, bien documentado. Se reproduce el texto tal como lo publicó Aguado Bleye, porque no se ha localizado el manuscrito original torpemente extractado por aquel historiador. Sánchez Ramos aporta una nueva y valiosa investigación sobre la vida del autor, con rico material de archivos locales, por ejemplo sus testamentos, que proporcionan detalles de su vida familiar y corrigen algunas fechas de las memorias. Incluye índices de lugares y nombres.

\section{NAVIDAD Y PÉREZ, MÁXIMO}

(N. en Madrid 1822. Coronel de infantería, ingresó en el ejército en 1839 y sirvió en las guerras carlistas, de África, Santo Domingo y Cuba, así como en la campaña de México. Sus principales operaciones fueron en Santo Domingo entre 1862-1865 y en Cuba en 1868-1869, de las que sacó condecoraciones y no poca polémica. Desde 1870 está en España.)

\footnotetext{
—Vindicación militar y política del coronel don Máximo Navidad y Pérez. Explicación de su conducta en el tiempo en que como jefe de operaciones tuvo el encargo de pacificar y conservar los cuartones de Brazo de Cauto, Hongolosongo, Solís, Las Dos Palmas y Manacas, hasta el Ramón, en la isla de Cuba. Y reparación que por disposiciones superiores ha obtenido contra las calumniosas suposiciones que se le atribuyeron. Madrid: Imprenta de P. García y Compañía, s. a. [1873] (92 pp. $)^{65}$.
}

${ }^{65}$ Al pie del manifiesto consta la fecha de 29-V-1873. No obstante, el 9-II-1873 ya se había publicado una reseña en el diario progresista madrileño La Iberia, en relación al tema de la esclavitud que se trata incidentalmente en el folleto. 
Comienza este manifiesto con una «Advertencia» (3-4) donde se explica que el autor «se ve en la necesidad, después de haber apurado todos los medios que le daba la ley, de acudir, en demanda de reparación de su honra calumniada, al tribunal de la opinión pública» (3). Ha sido exculpado de todo cargo por sus superiores, pero él cree que eso no es suficiente para hacer lucir la verdad, por lo que se decide a exponer su versión, que además podrá servir de provecho para evitar fracasos en el ejército español de Cuba. El texto se divide en trece secciones numeradas (5-51), formando un seco relato directo, sin preámbulos y ceñido a un único suceso de la carrera militar de Navidad, pero abundando en comentarios inmoderados en propia defensa o alabanza. El nudo de la cuestión reside en una atrevida acción militar de 1869, un desembarco en la ciudad de Aserradero con 200 hombres a los que implicó en una ambiciosa campaña sobre Sierra Maestra que, según él, fue luego calificada de temeraria, pero supuso un éxito militar; le imputaron asimismo tener tratos ilícitos con los insurrectos. Tras contar los detalles de su separación del mando, entra en la dura polémica que le siguió, con las acusaciones recibidas en la prensa, los problemas judiciales, etc. Hay un extenso apéndice de 41 piezas de documentos oficiales (53-92). En suma, unas perfectas memorias justificativas militares.

\section{ORTIZ DE PINEDO, ADELARDO}

(N. 1859. Autor de varias novelas y libros sobre caza.)

—Cuarenta años de cazador. Memorias de caza. Madrid: Biblioteca de Sport de la Casa Jordano y Ca, 1919 (249 pp.).

La Casa Jordano era una armería especializada en caza deportiva. Esta serie de publicaciones supone una apuesta en la promoción de sus actividades empresariales a través de la literatura, a través de una defensa del sport como algo dinámico, propio de los tiempos modernos, inspirado en «la vitalidad industrial y comercial de los Estados Unidos de América, la nación más joven del mundo» (así reza la nota editorial de presentación). El libro consta de nueve extensos capítulos. Empieza con un elogio de la caza como vocación personal a la que hay que prestar esfuerzo y constancia. Inmediatamente el autor se remonta a su primera cacería, con diez años, en 1869 junto 
personalidades como Serrano y Prim. El segundo capítulo se dedica a las escopetas: explica sus experiencias con las que ha venido usando, pero sobre todo hay un desarrollo teórico sobre cómo ha de ser y cómo ha de usarse una escopeta de caza. El resto de capítulos se explayan en bloques temáticos en los que va organizando sus recuerdos y sus reflexiones, buscando siempre ofrecer informaciones útiles para los cazadores: «Cacerías en mano», «Daimiel y Villafranca», «Por tierras de Guadalajara», «Por tierras de Soria», «Los tiradores», «Por tierras de Toledo», «Por Ciudad Real». Hay diálogos y anécdotas, en un intento de dar viveza e interés al estilo. Son las típicas memorias profesionales de estructura anecdótica que proliferan a partir de la segunda mitad del XIX, aunque combinadas en este caso en forma de una guía práctica y manual de cazadores.

\section{OSUNA, DUQUE DE}

Véase: TÉLLEZ-GIRÓN Y ALFONSO-PIMENTEL, FRANCISCO DE BORJA

\section{OTÍVAR, ALCALDE DE}

Véase: FERNÁNDEZ CAÑAS, JUAN

\section{1. [*342]. PARDO BAZÁN, EMILIA}

—Apuntes autobiográficos. En Ana María Freire López. «La primera redacción, autógrafa e inédita, de los Apuntes autobiográficos de Emilia Pardo Bazán». Cuadernos para investigación de la literatura hispánica, 26 (2001), 305-336 (texto en 313-336).

La breve autobiografía de Emilio Pardo Bazán era hasta ahora conocida sólo en su versión como prólogo a Los pazos de Ulloa (1886), pero se ha localizado parte de un manuscrito con una redacción anterior. Los papeles de doña Emilia se conservaron en su pazo coruñés de Meirás hasta 1978, y luego vinieron a ser propiedad de la Real Academia Gallega en La Coruña. Ana María Freire halló en ellos por azar varias cuartillas de los Apuntes autobiográficos, desperdigadas en distintas cajas del archivo. Esta versión constaba en su origen de 84 cuartillas escritas en sentido apaisado (23’1 16’6 cm.) y numeradas; la editora ha podido recuperar 63 (nos 1-22, 24-60 y 81-83), «la gran mayoría en un aceptable estado de conservación, y las restantes no tan deterioradas que hagan imposible transcribir lo manuscrito» (307). «El texto autógrafo [...] es, sin 
duda, anterior al que conocemos impreso, y no se hicieron sobre él las correcciones que dieron como resultado la versión definitiva. Tuvo que existir otra redacción posterior, que sería la que se envió a los editores» (307). Aunque la planta y contenido es muy similar, en la versión de 1886 Pardo Bazán desarrolló algunos párrafos e ideas, cambió el orden de ciertas partes, suprimió o redujo otras secciones. Al análisis de estos cambios dedica Freire la mayor parte de su estudio, concluyendo que la primera redacción es más espontánea y familiar, y que luego se pulió parte de su tono coloquial, haciendo el texto de 1886 más culto y literario. también omitió algunos pasajes que pudieran juzgarse vanidosos o demasiado íntimos, así como juicios de valor sobre escritores y libros, y explicaciones sobre los modelos de algunas de sus novelas, con un indudable propósito de autocensura.

\section{2. [*357]. PÉREZ MACÍAS, DOMINGO}

—[Diario]. En José Agustín Álvarez Rixo. Cuadro histórico de estas Islas Canarias o noticias generales de su estado y acaecimientos más memorables durante los cuatros años de 1808 a 1812. Las Palmas: El Gabinete Literario, 1955 (LX + 335 pp.), apéndice VII, 223-237. Prólogo de Simón Benítez. Epílogo de Francisco de Quintana y León.

—En Agustín Millares Carlo y Manuel Hernández Suárez. Bio-bibliografía de escritores canarios (siglos XVI, XVII y XVIII). Las Palmas: El Museo Canario - CSIC - Cabildo Insular de Gran Canaria, 1975-1992 (6 vols., $2^{\mathrm{a}}$ ed. ampliada del libro original).

Noticia de dos ediciones más de la breve narración de este clérigo canario.

\section{PIFERRER VIÑAS, ISABEL}

(Sant Llorenç de les Arenes, Gerona, 1814- Vilert, Gerona, 1883. Hija de una familia campesina del Bajo Ampurdán, al casarse en 1840 con el hereu de Mas Anglada, pasó a vivir en Vilert como cabeza femenina de la familia. Allí pasó el resto de sus días.)

— [Memorias]. En Albert Compte. «Una vida rural a les terres marginals de l’Empordà, durant la primera meitat del segle XIX». Annals de l'Institut d'Estudis Empordanesos, 26 (1993), 175-232 (texto en 217-227). 
En el archivo familiar Anglada de Vilert hay un fondo de documentación y escritos de diversos miembros del linaje, dentro de la fértil tradición catalana de los libros de familia. Uno de ellos es una evocación autobiográfica de Isabel Piferrer, que Xavier Torres califica de «insòlites memòries» (30). El manuscrito consta de un cuaderno con 28 páginas tamaño cuartilla, escrito a los 67 años, en una extraña mezcolanza de castellano y catalán, fruto del intento, a duras penas conseguido, de redactarlo en castellano. Igualmente se entrecruzan la primera y la tercera persona. Empieza: «En el dia 10 de desembre del añ 1814 bingué al mon Isabel Piferrer del poble de San Llorens de las Arenas. En el dia que cumplió un añ la Madre se fue a casamiento de una ermana mía y fora mama, al cap de poch me poso mala y estuvo 15 dias al barasol, sempre dien: mam, mam, y la Madre me daba aygua fresca y nada mas, porqué nada podia pasar; por eso no murió, pero muy flaca siempre. Cuando tubo tres años y un mes, se casó otra ermana. O cielos! cuando yo la beig que ba tan bonica y comenso a desir: ella ray que es casada!» (217-218). Así evoca, con muchos diálogos, unos pocos episodios de gran candor y sencillez, siempre desde el punto de vista de la memoria subjetiva, sin elaborar un discurso complejo. Una burla de muy niña, sus sucesos como pastora con los lobos a los doce años, cómo accede a aprender a escribir cuando recibe carta de un joven pretendiente, ataques de los ladrones, las enfermedades que padeció, las circunstancias de noviazgos y boda, su nueva vida de casada, pequeñas añoranzas íntimas... Termina haciendo balance de los pocos que quedan vivos de su familia directa, para concluir entre medrosa y resignada que «los 3 estamos solos, esperando de oy a mañana la ditxosa Muerte» (227). El último párrafo es la enumeración y datos de sus padres y hermanos.

Bibliogr.: Xavier TORRES SANS. Els llibres de família de pagés (segles XVIXVIII). Memòries de pagés, memòries de mas. Gerona: CCG Edicions - Associació d'història rural de les comarques gironines - Institut de Llengua i Cultura Catalanes de la Universitat de Girona, 2000, 30-31, 120.

\section{4. [*371]. POZO Y CÁCERES, JUAN LUCAS DEL}

(Córdoba 1798 - después de 1863. Estudió en el cordobés colegio del Ángel para Infantes de Coro desde 1806, luego fue acólito de la catedral y músico de la misma entre 1823-1842. Sus últimos años los pasó sordo y pobre. También fue un erudito en 
historia local cordobesa, aunque nunca publicó sus trabajos. Mantuvo, según dice, «correspondencias familiares» con Estébanez Calderón, Gayangos y Hartzenbusch.)

—Apuntes para mi vida. En Fernando Durán López. «Los Apuntes para mi vida de Juan Lucas del Pozo: una breve autobiografía inédita en la Córdoba del XIX». Cuadernos de Ilustración y Romanticismo, 10 (2002), 223-235.

En mi Catálogo reproduje la breve e inexacta noticia que da sobre este opúsculo Rafael Ramírez de Arellano ${ }^{66}$, que ahora enmiendo y desarrollo a la vista del documento original que he editado por primera vez en el artículo citado. Forma parte de un volumen facticio y manuscrito de obras de Juan Lucas del Pozo (la práctica totalidad de las que se le conocen), signatura ms. 67 de la Biblioteca Pública Provincial de Córdoba, que contiene cuatro cuadernos en $4^{\circ}$ encuadernados juntos, de fecha diversa, con escritos del autor originales o copiados de libros (un total de 431 pp. paginadas correlativamente e indizadas por Francisco de Borja Pavón). Los Apuntes están en el cuaderno $3^{\circ}$, pp. 221-232 del volumen (son, pues, más de las cuatro páginas de que habla Ramírez de Arellano). Constan de varios textos adicionados entre septiembre y octubre de 1863, con notas y llamadas que remiten unos a otros, en la típica estructura confusa y acumulativa de las autobiografías privadas manuscritas. Respecto a su escaso contenido, sigue valiendo la descripción de Ramírez de Arellano: «Trae muchas lamentaciones por su mala suerte y quejas bien fundadas del Cabildo eclesiástico. También trae noticias curiosas de la entrada en Córdoba de los franceses y de la huida del obispo Sr. Trevilla». Se ocupa tan sólo de algunos grandes incidentes de su vida, en particular de su relación con la música, el colegio del Ángel, el cabildo catedralicio cordobés y sus canónigos, temas todos ellos entrelazados en una misma peripecia biográfica y presididos por idéntico tono sombrío y rencoroso ante el maltrato que siente haber padecido. A esto se suman detalles de tipo más testimonial sobre la Guerra de la Independencia y otros hechos político-militares de la ciudad y su Catedral. Parte está escrita en tercera persona y parte en primera.

${ }^{66}$ Ensayo de un catálogo biográfico de escritores de la provincia y diócesis de Córdoba, con descripción de sus obras. Madrid: Tipografía de la Revista de Archivos, Bibliotecas y Museos, 19221923, t. I, n ${ }^{\circ} 1550$. 


\section{PUENTE, JOSÉ MARÍA}

(Político y magistrado. Tras años de servicio de toga, combatió en el ejército patriota en la Guerra de la Independencia; fue jefe político de Cuenca en 1820, y luego de La Coruña entre 1820-1821. Liberal exaltado.)

—Manifiesto que hace a la nación don José María Puente, jefe superior político que fue en la provincia de Galicia, con motivo de su exoneración del mando por las prisiones que decretó en 30 de mayo de este año de varias personas indicadas de conspiración. Madrid: Imprenta del Imparcial, por su regente don José Gallego, 1821 (87 pp.).

Durante un periodo de gran agitación política, la primavera de 1821, hubo detenciones de numerosos absolutistas en La Coruña; Puente, con las otras autoridades, deportó a Canarias a 42 detenidos, en su mayor parte religiosos. El gobierno le cesó y es entonces cuando publica su manifiesto (3-14) junto con ocho «Documentos justificativos que acompañan a este manifiesto» (15-87). El comienzo desarrolla los habituales tópicos del género autoapologético: «el ex jefe político de Galicia va a exponer al público su conducta con aquella franqueza y buena fe que le caracterizan. El gobierno, las Cortes y la nación serán los jueces; a todos se somete, para que por los hechos y documentos que va a presentar decidan quién es el reo en esta importante causa, en que se halla altamente comprometida la grande de la libertad de la patria» (3). Explica que fue nombrado para afianzar en Galicia el régimen constitucional, pero se encontró con una fuerte oposición. ...l era partidario de usar su mando con firmeza contra los refractarios, pero nunca se vio respaldado por el gobierno, que daba alarmantes muestras de debilidad. Es, en suma, la visión política del liberalismo exaltado del momento, que cree perdida la causa constitucional si no se ejerce más autoridad. El relato, no muy ordenado y más apologético que narrativo, cuenta todas las incidencias de sus meses de mandato, justifica sus acciones y reivindica su honor dañado ${ }^{67}$.

\footnotetext{
${ }^{67}$ Hubo réplica por parte de uno de los deportados, negando los cargos de conspirador y acusándole de crueldad: Santiago Pastoriza Taboada y Martínez. Contestación al Manifiesto que dio a la Nación Don José María Puente, ex Jefe político Superior de Galicia. Santiago: Imp. de Juan Francisco Montero, 1822 (73 pp.). También: Francisco Javier de Estanga, Rufino Antonio de Alegría, Pedro de Velarde,.Observaciones al Manifiesto de D. José María Puente, ex jefe político de Galicia por lo que contiene de injurioso al cabildo de S. A. M. I. de Santiago. Santiago: Imprenta de D. Juan Bautista Moldes, 1822 (42 pp.).
} 


\section{RENDÓN, JOSÉ MARÍA}

(Ronda, Málaga, 1791 - Madrid 1855. Militar. Combatió en la Guerra de la Independencia y en la primera guerra carlista, a las órdenes de Luis Fernández de Córdova.)

—Única herencia de los hijos del General Rendón.

Según José María Azcona, Rendón «en 1835, brigadier agregado al cuartel general de don Luis Fernández de Córdova, a cuyas órdenes militó en la campaña contra Zumalacárregui. Escribió sus memorias, que utilizó Chamorro para trazar su biografía ${ }^{68}$. Estas memorias las entregó a su esposa antes de morir y las tituló Única herencia de los hijos del General Rendón. No dice Chamorro dónde se hallan» (Zumalacárregui. Estudio crítico de las fuentes históricas de su tiempo. Madrid: Instituto de Estudios Políticos, 1946, 545).

\section{7. [*403]. ROJAS CLEMENTE, SIMÓN DE}

—[Autobiografía]. Publicada como «Necrología». Gaceta de Madrid, 37 (27-III-1827), 146-148.

Con anterioridad a la edición en varias entregas del Diario de Avisos de Madrid a partir del 28-III-1827, el texto necrológico extractado de una autobiografía inédita del botánico Rojas Clemente se había publicado en el otro y más importante periódico oficial de la Corte, sin que se registrase ningún cambio respecto de la edición de la que informé en mi catálogo ${ }^{69}$.

\section{ROJAS Y CONTRERAS, JOSÉ DE}

(N. en Valladolid, 1701. Primer marqués de Alventos. Miembro de una encumbrada familia antequerana, pasó con cuatro años a Madrid. Estudió en la Universidad de

\footnotetext{
${ }^{68}$ Se refiere a la incluida en el Estado mayor del ejército español. Madrid: Impr. de Tomás Fortanet, 1851 (4 vols.), de Pedro Chamorro Baquerizo.

69 Véase Samuel Rubio Herrero. Biografía del sabio naturalista y orientalista valenciano Don Simón de Rojas Clemente Rubio (1777-1827). Madrid: Edición del autor, 1991 (344 pp.). Este texto es otro de los que estudio ampliamente en la segunda parte de mi citada tesis doctoral.
} 
Salamanca, en cuyo Colegio de San Bartolomé entró en 1719. Tuvo una larga carrera como magistrado en Santiago, Sevilla, Zaragoza, Jerez, Madrid..., y está en el Consejo de Indias desde 1752.)

-[Autobiografía en tercera persona]. En Historia del colegio viejo de San Bartolomé, mayor de la célebre Universidad de Salamanca. Segunda parte. Tomo primero, que contiene las vidas de los cinco eminentísimos y excelentísimos fundadores de los insignes colegios mayores de Santa Cruz de Valladolid, de Santiago el Zebedeo (llamado vulgarmente de Cuenca), de San Salvador de Oviedo, del nombrado del Arzobispo en la Universidad de Salamanca, y del de San Ildefonso de Alcalá; y un catálogo de los excelentes varones que han vestido sus becas. A que siguen las entradas de los que desde el año de 1640 hasta el de 1768 han sido elegidos en el mayor de San Bartolomé. Escrita por don José de Rojas y Contreras, marqués de Alventos, caballero del orden de Calatrava, venticuatro de Sevilla, colegial del dicho colegio, del consejo y cámara de Indias y de la junta general de tabaco. Madrid, Andrés Ortega, 1768, 694-709.

Es el segundo de tres volúmenes en que Rojas reedita y amplía una obra de 1661 de Francisco Ruiz de Vergara, consagrada a alabar a la casta colegial salmantina, y en particular al Colegio de San Bartolomé. Fue esta institución la que en 1761 encargó a Rojas esta labor, dentro de la campaña defensiva de los colegiales contra las reformas universitarias promovidas por los manteístas. En su estrategia de ensalzar la nobleza, lustre e importancia de los linajes colegiales, el autor incluye su propio currículo uitae, del que pueden leerse fragmentos representativos en el artículo de Carabias. El primer párrafo es una prolija enumeración de títulos y dignidades propios y familiares, en el estilo formulístico que preside toda la nota. El siguiente empieza: «Fue recibido por colegial en 21 de junio de 1719, siendo caballero del orden de Calatrava. En el año de 1722 se graduó de licenciado en leyes...» (695). Hasta la p. 699 expresa las etapas, cargos, consultas y comisiones que formaron su carrera pública, con breves noticias y comentarios elogiosos sobre sus resultados y sobre el honor que le reportaban. Al llegar a su título de marqués, cumbre de su ascensión, inserta una digresión biográfica sobre su benefactor, el Infante Felipe, duque de Parma, y cambia a primera persona, en plural de modestia. En la p. 703 retorna al hilo perdido de sus distinciones, su casamiento (con la consabida retahíla de honores de su familia política), los nombres y suerte de sus hijos, siempre remarcando la vinculación con el Colegio de San Bartolomé. Según Carabias, «esta autobiografía [...] nos coloca ante una paradigmática apología del linaje nobiliar endogámico; una de las características definitorias de la casta colegial, tanto en 
su vida social como en la laboral» (550). En efecto, el orgullo social, la legitimación nobiliaria por la vía genealógica, el formulismo y la reducción de la propia imagen a un concepto ceremonial y público de la autoestima, son los rasgos sobresalientes de esta pobre nota, falta de todo interés.

Bibliogr.: Ana María CARABIAS TORRES. «La polémica entre resistencia y cambio cultural en España: el ejemplo de don Joseph de Roxas y Contreras». En El mundo hispánico en el siglo de las luces. Madrid: Editorial Complutense - Sociedad Española de Estudios del Siglo XVIII, 1996, I, 541-555.

\section{ROMANONES, CONDE DE}

Véase: FIGUEROA Y TORRES, ÁLVARO DE

\section{9. [*404]. ROMERO, PEDRO}

-Autobiografía [eso dice la portada interior y la cubierta, pero en la sobrecubierta reza Autobiografía, cartas y escritos], Luis Carmena Millán (ed.). Ediciones de la Idea, José Esteban, editor («Las Páginas del Tendido», 2), 1988 (45 pp.). Ilustraciones de Javier Martín.

Referencia de otra edición, que incluye el mismo texto editado en 1904 por Editorial Lux, sin que se le añada ni siquiera una nota sobre su procedencia.

\section{SALVADOR SALLIURA, LLUÍS M.}

(Fines del XIX y principios del XX. Hacendado rural de Romanyà de la Selva, en Gerona.)

—Trigo del país. Notas escritas per a la meva família, a fi que d'ellas en treguin un recort, una instrucció y una experiéncia, ms. escrito h. 1930, conservado en el Archivo Histórico de Gerona, Fondo Salvador.

Según Xavier Torres, fue uno de los numerosos campesinos catalanes que, en el marco de una sólida tradición familiar, dejó textos escritos para testimonio de su linaje. En el mismo fondo archivístico de su familia se conservan varias libretas y biografías familiares redactadas por él en castellano y en catalán. Torres da las siguientes 
referencias: Breve noticia de la vida de mi querido padre D. José Salvador y Giribert (h. 1888) y Breu notícia de la vida de ma inolvidable mare $D^{a}$ Francisca Salliura y Cuffí (sin fecha), además de un libro «clásico» — dice— de nacimientos y defunciones entre 1851-1910. Aunque no especifica el contenido exacto de Trigo del país, sí indica que constituye un buen ejemplo de la transición entre los libros de familia tradicionales y los géneros autobiográficos más modernos y elaborados.

Bibliogr.: Xavier TORRES SANS. Els llibres de família de pagés (segles XVIXVIII). Memòries de pagés, memòries de mas. Gerona: CCG Edicions - Associació d'història rural de les comarques gironines - Institut de Llengua i Cultura Catalanes de la Universitat de Girona, 2000, 30-31 y apéndice.

\section{SANTA GADEA, CONDE DE}

Véase: GONZÁLEZ TORRES DE NAVARRA, LUIS

\section{SARACÍBAR, S. JULIO DE}

(N. en 1872. Abogado, fue candidato de Canalejas al Congreso sin éxito y se empleó en diversos cargos menores, además de ser funcionario del Senado desde 1897. Con Primo estuvo en las cercanías de la Unión Patriótica. Publicó varios libros sobre el Senado, contra el catalanismo y sobre cuestiones jurídicas y políticas.)

—Del Senado que desapareció. Memorias de un funcionario senatorial, ya casi sesentón (18971931). Madrid: Imprenta Julio Cosano, 1932 (226 pp.).

Es una edición de lujo, con buen papel, numerosas fotografías, caja de imprenta orlada y cuerpo de letra grande y espaciado. Este libro tiene que ver con la desaparición del Senado en la constitución republicana: Saracíbar no oculta su lealtad monárquica y habla con gran desapego de los nuevos tiempos. La obra se dedica a su amigo el Barón de Viver, alcalde de Barcelona durante la Dictadura, y consta de doce capítulos y un apéndice con papeles históricos referidos a las Cortes de la Restauración. Son unas memorias profesionales, en muy escasa medida autobiográficas: el centro de interés es la institución, el Senado, y el texto se configura como un centón de anécdotas, escritas en estilo evocador y jocoso, que mezclan sucesos personales en el trabajo y asuntos 
curiosos ocurridos en la cámara alta. Hay numerosas semblanzas de personajes, una tendencia vaga a la asociación temática y, ante todo, un deseo de agradar con un tono ocurrente, que nunca cobra mucho vuelo. El último capítulo rompe la continuidad establecida: es una valoración personal de su vida, que él llama confesión general a sus hijos, y consiste en una defensa de su trayectoria y un análisis de su carácter y valores humanos en que, con poco de autocrítica pero sin caer en el halago burdo, expone su visión del mundo, sobre todo en política. Uno de sus móviles es marcar diferencias con la Dictadura, a la que muchos lo sentían vinculado. Empieza así: «Es muy difícil, casi imposible, cuando se redactan unas Memorias como las presentes, que quien las escribe, al relatar todo aquello que ha visto o en que ha intervenido [...], no haga a ratos su autobiografía, aun sin quererlo. Sabía yo de antemano que corría este riesgo, y no quise, sin embargo y desde un principio, trazarme, rehuyéndolo, una línea divisoria entre uno y otro campo, para no pasar de ella, seguro como estaba de que tendría forzosamente que atravesarla con frecuencia» (173-174).

\section{2. [*418]. SARMIENTO, MARTÍN}

—_Autobiografía]. En José Luis Pensado (ed.). Estudos adicados a Fr. Martín Sarmiento. Artigos tirados dos «Cuadernos de Estudios Gallegos» (1945-1982). Santiago: Instituto de Estudios Gallegos «Padre Sarmiento», CSIC, 1995 (545 pp.), 349-363.

Se trata de la misma edición de Vida y viajes literarios de Fray Martín Sarmiento que había sido ya publicada en Cuadernos de Estudios Gallegos. Aprovecho esta adición para considerar otro importante aspecto de esta obra. Tanto en el prólogo del libro citado de 1995 (XVIIIXIX), como en un trabajo de $1972^{70}$, José Luis Pensado ha expuesto su convicción de que esta autobiografía es apócrifa. Según él, en 1767 Sarmiento elaboró un Catálogo de sus obras, armazón esquemático y bibliográfico para una vida literaria, pero sin desarrollo, que se conserva autógrafo (BN, ms. 17642). Posteriormente, Fr. José Goyanes realizó una nueva copia con añadidos, que figuraba en un manuscrito de la Biblioteca Provincial de Orense, destruido en un incendio de 1927; antes de la quema se había publicado como Vida y viajes literarios, y es ésa la versión

\footnotetext{
${ }^{70}$ José Luis Pensado. Fr. Martín Sarmiento, testigo de su siglo. Discurso pronunciado en la solemne apertura del Curso Académico 1972-1973. Salamanca: Universidad de Salamanca, 1972, 15-17. Me ocupo de esta cuestión en mi citada tesis doctoral de 2001.
} 
que se ha reproducido varias veces. Pensado cree que la versión publicada no es, pues, una versión ampliada por Sarmiento de su Catálogo de 1767, sino una pseudoautobiografía preparada torpemente por Goyanes, entresacando pasajes de otros escritos y con numerosos errores. Su argumentación es sólida, pero ya no existe el manuscrito que permitiría contrastarla: los errores pueden deberse a malas transcripciones, así que la cuestión queda abierta.

\section{3. [*432]. SOMOZA Y MU-OZ, JOS...}

-[Artículos autobiográficos]. En El risco de la Pesqueruela y otras prosas, José Luis Puerto (ed.). Valladolid: Castilla Ediciones, 2002 (144 pp.).

En esta nueva edición recopilatoria de 27 artículos de Somoza, según la edición y clasificación de la de Lomba y Pedraja, incluye, entre otros, «Noticia autobiográfica» (21-24) y «Una mirada en redondo a los sesenta y dos años» (27-34).

\section{SOR, FERNANDO}

(Barcelona 1778 - París 1839. Guitarrista y compositor. Hacia 1789-1790 estudió en Montserrat, luego entró en el ejército. Hasta 1808 alterna trabajos musicales y militares. En la guerra compuso canciones patrióticas, pero en 1810 se afrancesó. Vive en París entre 1813-1815, en Londres entre 1815-1823, viaja luego a Rusia y pasa de nuevo en París los últimos doce años de su vida.)

—[Resumen autobiográfico]. En A. Ledhuy y H. Bertini. Encyclopédie Pittoresque de la Musique. París: 1835.

—En Brian Jeffery. Fernando Sor. Composer and guitarist. Londres: Tecla Editions, 1979 (197 pp.), 117-130. Es la 2a ed. corregida; la primera de 1977.

En la Encyclopédie Pittoresque, Sor había firmado algún artículo y, según Jeffery, también hay que atribuirle el de su nombre, que figura en varios fascículos (nos 40-43), con paginación variada, a dos columnas, seguido luego de partituras, dibujos, etc. ${ }^{71}$

${ }^{71}$ En ese texto se da su nacimiento en 1780, cuando Jeffery ha documentado que fue en 1778 . Un error así estropearía la atribución, de modo que lo explica así: «the reasons for the mis-statement remain 
Cerca de la mitad del artículo lo ocupan sus recuerdos de Montserrat, escritos en primera persona y entrecomillados; «the rest is written in the third person, but in such precise detail that it was surely Sor who wrote it» (108). Jeffery publica en facsímil el artículo completo de la enciclopedia. Se escribe, por supuesto, en francés y en tercera persona excepto una larga secuencia entrecomillada, que se presenta así: «Quelques détails sur le célèbre couvent du Montserrat ne peuvent manquer d’intéresser nos lecteurs. Nous les empruntons textuellement aux Mémoires de Sor» (118). Se centra muy principalmente en la formación y carrera musical de Sor, ocupándose también de los hechos esenciales de su vida, pero sin profundizar en ninguno; la música es el centro y objeto de esta rememoración profesional. Obviamente los datos los ha proporcionado él, incluso si no lo hubiera escrito; en alguna ocasión hasta se coloca una palabra en castellano entre paréntesis para especificar algún término francés, como se hace en una traducción. Da la impresión de que Sor preparó un texto a requerimiento de Ledhuy, pero que éste se limitó a resumirlo, y dejó sólo literal la parte de Montserrat porque tanto desarrollo no hubiera tenido lógica en una biografía de enciclopedia más que como testimonio personal. Pero es difícil precisar más que estas conjeturas.

\section{5. [*437]. TÉLLEZ-GIRÓN Y ALFONSO-PIMENTEL, FRANCISCO DE BORJA}

(1785-1820. Duque de Osuna, entre otros muchos títulos. Fue declarado traidor por José Bonaparte, sus bienes confiscados y él preso en Francia, de donde logró huir en 1808.)

—Evasión del duque de Osuna de Francia, escrita por él entonces a su llegada a España, para satisfacer la curiosidad de sus hermanos y amigos, publícala su agradecido amigo A. Cádiz: Imprenta de Niel hijo, 1812 (37 pp.).

-Su evasión de Francia, escrita por él a su llegada a España. La publica su amigo A. Cádiz: Imprenta de Requena, 1812 (28 pp.).

obscure, but may have had something to do with claiming a war pension in Paris in the latter part of his life, or something of this nature» (11). 
—Evasión del duque de Osuna de Francia, escrita por él entonces a su llegada a España, para satisfacer la curiosidad de sus hermanos y amigos, publícala su agradecido amigo A. Cádiz: Reimpreso en la Imprenta de D. Manuel Carreño, 1812 (28 pp. $)^{72}$.

Esta última edición se abre con una «Carta que el autor de este viaje me escribió insistiendo yo en que me permitiera imprimirlo» (3-4, firmada en Cádiz, 3-I-1812). En tono familiar, F. G. (Francisco Girón) le dice a su amigo que «ese malísimo papelucho que escribí, al llegar a España, por complacer a una hermana» (3) no tiene interés real para publicarse, pero cede a su insistencia. No cree haber hecho nada que no hicieran otros muchos y si se ponen a publicar sus relatos inundarán las prensas. Sigue la «Relación de mi viaje a España desde Cauterets hasta Sallent, pueblo fronterizo de Aragón con Francia, dirigida a mi hermana la marquesa de Santa Cruz» (5-28). Empieza así: «Hallábame, como sabes, Joaquina mía, en las aguas de Cauterets menos por necesidad de ellas que por ser éste el único medio que encontré para libertarme de firma, jura y acompañamiento del rey cómico; era mi proyecto no salir de allí hasta saber con seguridad su llegada a Madrid y sabida marcharme a España, llegar a Irún y desde allí dirigirme al ejército más cercano» (5). A partir de aquí relata su viaje, una vez le negaron el pasaporte, para cruzar la frontera en circunstancias de pura aventura, detenciones, fugas... Se narra con vivacidad, diálogos y mucho detalle menudo, sin propósito justificativo ni testimonial, simplemente por el valor que pueda tener la anécdota en sí misma. La apelación a la interlocutora, Joaquina, aparece aquí y allá en el característico tono familiar que hace al caso. Termina cuando se reintegra al ejército español: «...sta es la relación de cuanto he sufrido en mi penoso viaje, la misma que te dedico por el amor que me tienes, y por el interés tan vivo que siempre has tomado por todo lo que tiene conexión con tu amante hermano. Madrid 27 de setiembre de 1808» (28).

Bibliogr.: Jean-René AYMES. Los españoles en Francia 1808-1814. La deportación bajo el Primer Imperio. Madrid: Siglo XXI, 1987, 51-53.

72 Este folleto ofrece unos datos bibliográficos muy confusos, porque se transmiten en las fuentes errores en los nombres de las imprentas, las fechas y los propios autores (se atribuye a menudo a un duque de Osuna distinto, Pedro Téllez-Girón Beaufort); además es bastante raro en bibliotecas y a menudo se cruzan unas referencias con otras. En la del Palacio Real se conserva un ejemplar (sg. III/6589, varios impresos 127-11) de la edición de la Imprenta de Niel hijo (que Palau y Aymes equivocan en Imprenta Daniel hijo, error que transmití en mi Catálogo), y otro de la reimpresión de Carreño (sg. III/6598,varios impresos 136-13), que es el que he visto directamente; en ambas fichas de su catálogo se contienen errores. La edición de Requena sólo la he visto citada en el Diccionario bibliográfico de la Guerra de la Independencia Española... Madrid, 1944-1952 (3 vols.). 


\section{TORATA, CONDE DE}

Véase: VALDÉS Y SIERRA, JERÓNIMO

\section{VALDÉS, DIONISIO}

(Diputado por Madrid en 1822-1823, y asociado a los comuneros, firmó varios manifiestos políticos antirrevolucionarios. Más adelante tuvo una controvertida actuación como jefe político de Barcelona en 1841.)

—Manifiesto que en vindicación de su conducta hace a la nación D. Dionisio Valdés, jefe político que fue de Barcelona, sobre los acontecimientos que tuvieron lugar en la misma desde la instalación de la Junta de vigilancia (10 de octubre) hasta el día 15 de noviembre. Barcelona: Imprenta del Constitucional, 1841 (64 pp.).

En la presentación (3-6) Valdés se reconoce como uno de los protagonistas de los graves sucesos de octubre y noviembre del 41 en Barcelona y que por ello se le reprochaba debilidad ante la rebelión o incluso deslealtad al gobierno. «Necesito vindicarme tan completa y tan claramente como mi honor y reputación, que han permanecido intachables durante tantos años de vida pública lo exigen y requieren imperiosamente. Si no estuviese seguro de conseguirlo, me ocultaría de la vista de mis compatriotas» (4). Dice que su relato será breve y sencillo, sin detalles que cansen y sin la acrimonia que estaría justificada, porque no es hombre de guardar odio ni rencor. El cuerpo del texto (7-55) se fecha en Barcelona, 9-XII-1841. Es un relato corrido de todas las incidencias del gobierno de la ciudad y de la conspiración gestada en ella. La narración, ayuna de comentarios, termina en la p. 37; tras un espacio en blanco, escribe: «No he creído conveniente interpelar en la relación sencilla que acabo de hacer [...] reflexión alguna por no distraer la atención de los lectores e impedirles el formar una idea exacta de ellos» (37). El resto es un juicio general sobre el desarrollo y las consecuencias del episodio, en una apología ya explícita. Sigue un «Apéndice» (57-64) con nueve documentos acreditativos. Es una muy convencional memoria justificativa.

\section{VALDÉS SIERRA, JERÓNIMO}

(Villarín, Asturias, 1784-Oviedo, 1855. Conde de Villarín, conde de Torata. Militar 
que tomó parte en la Guerra de la Independencia; en las campañas del Perú fue uno de los sublevados contra el virrey Pezuela y de los derrotados en Ayacucho. Teniente general en 1833. Tuvo gran papel en la primera guerra carlista, como virrey de Navarra. Luego fue capitán general de Cuba.)

—Biografía del Excmo. Sr. D. Jerónimo Valdés, conde de Villarín, teniente general de los ejércitos nacionales. Escrita bajo la dirección de don Manuel Ovilo y Otero, y publicada en la Historia de las Cortes de España y Biografías de los Diputados y Senadores. Madrid: Imprenta de D. B. González, 1850 (366 pp.).

Manuel Ovilo y Otero pedía a muchos de sus biografiados que le remitieran ellos mismos sus biografías ${ }^{73}$. Esta extensa y documentada vida en tercera persona delata por todos sus costados la autoría autobiográfica original; es tan minucioso y está escrito de manera tan cercana que resulta difícil dudarlo. Lo que no sabemos es cuál y cuánta fue la participación de Ovilo que, significativamente, se presenta como «director» y firma algunas notas al texto como «nota del editor». Comienza sin preámbulos con el nacimiento. El breve primer capítulo se ocupa de sus primeros años y juventud, estudios y travesuras antes de tomar carrera. El cap. II (7-43) entra en los sucesos de la Guerra de la Independencia. El cap. III trata de las «Campañas del Perú» (43-152) con el relato de las luchas que concluyeron en la derrota de Ayacucho; se usan y discuten aquí otras fuentes escritas sobre los acontecimientos. El cap. IV versa «Desde la batalla de Ayacucho hasta la muerte del Rey acaecida en 1833» (153-163); el cap. V «Desde la muerte del Rey hasta concluir la primera campaña en las provincias del Norte» (163344). En ese punto se coloca una pequeña raya que parece indicar el cambio de capítulo, aunque lo que sigue, que se ocupa de la siguiente etapa de la carrera militar de Valdés como gobernador y capitán general de Cuba, no se introduce con ningún epígrafe; termina esa última sección en la p. 358. Finaliza con una «Conclusión» (359-366), en que se justifica la necesidad de hablar tanto y tan calurosamente de un personaje vivo que aún espera rendir servicios a la nación; recapitula las principales piezas de su biografía, en particular las que han sido peor entendidas por la opinión pública o por la malquerencia. En conjunto, y quitando el primer capítulo de tono personal, constituye

${ }^{73}$ Cita concretamente este caso J. P., el anónimo editor de la autobiografía del deán Cepero: «Lo denuncia también lo pormenorizado y exacto de algunas biografías; lo que se escribe del general don Jerónimo Valdés, sólo éste podía saberlo; y no hay duda de que él es el autor del texto» («Del Deán López Cepero: apunte autógrafo y autobiográfico». BRAH, t. 171, cuad. III, 1974, 460). 
unas prolijas memorias militares, que siguen muy de cerca y con infinidad de pormenores los acontecimientos de la carrera de Valdés, contados de la forma más favorable para su imagen y gloria personal ${ }^{74}$.

\section{VALLE JIMÉNEZ, ¿MARGARITA? DEL}

(Fuentes de Año, Ávila 1865 - Talavera de la Reina, Toledo, 1941. En religión Margarita del Espíritu Santo. Era hija de Gregorio del Valle y de Isabel Jiménez, maestros rurales. Profesó con las carmelitas descalzas de Talavera en 1892 y allí estuvo el resto de su vida.)

_[Escritos autobiográficos espirituales]. En Fray Matías de Jesús. Dios al descubierto. Su percepción en el vivir de un Carmelo. Madrid: Bibliográfica y Santiago Rodríguez S. A., 1972 (174 pp.).

Este volumen contiene escritos espirituales y autobiográficos de esta religiosa, preparados por el fraile que firma el trabajo, en la tradición de autobiografías por obediencia mantenida desde el Siglo de Oro. La monja los dirigió a sucesivos confesores, en especial al P. Narciso de San José, bajo cuyas órdenes redactó abundantes experiencias místicas. El editor tiene noticias de hasta siete cuadernos entregados antes de 1924 y hoy perdidos; se conservan dos de 1909-1912 y 1924-1927 y tres posteriores que no llegó a poner en manos del P. Narciso, además de cartas y cuentas breves de conciencia. En 1931 y en 1936, con las agresiones anticlericales, dice haber quemado casi todos los otros escritos que guardaba. Fray Matías se hizo cargo de los papeles del P. Narciso a su muerte en 1950 y los reunió con los del convento de Talavera. En 1972 dice recoger «solamente el cuaderno entregado [...] en 1927, porque es el que estaba en mi carpeta y que es además el más completo y como resumen de lo más destacado de toda su vida anterior» (15).

El libro comienza con un resumen de la vida de la hermana por su priora. Sigue una sección que el editor titula «Escritos autobiográficos», discontinua autobiografía

\footnotetext{
${ }^{74}$ Jerónimo Valdés ofrece el típico perfil del militar obsesionado por justificar sus actos y hacerlos valer ante la opinión pública: ya en 1813 presentó y publicó una representación a las Cortes, junto con otros siete oficiales; en 1824 un extracto de un diario de operaciones en Perú; en 1839 observaciones sobre ciertos discursos parlamentarios; lo que más desvelos le causó fue su conducta peruana: escribió una extensa refutación al Manifiesto de Joaquín de la Pezuela (véase la entrada no 361 de mi Catálogo de 1997).
} 
espiritual encabezada con la frase (no se sabe si es del editor) «Escribe por obediencia» y fechada en 8-IX-1923. Los capítulos sucesivos parecen corresponder en su mayor parte a una relación de favores divinos al estilo aurisecular; otras veces adopta una disposición cercana al diario espiritual. El cap. V, «La llamada de Dios», es más autobiográfico, al relatar la llegada de su vocación; luego habla de su noviciado, de su profesión; vuelve más tarde a la relación de favores. Algunos de los textos finales son posteriores a la fecha indicada, ya que se refieren a tiempos de la República. Hay también secciones de contenido doctrinal, en que estudia la oración, las gracias, etc. El conjunto es deslavazado, parecen textos escritos en situaciones diferentes, aunque con homogeneidad de estilo y enfoque espiritual. La hermana Margarita escribe en un registro correcto, pero bastante pobre. «Su escritura es a vuela pluma, sin casi puntuaciones ni separación de párrafos ni correcciones de abundantes faltas de ortografía (casi todos los títulos y puntos aparte y toda la división en capítulos es obra nuestra)» (17, y asegura luego Fray Matías que ha respetado el texto literal, salvo en añadir algunas palabras necesarias gramaticalmente). El editor relaciona la obra con la enseñanza de Santa Teresa y avala su pureza doctrinal y su valor religioso. En 1974 Baldomero Jiménez Duque afirmaba que estos escritos «descubren un alma gratificada con gracias místicas preciosas» (La espiritualidad en el siglo XIX español. Madrid: 1974, 182).

\section{VARGAS Y CERVETO, CARLOS DE}

(Ceuta 1797 - Madrid 1876. Militar carlista. En 1833 se unió a Zumalacárregui e hizo una brillante carrera en el ejército de Don Carlos. En 1839 se opuso a Maroto, que lo detuvo. No aceptó el Convenio de Vergara y emigró a Francia. Amnistiado años después, sirvió hasta 1864 en Cuba y Santo Domingo, de la que fue capitán general. En 1867 es capitán general de las Vascongadas y se opone a la revolución; después se une otra vez a los carlistas.)

—Dos años de campaña de S. A. R. el Sermo. Sr. Infante de España don Gabriel en las Provincias Vascongadas. Memorias secretas de un Jefe carlista desde la llegada de S. A. a las Provincias en noviembre de 1835 hasta que fue separado del mando del Ejército Vasco-Navarro. 
Cita esta obra José María Azcona ${ }^{75}$ : «se conserva manuscrito e inédito en el archivo del marqués de la Lealtad, don Joaquín Elío, en Pamplona, sin nombre de autor, aunque he podido comprobar, por la letra y por otras circunstancias, que es autógrafo de Vargas. [...] En este manuscrito hace alusión a las divergencias entre Zumalacárregui y Mazarrasa [...]. Vargas fue encargado de la defensa del General Elío, defensa que publicó Pirala fragmentariamente y que se conserva íntegra en el archivo citado» $(446)^{76}$.

\section{0. [*465]. VIERA Y CLAVIJO, JOSÉ DE}

— «Notas autobiográficas. Vida y obras de Viera y Clavijo». La Provincia (Las Palmas), 8, 10, 12, 14, 15, 16 y 18-II-1913.

Añado a la ficha original una edición en prensa en 1913 que no tomé en cuenta ${ }^{77}$.

\section{1. [*467]. VILLALOBOS, JOSÉ}

(Militar valenciano. El 2 de mayo, según dice, actuó como enlace entre las autoridades españolas y francesas. Huyó luego y, acusado de traidor, fue encarcelado en Valencia dos meses. De regreso a Madrid, se afrancesó y fue comisario de guerra en Cataluña. En 1813 pasó a Francia; en 1818 aún suplicaba el perdón para volver a España.)

${ }^{75}$ Zumalacárregui. Estudio crítico de las fuentes históricas de su tiempo. Madrid: Instituto de Estudios Políticos, 1946, 446-450.

${ }^{76}$ Sí publicó este otro libro: Mémoires historiques militaires de l'armée basque-navarraise par Charles de Vargas, Officier supérieur de son ...tat-Major Général. Burdeos: 1842. Por lo que sé, es de contenido histórico, no autobiográfico.

${ }^{77}$ Tomo esta noticia de la extensísima ficha dedicada a Viera en la segunda edición ampliada del monumental libro de Agustín Millares Carlo y Manuel Hernández Suárez: Bio-bibliografía de escritores canarios (siglos XVI, XVII y XVIII). Las Palmas: El Museo Canario - CSIC - Cabildo Insular de Gran Canaria, 1975-1992, t. VI, 437-673. Allí se dan detalles bibliográficos más completos de las ediciones que sí recogí en el Catálogo, y se indica que «en la Biblioteca Municipal de Santa Cruz de Tenerife se conservan dos copias manuscritas, una de ellas en el tomo primero de la Colección de las obras inéditas de Don José de Viera y Clavijo» (445). En esa bibliografía de Viera, además, se han vaciado y contrastado las referencias contenidas en las Memorias, lo cual hace que se reproduzcan casi enteras fragmento a fragmento aquí y allá. La autobiografía de Viera es otra de las que estudié en mi citada tesis doctoral. Véase también: Demetrio Castro Alfín. «Viera y Clavijo y la construcción autobiográfica». En José A. Ferrer Benimeli (dir.). El Conde de Aranda y su tiempo. Zaragoza: Institución Fernando el Católico, 2000, t. I, 607-623. 
—Exposición de la conducta pública de Don José Villalobos desde el año de 1807 hasta que se refugió al Reino de Francia en 1813. [Madrid]: [Imprenta de García], 1814 (70pp. $)^{78}$.

Es un típico manifiesto justificativo de afrancesado. Comienza el relato cuando, retirado en Vinaroz por causa de «la situación política de la monarquía española en el año de 1807 y las desgracias que por entonces sufría mi único protector» (1), los sucesos de Aranjuez le hacen regresar a la Corte, pues era partidario del príncipe Fernando. La primera parte del opúsculo se dedica a su conducta el 2 de mayo, vacilando entre su instintivo respeto al orden y la autoridad constituida y su inclinación patriótica. «No es mi ánimo argüir, ni menos atraer a mi opinión a los que siguen la opuesta. [...] Mi objeto es sólo justificar mi conducta desde aquel momento y demostrar que he podido cometer algún error de entendimiento, pero nunca delitos que autoricen a mis conciudadanos a negarme su estimación» (6). Hace un relato muy detallado y con interioridades de lo que ocurrió en el gobierno español ese día y los inmediatos. Luego inserta una «Carta escrita desde Valencia en el mes de agosto de 1808 por Don José Villalobos a Don José Maldonado, ayudante de cazadores de la corona» (15-59). Es un relato patético y quejumbroso, interpelando a su amigo y contándole cuál fue su suerte desde que se separaron. Relata su viaje a Valencia y las vicisitudes que le ocurrieron en medio de la agitación y desorden del país. El eje de su crónica son los atropellos que sufrió, con grave peligro de su vida, encarcelamiento, maltrato e intento de suicidio; sin embargo, en ningún momento concreta por qué todos pensaban que era un traidor. Tras cincuenta días de atroz cautiverio, fue finalmente absuelto. En ese punto es cuando escribe la carta. A partir de la p. 59 sigue el relato para justificar su decisión final de afrancesarse, con humildad a veces y a veces acusando a otros de haber actuado peor.

${ }^{78}$ He consultado el ejemplar que cita Jean-René Aymes (Los españoles en Francia 1808-1814. La deportación bajo el Primer Imperio. Madrid: Siglo XXI, 1987) de la Biblioteca del Palacio Real, serie Varios Impresos, vol. 153, doc. 1. En él no figura pie de imprenta en ningún lado, sólo el año, pero Aymes sí lo indica, mientras que Juan López Tabar lo cambia a: Imprenta de Gracia (Los famosos traidores. Los afrancesados durante la crisis del Antiguo Régimen (1808-1833). Madrid: Biblioteca Nueva, 2001, 73). Es un folleto de formato pequeño. López Tabar afirma que se hizo publicar desde Montpellier y que en 1818 Villalobos insistió desde La Junquera con una nueva representación al rey (AHN, Consejos, 17783). 


\section{2. [*469]. VILLANUEVA Y ESTEGO, JOAQUÍN LORENZO}

—Vida literaria de D. Joaquín Lorenzo Villanueva. Edición, estudio preliminar e índice onomástico por Germán Ramírez Aledón. Alicante: Instituto de Cultura Juan Gil-Albert, Diputación Provincial de Alicante («Espejo de Clío», 10), 1996 (865pp.).

Esta edición incluye un excelente y completo estudio preliminar históricobiográfico, con grandes aportaciones para el conocimiento del escritor valenciano. Ofrece el texto sin modernizar ni anotar, pero íntegro y con un índice onomástico ${ }^{79}$.

\section{3. [*470]. VILLANUEVA Y VIGIL, JOSÉ DE}

(Asturiano, participó en el alzamiento sevillano de 1808 y sirvió empleos de hacienda para el gobierno en esa región.)

—Manifiesto a la nación española de los servicios que hizo durante la dominación francesa el patriota asturiano en Andalucía D. José de Villanueva Vigil y las contestaciones con el señor intendente de esta provincia D. Álvaro Flórez Estrada, por haberle separado de contador subdelegado de rentas nacionales del partido de Marchena. Sevilla: Imprenta del Setabiense, 1814 (72 pp.).

Consulto un ejemplar de este raro opúsculo en la RAH (14/6611, legado Saltillo). El cuerpo del texto se encabeza «A la nación» (3-32) y se fecha en Sevilla, 19-II-1814. Siguen «Documentos justificativos al manifiesto. Cartas que dirigió la Superior Junta de Sevilla desde Ayamonte a su confidente o comisionado en esta capital D. José de Villanueva y Vigil» (33-41) y «Documentos sobre las contestaciones entre el señor intendente de esta provincia don Álvaro Flórez Estrada y el contador subdelegado don José de Villanueva Vigil» (43-72); se fecha esta parte en Sevilla, 19-III-1814. Con un estilo grandilocuente, bastante sobrado de adjetivos y exclamaciones, principia desde el mismo 1808: «corrí presuroso a evitar los males horrendos de la guerra destructora. La convulsión frenética que agitaba a los vencedores y a los vencidos fue para mí un poderoso aliciente que encantó mi alma, me sedujo con poderío y arrastró sin violencia»

${ }^{79}$ Véase mi reseña en Cuadernos de Ilustración y Romanticismo, 6 (1998), 162-165. He dedicado a Villanueva un capítulo de mi tesis doctoral citada, del que se publicó una parte en el artículo: «Autobiografía, Cortes de Cádiz y diálogo humanista: las tertulias constitucionales de la Vida literaria de Joaquín Lorenzo Villanueva». Cuadernos de Ilustración y Romanticismo, 8 (2000), 41-57. 
(4). Dice ser un patriota de la primera hora, que tomó parte en el levantamiento sevillano de 26-V-1808, pero pronto alcanza los comienzos de 1810 , en que los franceses ocuparon Sevilla. Todo su afán es justificar sus acciones durante los años siguientes, según él trabajando para los españoles en la sombra y con encargos específicos del gobierno de Cádiz, casi como un espía en zona ocupada. Cuenta sus idas y venidas, sus hazañas, sus padecimientos, con todo detalle, proclamando lealtad y sacrificio personal: «Cada paso era un riesgo, cada operación un escollo, pero mi alma, superior a toda desventura, no conocía ni riesgos ni precipicios» (17). Esos servicios se duele- no le fueron reconocidos al final de la ocupación. Un segundo eje del opúsculo es su conflicto con Flórez Estrada, que se desarrolla en el segundo apéndice documental, que comienza en agosto de 1813: hubo entre ambos un activo intercambio de escritos acerca de problemas en la administración de rentas y de la destitución de Villanueva. A partir de p. 69 hace un balance de los apéndices, retomando el hilo de la narración, ahora de 1813 en adelante. Ese conflicto es el detonante directo del manifiesto justificativo, que persigue una pronta rehabilitación de sus empleos.

\title{
VILLARÍN, CONDE DE
}

Véase: VALD...S SIERRA, JERÓNIMO

\section{4. [*476; **37]. ZORRILLA Y MORAL, JOSÉ}

\author{
—Recuerdos del tiempo viejo. México: Porrúa («Sepan cuantos», 681), \\ 1998 (XXVIII + 502 pp.). Prólogo de Emilia Pardo Bazán. \\ —Memorias del tiempo mexicano, Pablo Mora y Silvia Salgado (eds.). \\ México: Consejo Nacional para la Cultura y el Arte [CONACULTA], 1998 \\ (219 pp.). \\ —Recuerdos del tiempo viejo. Madrid: Editorial Debate, 2001 (768 pp.).
}

Tres nuevas ediciones de este clásico. 